\title{
A Nation Sings Itself: \\ São Paulo Voices and the Canons of Brazilian Song
}

by

Rachel Chantal Beausoleil-Morrison

A thesis submitted to the Faculty of Graduate and Postdoctoral Affairs in partial fulfillment of the requirements for the degree of

Doctor of Philosophy

in

Cultural Mediations
Carleton University
Ottawa, Ontario

(C) 2017

Rachel Chantal Beausoleil-Morrison 
With loving gratitude to Rhiannon, Amiel and Ian Beausoleil-Morrison. 


\section{Table of Contents}

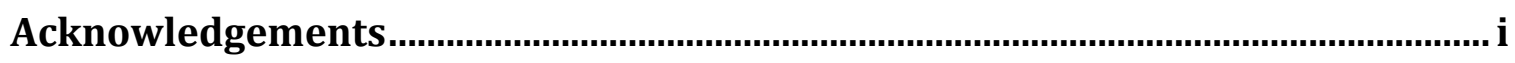

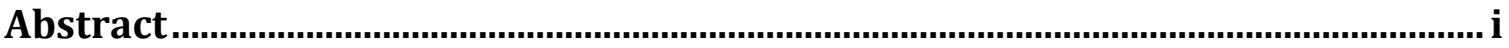

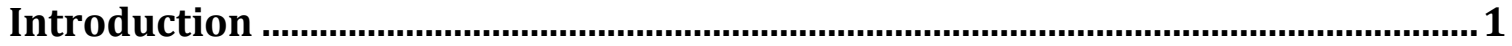

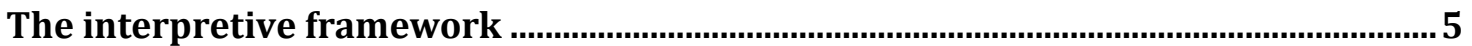

The methodological framework........................................................................................... 7

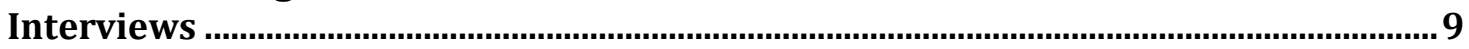

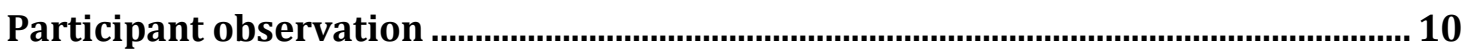

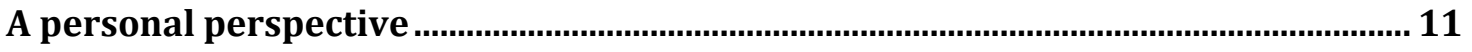

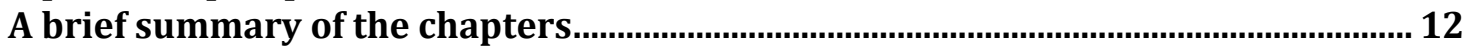

Chapter One: MPB and National Identity .......................................................... 14

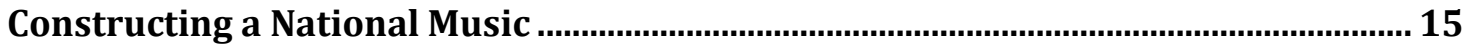

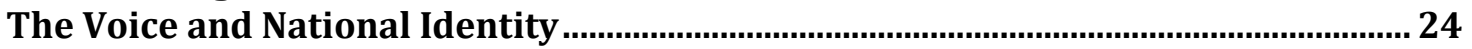

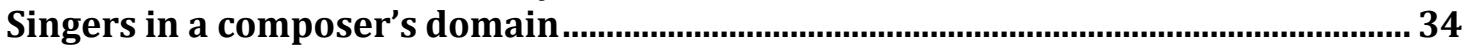

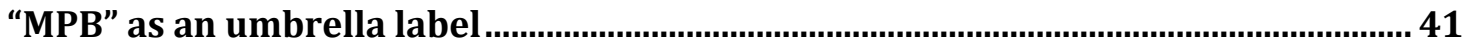

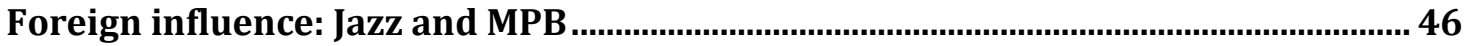

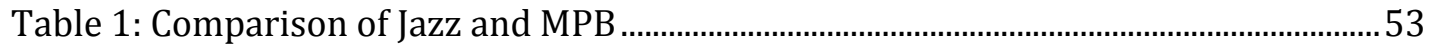

Samba, National Identity and Mestiçagem (Mixture) .................................................. 60

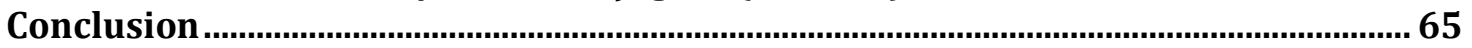

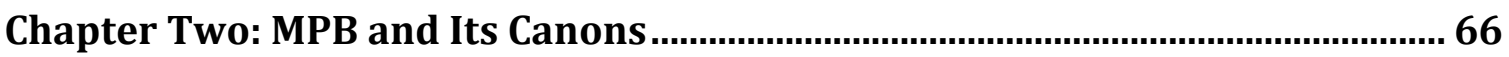

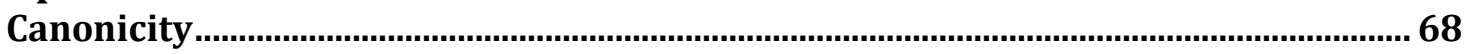

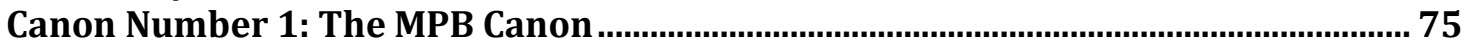

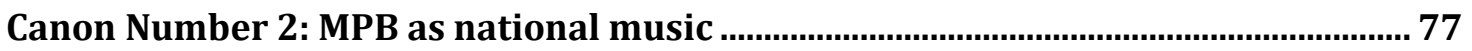

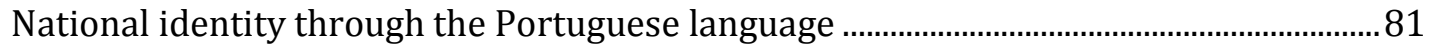

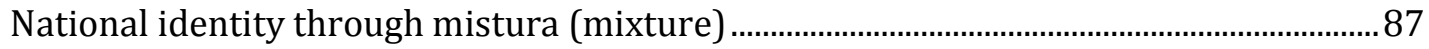

Canon Number 3: MPB as "quasi-popular music" .............................................................. 90

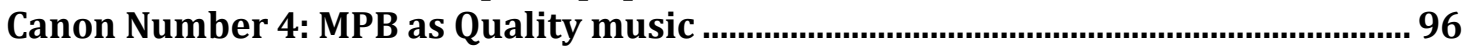

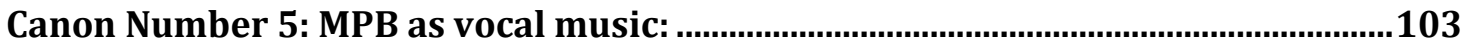

Canon Number 6: MPB as a composer-centred practice ...........................................106

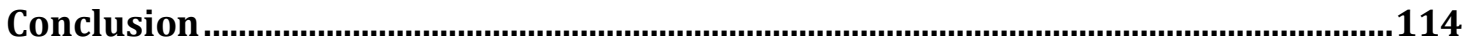

Chapter Three: MPB Pedagogy

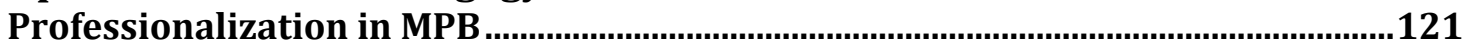

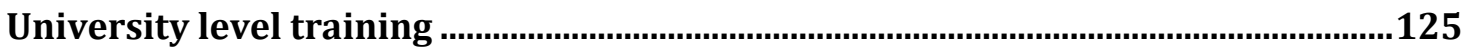

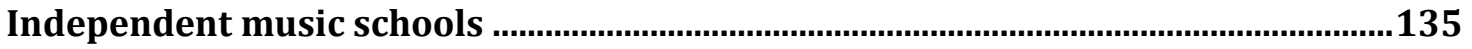

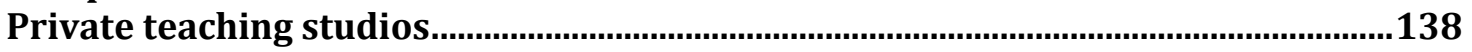

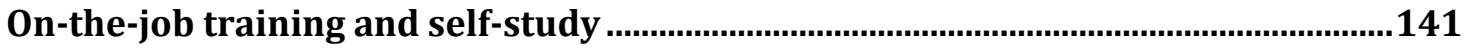

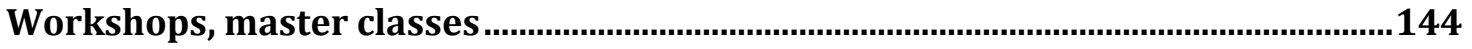

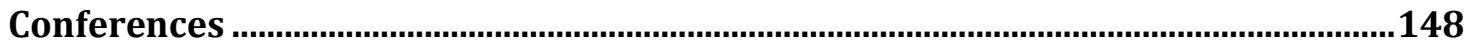

Table 2: Brazilian Singing Before and After Bossa Nova .................................................. 149

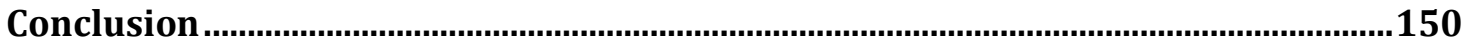

Chapter Four: São Paulo Voices and MPB canons ...............................................155

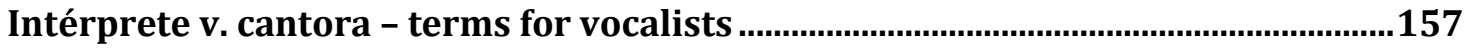

The intérprete in a composer-centred practice ..........................................................161

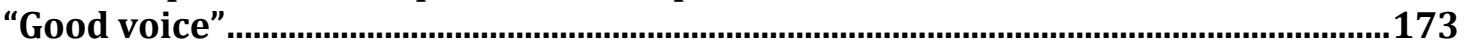




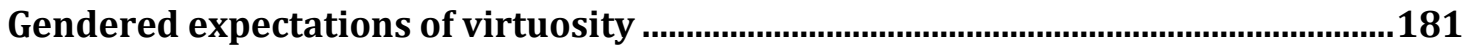

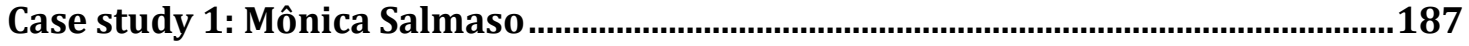

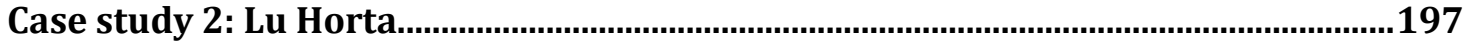

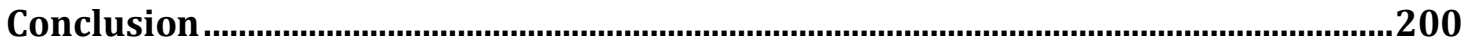

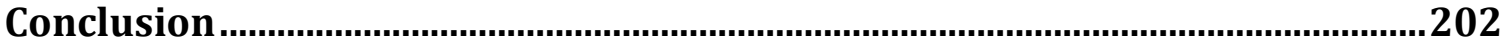

Case study 1: Mônica Salmaso and 'Trem das onze' ................................................209

Case study 2: Fabiana Cozza - Canto Sagrado...................................................................213

Case study 3: "Modinha” as performed by Lívia Nestrovski and Luciana Souza.....216

Case study 4: 'Complexo de épico' as performed by Regina Machado.........................224

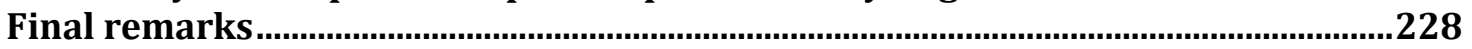

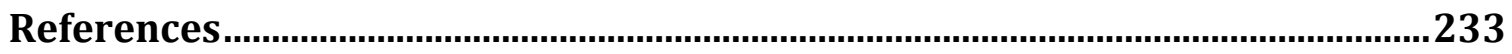




\section{Acknowledgements}

I must begin by thanking my co-supervisors, Professor Sonya Lipsett-Rivera, of Carleton University's History Department, and Professor Lori Burns, of the School of Music at the University of Ottawa. I owe them a debt of gratitude for their strength, knowledge and wisdom. I must also acknowledge some very special mentors: Janet Siltanen, Peter Hodgins, Marie-Ève Carrier-Moisan and Catherine Khordoc.

Eu agradeço aos meus amigos e colegas brasileiros: Evandro Gracelli, Carmen Silvia Fullin, Emilio Martins, Beth Amin, Álvaro Faleiros, Rita Jover-Faleiros, Lu Gallo, Joana Mariz, Marcos Pantaleoni, Lívia Nestrovski, Fred Ferreira, Regina Machado, Izábel Padovani, Irajá Pinto de Menezes, os músicos do projeto Panamérica Canção, os membros do VocalSP, Mônica Salmaso, Rosa Passos e Leny Andrade. Eu estou muito grata pelo tempo que passaram comigo, pelas discussões apaixonadas, pela música, pela sua hospitalidade e generosidade.

Several people have been a constant source of support throughout this entire process. I wish to thank Elise Letourneau, Pauline Comeau, Marie-Hélène Pichette, and Michaela Kreim. I am extremely grateful to my cohort, Johnny Alam, Joana Pimentel, Jenna Stidwill, David Richler and Lisa Truong. I could not have asked for a stronger team!

I can never repay the support I have received from my parents, Nola Lauzon and Raymond Beausoleil; my sister, Elise Beausoleil; and my mum-in-love Lena Morrison. Je remercie particulièrement mes enfants, Amiel et Rhiannon BeausoleilMorrison, qui ont su m'aider à gérer la maisonnée, et patienter lorsque je n'étais pas disponible. Votre appui m'a aidé à terminer le projet etj'en suis très reconnaissante et fière.

Finally, I must thank my husband, Ian Beausoleil-Morrison, for being my brilliant champion, and for pulling the heroic act of seeing me through this journey of self-discovery and fulfillment. Your arms are a place of safety, respect, confidence and understanding, for which I am eternally grateful. 


\section{Abstract}

\section{A Nation Sings Itself: São Paulo voices and the canons of Brazilian song}

Música popular brasileira (or MPB) is a category of music that holds a particular stature in Brazilian culture, between pop and classical. Although the criteria and definition of MPB have changed since the first use of the term in the 1960s, there nevertheless remains a set of core values that pertain to this music. MPB is foremost a national category of urban popular music that is said to be 'of quality' (i.e. has artistic value), and not primarily motivated by commercial interests. It includes many genres and musical movements, most of which consist of singing with accompaniment; for instance bossa nova, samba, jovem guarda (young guard), Vanguarda paulista (São Paulo Vanguard) can now all be considered MPB. This dissertation focuses on the intérpretes, or the vocal component, of the composercentred practice of MPB, addressing questions of subjectivity and authorship. This leads us to examine pertinent issues that permeate the topic, such as gendering, racialization and class distinctions. A vast majority of singers in MPB are women, while composers are mostly men. Focusing on the lead singing role affords us the opportunity to highlight the creative input of intérpretes, as co-creators in the realm of Brazilian song, and to explore the ways in which the Canon of Brazilian popular music is constructed. It also allows us to call attention to the criteria, or canons, that comprise this music. This interdisciplinary ethnographic study of São Paulo MPB singers shows that there is no singular 'way' that can be called 'Brazilian singing', but rather ways that are associated with different cultural groups within Brazil. The roles in MPB are largely siloed along gendered and racialized lines. My analysis concludes that MPB is a middle-brow concert music that is mapped as national, providing a symbol of national identity that is passed to subsequent generations via various canonizing forces, especially the educational system. 


\section{Introduction}

Studying Brazilian popular music has been a very humbling experience. This vast repertoire looms too large to absorb, much less to comment on from the point of view of someone who did not grow up surrounded by its sounds. I vacillate between feeling small and being in complete awe of this music and its creators. I take this word "creators" to include both performers and composers. Both are required to make music. My dissertation turns the spotlight on the female artists who voice the sounds imagined by the composers of Música popular brasileira (Brazilian popular music, hereafter MPB).

This study examines the aesthetics of the female voice in MPB in Brazil's largest city, São Paulo, and the position that women occupy in this music, primarily as vocal performers, or intérpretes, and rarely as composers or instrumentalists. MPB is widely considered by Brazilians to be their "quality" popular music (Stroud 2008) through which participants gain prestige as both musicians and audience members. An overwhelming majority of MPB intérpretes today are women, yet credit for innovation in Brazil's most highly regarded popular music practice is more often than not directed to composers and lyricists, the great majority of whom are men. When asked to name artists who define MPB, scholars and practitioners point invariably to what I may call the "ineluctables"; the names that surge as signifiers of the canons of Brazilian popular music, both at home and on the international stage. A typical list may read as follows: Maria Bethânia, Chico Buarque, Gal Costa, Gilberto Gil, João Gilberto, Tom Jobim, Vinicius de Moraes, 
Milton Nascimento, Elis Regina, and Caetano Veloso ${ }^{1}$. Although many other names can be added to the list, one thing remains consistent: the men are by and large authors, innovators and instrumentalists as well as singers, and the women are usually strictly vocalists. And while the women on this list are revered for the sound of their voice and their interpretation of Brazilian songs, they are not attributed the same kind of authority as their male composer counterparts. In this study, my goal is to explore the MPB Canon, its principle criteria (or canons), and the role of the intérprete within them. I examine vocal aesthetics in MPB and bring attention to the constraints and contributions of female voices to a body of music that, by its very name, is said to represent a nation. São Paulo provides a rich terrain of information for this case study, with a vocal pedagogy and performance community that is highly active in the development and dissemination of what its members refer to as "Brazilian singing."

The presence and prominence of women as MPB vocalists points to numerous questions, especially in relation to authorship and identity. For instance, what are the implications for female musicians when they have so often been confined to the role of intérprete-interpreters of other people's compositions, to the exclusion of all other aspects of the music — such as playing instruments, composing and song writing? Why are innovations in vocal style given less respect than those made in typically more male-dominated musical domains such as composition, lyric writing, or instrumental performance? What demands for vocal technique and production exist that might privilege certain kinds of voices over

${ }^{1}$ I have placed these names in alphabetical order to avoid imposing my own biases of relative importance. 
others? And most importantly, who sings the nation? In other words, who represents the nation in song? Asking these questions allows us to examine the intimate connections between the popular singing voice and national identity construction, and all its entanglements with gendering, racialization and class distinctions.

Ethnomusicologist Jennifer Post (1994) has argued that the most common avenue of musical expression for female musicians the world over is the singing voice. In many cultures, singing has been one of the most important ways in which women have participated in music making. Post attributes this tendency to the traditionally domestic roles assigned to women, encouraging cost-free music for private consumption that allowed hands to be busy with chores $(1994,38)$. The voice has been theorized as gendered sound in various musical spheres, such as opera (McClary 1991, Abbate 1993, Wood [1994] 2006), pop rock (Frith 1996, Burns and Lafrance 2002, Burns 2010), and jazz (Dahl [1984] 1996; Rustin and Tucker (2008)). My study examines the very positioning of women in MPB primarily as singers, and how their participation in the creation of national identity through their vocal sound has been circumscribed by that role.

Brazil has long been home to numerous accomplished cantores e cantoras (male and female singers) who could be said to have formed a canon of their own. Within MPB singing, there exist various ways of sounding that link the singer with an established lineage of vocalists who have defined a particular branch of MPB vocal sound, and with a repertoire that is accepted as Brazil's quality music (Machado 2012, 21). Though musical creativity is often equated with the 
compositional process, MPB singers are expected to interpret songs in a unique way, making each song "their own." This process occurs outside the realm of the written form, and is generally undervalued in relation to the authorship ascribed to composers and lyricists. By examining the various styles that qualify as MPB singing, according to São Paulo MPB musicians and pedagogues, this case study sheds light on some of the forces that drive particular vocal aesthetics associated with MPB. It also helps to underline the contributions women have made to MPB. The dissertation focuses on performance practice and pedagogy in São Paulo, which is the often-overlooked "other" centre of what is known as the Rio-São Paulo axis of nationalized cultural production. While Rio de Janeiro is often cited as the centre of national culture, numerous MPB singers are, in fact, based in São Paulo. The region of São Paulo is the home of some of the most prestigious university popular music programs in the country, namely that of the University of São Paulo (USP) and the University of Campinas (UniCamp), and Faculdade Santa Marcelina. As the country's largest metropolis, São Paulo hosts numerous musical scenes. My focus on the MPB vocal performance and teaching community in no way minimizes the multiplicity and porous nature of musical life in São Paulo, or of Brazil as a whole.

In the literature on Brazilian popular music in particular, many scholars have elaborated the discussion of racialized musical practices in relation to genres that have gained regional or national status (Moehn 2007, Packman 2009 and 2011, Sharp 2011, Rocha 2012, Burdick 2013). And while some of them refer to sex/gender questions in their studies, the relationship of sex/gender and national identities is mostly left understudied, and under-theorized. Given the evidently 
gendered roles in MPB, I am left wondering whose voice is truly represented in this music that holds such high status as the nation's "quality" popular music (Stroud 2008). As Cavarero puts it: "Feminized from the start, the vocal aspect of speech and, furthermore, of song appear together as antagonistic elements in a rational, masculine sphere that centers itself, instead, on the semantic. To put it formulaically: woman sings, man thinks" $(2005,6)$. On the surface, this remark would seem to summarize the relationship between vocal interpreters and composer-singer-songwriters. I will delve into this question and explore how it relates to the discourse of interlocutors who participate in MPB in a variety of capacities. The stakes for singing in Brazilian popular music are especially high since it has been largely dominated by vocals, except in few specific genres in its history. This makes the lack of specific attention to the voice in much scholarship particularly conspicuous. I suggest that the voice, which is so ubiquitous in this music, has been taken for granted in studies on Brazilian popular music.

\section{The interpretive framework}

The guiding framework for this study is a theory of canonicity, which builds on the work I began in my Master's thesis on Montreal jazz vocalists. The main premise of this theory is the following: “... by 'canon,' I mean not only a set of norms represented by a few individuals, but the norms themselves" (Beausoleil-Morrison 1999, 9). My understanding of canons owes a great deal to the work of Carys Wyn Jones (2008), Marcia Citron (1993), and Anne Karppinen (2016). Each of these scholars has, in the musical domains of rock and Western classical music, discussed 
agency and values in relation to canons in ways that are very much applicable to MPB. Framing MPB in terms of its canons, rather than as a genre, offers the possibility to highlight the political, ideological and unfixed nature of its construction, and a deeper understanding of the vast array of genres it actually comprises. MPB canons clarify many paradoxes inherent in this music. A theoretical framework of canons draws attention to the implications of their application, and the very practical results of their hold on the public imaginary. In other words, who gets "admitted" as an MPB artist depends greatly on their ability to conform to its canons.

Bossa Nova remains a cornerstone genre under the MPB umbrella. Its vocal sound is an important marker of "Brazilianness," an identity constructed first and foremost upon the concept of mestiçagem - the mixture of European, Indigenous, and importantly, African "races" and cultures—which is said to have been bolstered by Gilberto Freyre's influential treatise on Brazilian society "Casa Grande e Senzala" (The Masters and the Slaves) of 1933. This work explicitly linked Brazilian nationality with mestiçagem (racialized mixture) (Dunn 2001, 24; McCann 2004, 77). Anthropologist Hermano Vianna emphasizes the importance of Freyre's project, and its long-standing effects in defining national identity, despite being highly contested ([1995] 1999, 116). Tensions related to mestiçagem, and questions of authorship are explored by Jeff Packman in his article "Signifying Salvador" (2009). Packman elaborates on local manifestations of Henry Louis Gates's concept of Signifyin(g) (Gates 1988), showing how Bahian musicians engage in musical dialogue that crosses genres, authors, time, geographical space, and class. Packman 
highlights the importance of discourse that creates and sustains a particular understanding of music and society, in which variation, or what Gates might call repetition with signal difference, is a key element. Nevertheless, Packman counterbalances Signifyin(g) with the importance of musical authors, in Bahia. He states: “... the rereading of music by professional musicians in Salvador creates a tension, albeit a productive one, between Signifyin(g) and authorship as both work together to inform popular music performance" (Packman 2009, 108). In applying it to the São Paulo MPB performance scene, an adapted notion of Gates's principle of Signifyin(g), one that treats it as hybridized, and entangled with lingering Eurocentrism in Brazil, helps me reflect upon the vocal means by which female singers signify in MPB songs to construct a sound of Brazilianness, and how their authority in this regard is entangled with constructions of gender, and its intersections with racialization and class distinctions.

\section{The methodological framework}

The fieldwork for this study was conducted both on site and from a distance. I traveled three times to Brazil between 2012 and 2015, for a total of ten weeks, spending my time in the São Paulo-Rio corridor. Every effort was made to maximize experiences there, to take advantage of contacts' visits to Canada, and to maintain relationships via long-distance communications in between. This study, which contributes on both theoretical and ethnographical levels, attempts to balance the requirement for fieldwork with interdisciplinary analytical tools. While in Brazil, I conducted detailed ethnographic interviews with selected artists, pedagogues and 
speech pathologists. The selection of interlocutors was made mainly through a professional network of musicians that began developing as a result of my collaboration, in Ottawa, with a Brazilian guitarist and co-composer by the name of Evandro Gracelli. After Gracelli's return to São Paulo in 2011, I was invited to go there to perform, teach and give lecture-recitals. This lead to several contacts being made in the São Paulo MPB community, many of which produced a deep well of information, as well as further musical partnerships, and valuable friendships. Also as a result of these contacts, I was invited to participate in the Panamérica Canção (Panamerican Song) Project, funded by the University of São Paulo (USP), and lead by musician and professor of French letters, Álvaro Faleiros in partnership with Carleton University in Ottawa. This cultural exchange allowed me to invite eight musicians and a co-producer to Ottawa with the purpose of giving workshops, lecture-recitals and master classes in Brazilian music for students in the Ottawa region. Additionally, we produced a public concert, in which I participated as vocalist in one of three featured ensembles. In return, I was invited back to São Paulo the same year to provide the Paulistana ${ }^{2}$ community with a taste of French Canadian music. This exchange provided several opportunities in both countries for informal discussions and music making that informed this study.

\footnotetext{
2 'Paulistana' describes inhabitants of the city of São Paulo.
} 


\section{Interviews}

In Brazil, I conducted lengthy formal interviews with eight individuals, some over the course of several days. Four of these interlocutors consider themselves primarily intérpretes in their performance sphere: Joana Mariz, Lívia Nestrovski, Regina Machado and Izábel Padovani. All of these women also teach in various public and private settings. I interviewed Beth Amin, Álvaro Faleiros, Evandro Gracelli, who are cantautores (singer-composers), and Irajá Menezes, a Brazilian popular music educator who sings and plays guitar as his main mode of teaching. Amin is also a trained speech pathologist who studied at Berklee College of Music, in Boston, Massachussetts. I also took advantage of a visit to Ottawa by Luciana Horta, an active singer, body percussionist, guitarist and composer from São Paulo who was visiting Ottawa in the spring of 2016. I assisted in her sound check for a concert she was giving in Ottawa, attended her show, and conducted a formal follow-up interview with her the next day. Additionally, she provided a body percussion workshop to my local vocal ensemble. In the course of this study, I did not meet any men who are strictly or primarily solo intérpretes.

Finally, Joana Mariz invited me to conduct an invaluable, extended group interview with VocalSP, which is an association of vocal professionals from the São Paulo region, including singers, teachers and speech pathologists. All interviews were recorded as audio files, and subsequently transcribed, with the blessing of interlocutors. Throughout the dissertation, comments by interlocutors are woven into the text wherever appropriate. I have included these in the original language in 
which the interview was given, to preserve the intended meaning. English translations follow all Portuguese locutions.

\section{Participant observation}

Both in Brazil and in Ottawa, I attended many concerts, lecture-recitals, and vocal master classes on Brazilian popular singing, percussion, MPB history and classical singing. In São Paulo, I was invited to observe a rehearsal by MPB group Canto ma non presto, led by Joana Mariz. I observed full days of private voice lessons given by Amin and Mariz. I attended final MPB vocal final exam juries at Faculdade Santa Marcelina, an important São Paulo university vocal program where Mariz and Nestrovski were both teaching. I participated as a vocalist in a three-evening master class on samba, bossa nova and balada (ballad) singing, given by MPB icon Rosa Passos, in São Paulo. This session was recorded in its entirety, a practice that was not only accepted, but encouraged by participants. I took voice lessons in São Paulo from Beth Amin, and in Rio de Janeiro from Lívia Nestrovski and her guitarist partner Fred Fereira, receiving their informative feedback on bossa nova style singing. Once again these sessions were recorded for subsequent analysis. Finally, I wrote a song lyric in Portuguese, and asked for the help of Álvaro Faleiros, lyricist and professor at USP, to correct and modify it as needed. This exercise gave me unexpected, yet valuable insight into the poetic aesthetics of MPB. 


\section{A personal perspective}

As a vocalist, songwriter and pedagogue myself, I conducted several private lessons, master classes, lecture recitals and a choir rehearsal in São Paulo, some of which were accompanied by Evandro Gracelli. These took place at a variety of institutions, from private music schools to the largest university in South America, USP. These gave me a feel for some of the vocal concerns brought to the table by students of singing in the São Paulo region. Gracelli and I, often accompanied by other musicians (guitarists, bassists, percussionists), performed in several shows, at bar venues in an around São Paulo, and toured the São Paulo region with the Panamérica Canção project. Finally, Gracelli and I did a studio recording of our co-authored original songs. All of these experiences, and the informal exchanges that took place, were learning opportunities for me and added a great deal to my understanding of MPB.

On a personal note, I am a French Canadian female vocalist with a background in classical voice technique. My performance career has combined classical, jazz and popular styles. I have been teaching voice for over 18 years. As I have been a participant, as well as an observer of the São Paulo music scene, I occupy both insider and outsider perspectives. While I cannot deny bringing my musical and personal experience to bear on this study, it is my hope that the benefit of being simultaneously an insider and an outsider will outweigh the difficulties. I am extremely grateful to my Brazilian interlocutors and colleagues for allowing me to enter into this conversation with them, and I pledge that I have applied as much intellectual honesty as I can to the task. 


\section{A brief summary of the chapters}

All chapters carry the thread of gendered musical roles and examine the implications of these roles, how they are engrained in the canons, and maintained and reproduced through performance and pedagogical practices. In the first chapter, I examine musical nationalism in Brazil within the broader context of Latin American national musics. I give a brief overview of the history of música popular brasileira (MPB), with particular attention to singers, over the course of the $20^{\text {th }}$ century. I also discuss the relationship between MPB and the United States national music, jazz (Beausoleil-Morrison 1999). This section attempts to shed light on the ambivalence toward foreign influence in Brazilian musics.

In the second chapter, I outline my understanding of the established canons of MPB, and examine some of the means by which they have become entrenched. In particular, I give close attention to the various streams of MPB singing that have come out of these canons and continue to influence singers of today in São Paulo. These streams reproduce, and align with, racialized musical categories. I discuss the idea of MPB as Brazil's "quality popular music" and its place in the scheme of low- to high-brow music.

The third chapter focuses on vocal pedagogy as the primary means by which canons are transmitted to following generations of singers. I outline the various training grounds available to singers of MPB, including on-the-job training, applied (mostly private) music lessons, and institutional programs such as the one at Faculdade Santa Marcelina. I discuss the gradual professionalization of MPB vocalists over time. 
The fourth chapter puts the spotlight on Paulistana singers and the issues they face as the lead performers in a composer-centred practice. I discuss the meanings and implications of the various terms used to denote the singer in MPB. I analyse the prevailing discourse by and about Brazilian singers and the idealized MPB voice. This chapter shows some of the strategies employed by singers to respond to the canons of MPB, either to gain admittance to them, or to disrupt them.

The concluding chapter consists of short vignettes, or case studies, involving five currently active singers from the São Paulo region: Mônica Salmaso, Fabiana Cozza, Lívia Nestrovski, Luciana Souza and Regina Machado. These vignettes help to trace the thread between the preceding chapters, drawing particular attention to four overarching principles that govern MPB, namely: art value; the composer and the composition; virtuosity; and authenticity. Applying these principles to each performer reveals a certain continuity in what may appear at first as a very disparate musical category of Brazilian popular song. These vignettes whet the appetite for further study into each of these cases. 


\section{Chapter One: MPB and National Identity}

"The girl from Ipanema goes walking," and travels all around the globe as a symbol of Brazilian culture. Initially made famous by João Gilberto, the "father" of bossa nova singing, and his wife, Astrud Gilberto, this song is one of many bossa nova favourites that graced the world with a new sound of Brazil in the late 1950s and early 1960s. This sound would eventually come to dominate a category of music by the name of Música popular brasileira, or MPB. The musical category that invokes the nation carries tremendous weight despite-or perhaps because of-its commercially inferior status. In order to understand how MPB gets positioned as a national music, and become "a música que nos identifica" (the music that identifies us) (Joana Mariz, Group interview with VocalSP, June 27, 2015), we must take a step back and examine the ways in which this phenomenon has occurred throughout Latin America.

This chapter aims to put into relief the importance of popular music in the formation of national identity, and the particular importance of national identity in Brazilian culture. A focus on the voice and vocalists within the MPB context brings issues of gendering, racialization and class differentiation to the surface. On these issues, I will bring into dialogue scholars in the often-overlapping spheres of anthropology, ethnomusicology, musicology, history, literature, political science, cultural studies, popular music studies, Latin American studies, international relations, transnationalism, women's studies and communications. My intention is to provide the background necessary for a discussion of MPB canons in the following chapters. 


\section{Constructing a National Music}

Cultural historian John Chasteen points out that by the 1930s, many Latin American countries had a national rhythm, and importantly, that music and dance are inseparable in those musical cultures (2004). The processes by which national musics are constructed feature salient forces. For instance, the following authors discuss government intervention strategies aimed at nationalizing particular musical genres to invigorate a sense of national unity: ethnomusicologists Falina Enriquez (2012), Ketty Wong (2011), John O'Flynn (2007), Thomas Turino (2003), Peter Manuel (2000); Latin American studies expert Robert Neustadt (2011); musicologist Egberto Bermúdez Cujar (2008); anthropologist Hermano Vianna ([1995] 1999). These authors demonstrate how much national governments have at stake in the modeling (in both the reflexive and constitutive sense) of national identity through popular music. In other words, governments in power have used popular music as a means to shore up support of the people and create a sense of national unity.

Government interests cannot reduce to the level of the banal the importance of national identity. To quote Richard Morse: "[Identity] starts with tacit selfrecognition" (cited in Béhague 2000, 22). Ethnomusicologist Gerard Béhague adds: "What seems particularly relevant, therefore, is the articulation of the relationship between music and the various contexts of identity (self-recognition) construction" 2000,22 ). If the propaganda works, one has to think there is a thirst among citizens to feel a sense of national belonging. The lengths to which Latin American state 
powers have gone to support the creation of national musics highlight the power of popular music in the construction of that identity.

Other forces, such as modernization through urbanization and technological advancement, as well as industrial and commercial interests, are also at play in the construction of national musics (Vianna [1995] 1999), Bermúdez 2008, Frota 2000). As we will see, all of these forces come into play in the contested field of national musics. To understand how certain musics get mapped nationally, we must first examine the nation as a level of identity.

Many ethnomusicologists and popular music scholars (e.g. Waxer 2002, Galinsky 2002, Guilbault 2006, Party 2008) have examined cases in which the nation is bypassed in favour of local, regional or hemispheric levels of identity. As part of the postnational ${ }^{3}$ debate, the focus shifts from the national to the relationship between the local and the global. Roland Robertson coined the term "glocal" in 1995, meaning "the tendency for world cultures to operate through the interpenetration of local and global networks" (Biddle and Knights 2007, 5).

Latin American literature specialist Ignacio Corona, and musicologist Alejandro Madrid-González, put forward a framework of musical identities based on the postnational, as a way of understanding the impact of globalization on contemporary culture. They describe the postnational perspective as a "point of view beyond the nation-state as the frame of reference" $(2008,3)$. They maintain that the postnational does not negate the existence of the nation-state, but they call into question the latter's ability to serve and protect its citizens, particularly the

\footnotetext{
${ }^{3}$ I have adopted the spelling used by Corona and Madrid (2008).
} 
underprivileged $(2008,4)$. They believe that music is important in the examination of postnationality because of the ease with which it travels $(2008,5)$.

If identities are unstable, continuously-changing processes, we must understand the fixed character of nationalist music historiography as well as their music canons as essentialist discourses that support larger nationalist and often colonialist projects $(2008,7)$.

Corona and Madrid posit that national boundaries "are increasingly insufficient to locate national or local cultures", and that "authentic" musics can no longer be assumed to be produced, played, consumed, in local spaces by local people $(2008,8)$. Although "local" is a relative term, Corona and Madrid indicate: "The importance of the city is a key development of postnational, in particular the large metropolitan centers of the Western world, which now function as the new hubs of world music production" $(2008,17)$.

I have noted that between the national and the postnational, the local-global binary remains inadequate to explain the complexity of fields of identity at work in musical communities. Cities certainly become the main focus in relation to regions within nation-states, and to the nation-state itself, or to groups of nation-states, and to what are often referred to as global identities, or what I think of as "panidentities," such as the pan-Latino identity. That said, my experience in São Paulo suggests that national identity is very much alive in the MPB community there. In fact, the frequency with which Brazilian identity is invoked in everyday conversation as a driving force for everything from personal to institutional behaviours, is one of the features that provoked my interest in this topic. 
I will now proceed to highlight the writings of several scholars from a variety of disciplines who have found that the nation remains one of the most important bases upon which Latin American peoples identify themselves. The most oft-quoted source on the subject is political scientist and historian Benedict Anderson's Imagined Communities ([1983] 2006), so much so that the concept is often referred to without citation (for instance in Bruner 2002, Biddle and Knights 2007, Corona and Madrid 2008), as it seems to have passed into common parlance. Anderson believes that nation is experienced as naturally as family, evidenced by the fact that people are willing to die for it (Anderson [1983] 2006, 144). He argues that print media was a source of nation building in the Americas since its appearance in the late $18^{\text {th }}$ century, in that it gave masses of people access to the same information, particularly in regards to a shared homeland. In her study of Bolivian indigenous music, anthropologist Michelle Bigenho extends Anderson's visual notion of imagined communities to sound and motion. She states:

If Anderson wrote about nations that read common texts, I want to lay out a nation that listens to, dances, and feels an imagined common bond, and that plays and dances, for itself and for others, the elements of the feelingful activities that bind people who do not necessarily know each other (Bigenho, 2002, 3).

In contrast with the view of Anderson, some scholars are critical of his theory stating that it does not bear close scrutiny, albeit a very helpful and enduring concept. Chasteen says that Anderson's concept itself has had a great deal of impact, and will continue to do so, but that it requires qualification and further elaboration. For instance, Chasteen explains that construction of national sentiment in Latin America came after independence, not before (Castro-Klaren and Chasteen 2003, 
xviii). He also notes that the term "nation" was applied to various groups of slaves coming from the same port of origin $(2003, x i)$. Furthermore, miscegenation confounded any caste system in colonial Americas (2003, xiii).

Chasteen also talks about strong provincial identities throughout Latin America in the 19th century $(2003$, xiv). He explains that nativism became a political gathering force that actually propelled independence. Once independence was achieved, nation-states used the idea of cultural affinity to define nation for the purposes of exclusion and inclusion (2003, xvi). He states: "Gradually, the wars of independence and their heroes became important reference points in the imaginative construction of new nationhood" (2003, xvii). He adds:

Spanish American and Brazilian nationalists have continued, ever after, to elaborate nativist themes in everything from history, poetry, and fiction, to music and folk dance movements. The systematic designation of "typical" dishes and peasant costumes, for example, the energy invested in them, and the pride with which they are displayed to foreigners, go far beyond analogous activities in the United States. (2003, xviii).

These thoughts support my own observations from contact with Brazilian people both in their homes and in mine. The frequency with which the country is named in conversation was one of the first indicators to me that national identity is of particular importance to them. My initial awareness of this factor keenly contrasted against my own self-effacing Canadian culture. When I presented one of my own recordings as a gift to singer Lívia Nestrovski, her first question was "What songs are Canadian on this disc?" I realized, not without some shame, that not only did I not know the answer immediately, but only one track on my entire album is by a Canadian 
author, me. Her surprise and disappointment were clear, and spoke volumes about the value she places on national content.

Other scholars, such as musicologist Ian Biddle and Latin American and women's studies expert Vanessa Knights state their intention to reinsert the national into the postnational debate, as a middle ground between the local and the global $(2007,6)$. They view popular music as the boundary-crossing cultural practice par excellence, and stating that "...globalization cannot be unproblematically equated with homogenization" $(2007,7)$. In their view, popular music, in most of the world, “...outside the small Anglo-American territories," has always been politically charged $(2007,9)$. They observe: “Thus, we should not be surprised to find that new forms of nationalism continue to emerge and the force of the nation as a cultural trope continues to adapt to new political and material conditions" (Biddle and Knights 2007, 11). Latin America literature scholar Idelber Avelar and LusoBrazilian cultural politics expert Christopher Dunn seem to agree when they state: "Our premise is that the construction of citizenship in all of its dimensions takes place primarily within national boundaries even as it is informed by international and postnational discourses and practices" $(2011,7)$.

Political scientist John Coakley highlights that histories are written by those in power to both legitimate and maintain that power $(2012,115)$. Further in his discussion of music and nationalism, he emphasizes songs and operas as conveyors of messages of national identity mainly through lyrics $(2012,127)$. For his part, communications specialist Micheal Lane Bruner argues that national identity is an “ongoing rhetorical process" $(2002,7)$. He describes his approach as “...designed, 
not to uncover the identity of a nation, but to analyze moments in time when competing articulations collide in the ongoing discursive negotiation of what it imaginatively means to be a member of a nation" (2002, 7, emphasis in original).

As Anderson notes in the case of Ukraine, language can be decisive in formation of national consciousness ([1983] 2006, 74). He explains that using the vocabulary of kinship, print media was able to construct, for the "reading class," a connection based on nationality, as people were able to access the same information whether they knew each other personally or not ([1983] 2006, 144). In the same order of thought applied to the underclass, popular music studies and Brazilian literature specialist Wander Nunes Frota examines the samba as a national symbol. He explores radio, the sound equivalent of print media, as an education tool for the illiterate (Frota 2000, 13). Luso-Brazilian literature and cultural expert Charles Perrone, and Christopher Dunn, remind us that during Brazil's Vargas regime from the 1930 s to the $1950 \mathrm{~s}:$

National music was instrumental in the plan to win over listeners in Brazil and abroad. In a public pronouncement, the director of the state radio operation asserted: "It is the voice of Brazil that will speak to the world, to tell civilized peoples of the universe what is being done here for the benefit of civilization." $(2001,12)$

The image of Brazil on the world stage is a key motivator for the development of a strong national music canon, one that puts Brazil's "best foot forward" and offers its citizens a sense of pride and dignity. As I will discuss in Chapter Two, the creation of a canon of "música boa" (good music) is key in the positioning of MPB on a national scale, in a global context. 
In his book The Mystery of Samba, Vianna outlines how technological, political and artistic elements converged in the 1930 s to solidify Carioca ${ }^{4}$ samba's role as the national music of Brazil. Recording and broadcasting (radio) technologies reached a mass audience at this time. The 1930 revolution led to the authoritarian government of Getúlio Vargas taking power. Vargas implemented the mandatory radio program known as "Hora do Brazil" (The Hour of Brazil) (Vianna [1995] 1999), 77), which highlighted government executive decisions of each day at seven o'clock. The programme name was altered in 1962, interestingly, to "A voz do Brasil" (The Voice of Brazil) and continues to air to this day, even though it has a slightly more flexible daily schedule since 2010 (Silveira, 2010).

Vianna shows that from the mid-1800s to 1930 s, carnival music was varied, including polkas, waltzes, mazurkas, schottisches, tangos, American Charlestons and fox-trots, Brazilian maxixes, modas, marchas, cateretês, and desafios sertanejos. Vianna adds:

... none of [those dances] coming close to contemporary samba's total domination of the festival, none of them considered to be a "national rhythm". ... Only in the 1930s did Carioca samba "colonize" Brazilian carnival and become a national symbol. Thereafter, samba would be considered representative of the nation, while other Brazilian musical genres would be considered merely regional styles. (Vianna [1995] 1999), 78)

In 1937, the Vargas regime imposed a requirement that samba schools, which were responsible for carnival music, "dramatize historical, didactic, or patriotic themes" (Vianna [1995] 1999, 90).

\footnotetext{
${ }^{4}$ Carioca is a qualifier that means 'from Rio-de-Janeiro.'
} 
Cultural historian Darien Davis echoes Vianna's views on the impact of the Vargas regime: "Thus, with the support of many other artists and intellectuals, Vargas began a national integration policy that sought to forge a greater sense of national identity among the all-too-independent states of Brazil” (2012 (2000), 179). Avelar and Dunn concur, stating that despite his "legacy of authoritarianism and clientelism," Vargas also left behind a profound sense of unity based upon Brazilian national identity that is still strongly felt to this day $(2011,12)$. Avelar and Dunn further explain:

The Vargas years represented a historical watershed that would have profound and lasting impact on Brazilian political, social, and cultural life. The now familiar notions of national identity, popular culture, the povo (people), and brasilidade (Brazilianness) remain central, albeit contested, terms in the national discussion. It was also during this period that the analytic category and commercial moniker "popular music" began to circulate to refer to massmediated urban music as opposed to rural folklore. $(2011,17)$

Though samba was actively cultivated as the national rhythm, the seeds of MPB as we understand it today, were being sown in the juxtaposition of urban popular music and samba. Perrone and Dunn emphasize how national unity was tied to modernism in 1930s Brazil, when the notion of brasilidade [Brazilianness] took root. They explain:

[Brasilidade] found extensive artistic expression and functioned as an ideology of national identity transcending differences of class, race, and region... Since this period, samba has been instrinsically associated with brasilidade" $(2001,11)$.

Eventually, even samba would take its place as part of the MPB category, as MPB becomes a broad umbrella for "quality national music." 


\section{The Voice and National Identity}

As the only instrument capable of articulating words, the voice, for better or worse, has been one of primary instruments in the nationalistic agenda of any government regime. Besides the nationalist samba lyrics ordered by Brazil's Vargas regime, choral music became a platform for the raising of children's voices for the cause of national unity. Avelar and Dunn point out, "In the realm of mass culture, the state [Brazil] tolerated and even endorsed forms of sanitized popular music, but a program of choral music, with roots in European tradition, prevailed in the schools" $(2011,16)$.

In more subtle ways, the voice in MPB remains the carrier of brazilidade, creating a cultural stamp or "national brand" of singing through timbre, texture and voice technique. Though there are many vastly different ways of singing in Brazil, the bossa nova way of singing becomes a national identifier. Just as samba is not the only rhythm performed in Brazil, it nevertheless gets mapped as the national music and dance to this day. The process of musical nationalization occurs through transnational routes, as the country defines itself both in dialogue with outside musical practices, and by building and internal canon to shore up unity within. Perrone and Dunn note that in the last two decades of the twentieth century: "This new category [world music] allowed for the marketing of Brazilian popular music outside of jazz, its typical channel of international distribution since the success of bossa nova" (2002 (2001), 7). The special relationship between MPB and jazz will be discussed further in this chapter. 
Enriquez's article on the state-sponsored music scene in Recife, Brazil, makes use of Bakhtin's concept of voicing, as elaborated by Agha and Silverstein (Enriquez 2012, 535). Voicing in this sense can be described as a way of communicating and constructing one's identity by the choice of discourses and ways of speaking. It is a way of differentiating, or representing oneself socially, to align oneself with a particular group, in much the same way as described by Bourdieu ([1979] 2004). Enriquez extends the idea to music, as another semiotic mode of communication (2012), something Coakley's assessment does not take into account when placing emphasis on lyrics alone.

As mentioned in the introduction to this chapter, I understand music to play a major role in the construction of national identity, which intersects with classbased, gendered, and racialized identities. Avelar and Dunn insist that music is not merely reflective of political realities, but that music and political life are mutually constitutive $(2011,5,7,27)$. They support the view that music is playing an increasingly significant role in citizenship as it is experienced in Latin America $(2011,4)$

State and industrial-commercial powers have had a great deal at stake in the definition of strong national identity, from the independence movement of the late $18^{\text {th }}$ and early $19^{\text {th }}$ centuries. Populist dictators, in particular, have often tapped into the power of music to shore up support and create a sense of national unity. Latin Americanist Gilka Wara Céspedes outlines the involvement of state funding to support Bolivian traditional music festivals $(1993,55)$. Turino explains that appealing to middle-classed labour support became the strategy of governments to 
create centralized loyalty of an entire nation, which previously had been characterized by more regional economic allegiances $(2003,182)$. Turino points to several methods of state intervention in popular music, such as support of loyal artists, national anthems and festivals, that have contributed to the formation of a national canon of music in the contexts of Brazil, Mexico, Peru, Argentina, as well as Colombia and Zimbabwe (2003). By comparing the cases between these countries, Turino emphasizes the related effects of capitalism and nationalism. He states: "The suggestion here, then, is that capitalism and nationalism once again operate in consort and can have similar effects on regionalism, but for different reasonsprofit versus strengthening the state" (Turino 2003, 195).

Although vocal aspects of national musics remain an understudied field, most Latin American countries have come to be associated with particular dance music genres, through discourse, technology, government and industry support, as well as cultural and artistic production. Often regional or local to begin with, these genres are chosen as national symbols for political reasons, and are used to advance the cause of social and political elites by co-opting support from the masses.

Turino uses the examples of Brazil and Dominican Republic to highlight the common phenomenon of a regional style taking on national proportions.

Styles once strongly tied to given regional identities become indexically related to each other and to the "nation" by repeatedly juxtaposing them in performances in schools, festivals, and presentations by state-sponsored folkloric groups and through verbal nationalist discourse" (Turino 2003, 195).

Turino further explains, highlighting the notion of inscribing the body with national sentiment: 
By repeatedly juxtaposing pre-existing regional indices within the same contexts, the image (icon) of the "nation" emerges as the combination of these attractive sights and sounds: "this mosaic of regions and beautiful traditions is our country." Thus, an abstraction, "nation", is given flesh and blood, a perceivable form. (Turino 2003, 196)

I would argue that the voice, as the bodily instrument par excellence, is one of the main sites of embodiment of national identity in sound, together with the kinesthetic and visual of the dance, and the timbre of typical instruments, such as the guitar or percussion.

In his study at the turn of the new millennium, Frota questions what he calls the "semi-official" history of MPB a "crystallisation of half truths into whole truths" as enacted in media discourse, that privilege music from one region (the south-east - which includes Rio de Janeiro and São Paulo), over all others in what he calls a "continental country" $(2000,9)$. Frota further explains that in Brazil it is common to regard "good popular music" as containing "good lyrics and good music/melody." He argues that musical hits that circulated through Rio passed as "national" musical expressions, this fact being "naturalized" by local media, despite the enormous size of the country $(2000,17)$. I will discuss the idea of "good" or "quality" music further in Chapter Two. For now it is important to note the "crystallization" process to which Frota refers. Like Turino, he finds that through repetition, localized musics can become construed as national in scope, so long as the political and commercial will are in place, and the conditions of international tastes are favourable. Ethnomusicologist Suzel Ana Reily argues that the kind of music that is deemed national, or representative of a national identity, is determined by the dominant classes $(2000,7)$. On the other hand, Coakley observes that nationalism can almost 
always be seen from two viewpoints: that of the dominant group and that of a counter-group seeking to reshape its status $(2012,23)$. I believe this is a valid explanation for some of the shifts that have taken place within the canons of MPB, which I will discuss further below.

While Latin American state powers supported particular artists and musicdance genres to bolster national unity, they also made use of repressive measures against racialized minority groups long before the independence movements took hold. In the case of Brazil, the largest importer of African slaves in the world and the last country to ban slavery (in 1888), Avelar and Dunn demonstrate the control of the state on African musical practices (referred to as batuques):

On the one hand, there is evidence to suggest that some slave owners saw batuques as a convenient weekly ritual for mitigating tensions inherent in a slave economy... On the other hand, these gatherings also posed a threat to plantation owners and government officials, who feared large congregations of black people and frequently imposed measures to inhibit or prevent them. $(2011,8)$

Historian and critical race theorist George Reid Andrews explains that many strategies were used by Afro-Latin Americans throughout slave history to resist repression-for example negotiations with masters, speeding or slowing down of work rhythms, strike action, appeals to state authorities, forming family units, engaging in African-based cultural practices (2004). He argues that those strategies did not succeed in creating adequate conditions for the Afro-Latin American population. On the contrary, slaves were met with increased force, crackdowns, and regulation of African-based cultural practices. However, combined with the independence movements all over the region, these strategies improved life 
conditions and opportunities for Afro-Latin Americans to move up in social status. He points out that the legacy of past racism is still felt today, and that there remains much discrimination and racial prejudice (Andrews 2004, 10).

Critical race, gender and post-colonial studies theorist Cheryl Sterling discusses the post-abolition Brazilian policy of embranquecimento (whitening) of 1889-1911, which ceased to accept immigrants from Africa or Asia, while encouraging immigration from Caucasian people in order to lighten the colour of the Brazilian population $(2012,4)$. The term "whitening" has also been used to refer to the process of altering African-based cultural practices to appeal to broader markets, and particularly conform to Western aesthetics and practices (Aparicio 1998, Feldman 2012, Karppinen 2016). Chasteen clearly makes a parallel between the result of the "whitening" (or smoothing out) of the tango, with the contemporaneous policy of whitening of the Argentinian population (2012 (2000). Chasteen (2004) and historian Peter Fryer (2000) both trace the genealogy of samba as it stemmed from the more "transgressive" dances of the maxixe and lundu, which featured hip movements associated with African dancing, and a closed position associated with European dances such as the waltz and the polka. The combination of closed position and hip movements made these dances seem quite lascivious to many in the dominant classes. Chasteen attributes the choice of samba as the national rhythm partially to its perception as being more "wholesome" than its predecessors, due to the fact that it was danced in open position at the time $(2004,45)$ 
A key point of Andrews's work is that African-based cultural practices (rumba, son, samba and merengue, for instance) became the most popular, in spite of their being disdained by the elites initially. He writes: "This was most clearly the case with African-based music and dance, which were now held up as the most "authentic" expressions of national uniqueness" $(2004,166)$. Like Andrews, Fryer contends that African musical practices, far from being as peripheral as the social status of Afro-Brazilians would suggest, actually defined and shaped what is Brazilian music. He describes Afro-Brazilian music as one of resistance, through its many phases of development (2000). In his estimation, musical resistance was achieved by, for instance, slaves camouflaging African religious practices in syncretisms with Roman Catholicism; slaves transmitting clandestine messages through work songs; former slaves of diamond mines refusing to work for bosses who had banned vissungos (work songs); slaves engaging a "go-slow" work campaign, or pretending to be stupid; slaves attempting suicide or abortions; flight; blocos afro 5 boycotting centennial celebrations of abolition (2000). Clarence Bernard Henry also examines how Afro-Brazilian culture is appropriated as the mainstream Brazilian way, yet he reminds us that Afro-Brazilians still represent the lowest strata of Brazilian society to this day $(2008,10)$.

In her comparative multi-disciplinary study, Garramuño examines both tango and samba to reveal the processes by which these musical genres became national symbols in Argentina and Brazil respectively (2011). She does so through analysis of song lyrics, film, painting and literature. She describes how the interplay

${ }^{5}$ Blocos afros are parading groups from 1970s Salvador da Bahia who "consciously sought to re-Africanise their music" (Fryer 2000, 24). 
of "primitivism" and "exoticism" on the one hand, and nationalism and modernity on the other, converged in the 1920s and 30s to construct national musical genres. She explains the contrast between European primitivism of that period, which denigrated Latin American music to a lower level, to Latin American primitivism, which highlighted and exoticized so-called "primitive" aspects of the music, to differentiate it from European music, and thereby establishes it as national. In this way, Latin American primitivism can be seen as synonymous with criollo nationalism $(2011,18)$. In samba, this is accomplished by reclaiming African aspects, while in tango, its perception as "autochthonous" carries it to national status (Garramuño 2011, 44). She states: "Tango and samba became national symbols in the 1920s and 1930s precisely because they present the best example of this condensation of modernization and nationalization" $(2011,75)$.

Garramuño maintains that the processes of nationalization and modernization not only happened simultaneously, but were also mutually constitutive. She adds:

The conversion of tango and samba into symbols of a national identity is a product of the degree to which this process was tied in with the modernization of Argentine and Brazilian cultures. $(2011,14)$

Garramuño further highlights the paradox of nationalism versus cosmopolitanism that exists within tango and samba practices.

In both processes [nationalization of tango and samba] we can note that cosmopolitanism is not opposed to nationalism in the specific forms that this apparent contradiction acquired for Latin American cultures, but instead that they constitute two sides of the same coin. For the avant-garde, tango and samba are amphibious products representing both the local, national primitive and the sophisticated and modern quality 
of the European primitive concept, which is so important in a certain European avant-garde current that it will serve as the model, often implicit, for reassessing the value of the primitive in Latin America. $(2011,51)$

From these reflections, we can observe the tensions that exist between traits that are associated with either European or African cultures. While musics and dances mix as magnetically as the people who practice them, there is a tendency to continuously try to separate out elements in an attempt to vie for political status. For instance, the "popular" becomes associated with the physical body, lower classes, and Africaneity, while the "erudite" becomes associated with the mind, upper classes, and European origin. This odious, and perhaps oversimplified delineation highlights tensions that mirror the discourse of human survival instinct through power and difference.

As ethnomusicologist Jeff Packman observes in the case of Salvador, Brazil, discourse in Salvador associates "good music," with the upper class and European aesthetics, while "bad music" is associated with lower classes, and is African-derived (2011, 429). He describes European aesthetics as: "for example, harmonic complexity, elaborate arrangements, internal logic, and serious, introspective poetry" (428). He discusses axé (pronounced "a-shay") and pagode (pronounce "pagoji”) genres-two popular dance genres in Northern Brazil—which get conflated as Bahian music, pointing out that they are frequently criticized for not measuring up to European aesthetics (429). Packman points out that this goes against the understanding of Brazil as a country of mestiçagem, upon which the national identity is largely based (429). 
With the foregoing discussion, I have summarized some of the key ways in which music and movement practices are used to inscribe national identity on the bodies of citizens. Indeed, many of the scholars mentioned above assert that the musics that acquire national status in Latin America are often "whitened" versions of African-based genres, that is, their rhythms are simplified and movements are smoothed out, and reproduce aesthetics that belong to a European worldview, albeit one that exhibits a penchant for "exotic" African elements. One can surmise that this strategy is fairly effective in appeasing both sides of the socio-economic spectrum, allowing everyone the potential to identify at least partially with what is deemed to be national music. Lower classes try to acquire higher status by conforming to an aesthetic associated with upward mobility. And higher classes can congratulate themselves for being "inclusive." Those who do not identify with the mainstream, tend to seek ways of circumventing the national altogether. What is apparent is that the underclasses (mostly occupied by racialized "others") have historically sought ways of maintaining their musical practices in the face of considerable pressure from dominant groups (usually Euro-descendants) who outlawed them (at worst), or obscured and appropriated them (at best). What is at stake for the underclasses is cultural survival. What is at stake for the dominant classes is the retention of power through exclusionary practices (or "whitening"), camouflaged by the appearance of a unified nation.

MPB presents a case in point. In many ways, today's MPB could be seen as a catch-all category that attempts to nationalize various genres and distil them through a filter of European aesthetics. However, I do not think it is as simple as 
accusing the elite of reproducing a colonial gesture. The musicians I spoke to, who aim to make "música boa" (good music), and lament the lack of space for it, do so with a great deal of artistic and ethical integrity. Perhaps at issue is the label "música de qualidade" (music of quality) which is often juxtaposed with "música ruim" (rubbish music), and privileges intellectualized music over the bodily experience of dance music. The assumption that dance music is of lesser quality is certainly problematic. And I suspect that if music makers of all sorts were better compensated for their work, and did not have to contend with an industry that has professional and amateur musicians alike competing for crumbs, that there would be no need to pit musical genres against each other to prove which one provides the best product, or even more importantly, represents the country. The stamp of "music of quality" also presumes a certain distance from commercial forces, in order to preserve a notion of artistic authenticity. As we will see in the second chapter, all of these factors come to define MPB, and by extension, Brazilian national identity.

\section{Singers in a composer's domain}

What I have found to be missing from the debate on musical nationalism is a question of proportional participation and agency between men and women. I must ask, who is represented by national musics? Many scholars have problematized racialization and class struggles with regard to Latin American musics, pointing out that the kinds of music that are deemed national, or representative of a national identity, are most often determined by the dominant classes (Reily 2000, Moehn 2007). However, male hegemony of popular musics in Latin America seems to be an 
issue that remains underdeveloped. A few scholars have taken on the gender question directly in Latin American popular music context.

Transnational Latino/a popular culture theorist Maria Elena Cepeda examines the discourse in popular media regarding Latino music, focusing her attention on the Colombian community of Miami and the 1990s Latin music boom (2010). Ethnomusicologist Lise Waxer's book on the salsa scene in Cali, Colombia, shows how the pan-Latino identity intersects with the local. She explores how salsa's adoption in Cali intersects with issues of class, racial and ethnic identity, gender and age (2002). Waxer offers that the desire of "black" and "mulatto" Caleños to differentiate from Colombian national musics is perhaps partially due to the long-standing and systematic discrimination and racism that they have suffered in that country $(2002,24)$. She also discusses the phenomenon of gendered ensembles that exists mainly since the 1980s in the Cali salsa scene, stating: “...the rise of all-woman salsa bands among the second generation of Caleño salsa fans, along with other developments in the local scene, points to a particularly clear instance of the difference that gender and generation, along with race and class, can make" $(2002,27)$. Latin American literary and cultural studies expert Frances Aparicio exposes evidence of long-standing discrimination against racialized peoples in Puerto Rico, and in particular against racialized women (1998). Her book Listening to Salsa is an indictment of European male patriarchal hegemony.

In the Brazilian context, Bruna Queiroz Prado is currently pursuing her doctoral research on the tensions between vocalists and instrumentalists in MPB, at the University of Campinas, near São Paulo. Her conference papers show a growing 
interest in the impact of female intérpretes in MPB. In her case studies of Elis Regina and Maria Bethânia, she highlights some of the same observations I have made regarding the creative input of vocalists and the not-so-accidental silo of women in this role. She states:

Bethânia, simbolicamente, se apropria do espaço que foi dado às mulheres no meio musical, aquele ligado às artes corporais, vocais e de interpretação, e o utiliza para transgredir a submissão feminina a um ambiente profissional que se formou como um lugar de homens. $(2016,6)$

Bethânia, symbolically, appropriates the space that was given to women in the musical medium, that which is linked to bodily arts, vocal and interpretive, and uses it to transgress feminine submission in a professional environment that was formed as a man's place $(2016,6)$.

Sociologist Patricia Hill Collins leads the way in intersectional theory and appropriate consideration of how race and gender are completely intertwined with age and ability and other axes of identity (2016). My dissertation did not seek to define and explore the terms of "race," "class" and "gender." However these are issues that certainly come to bear in my exploration of the voice in MPB, and are threads that run through every chapter of my study. Reframing the discussion around the intérpretes of MPB reflects a particular set of concerns. It foregrounds the notion of gender in the study of a national music such as MPB, and has the potential to transform our understanding of the narrative surrounding national character. What have vocalists done that has been dismissed in the narrative surrounding MPB? Instituting a shift in how nationalism has been addressed in popular music allows us to refocus on the important participation of intérpretes, thus creating a space to include women in the national narrative. 
I have chosen to examine the role of intérprete in MPB, as it is by far the most common entry point for women in this musical field that has grown into a music of national status. ${ }^{6} \mathrm{~A}$ focus of authorship that is mostly leveraged on composition, combined with systemic discouraging of women from participating in this activity, have effectively kept women at bay in the top positions in the canons of MPB.

Singing, on the other hand, seems to be the path of least resistance for women who want to be MPB music makers. (I explore this question in depth in Chapter Four.) Although it may seem as though vocalists perform as mere vehicles of delivery for the composer's intention, my position is that vocalists are actually partners in the musical creation process, a position shared by Prado.

Chico Buarque, um dos compositores de quem a cantora [Maria Bethânia] mais gravou canções, a caracteriza, por sua vez, como uma coautora de suas obras, interpretando as mudanças de notas e células rítmicas que ela insere nas canções, não como falta de rigor técnico e musical, mas como um refinado trabalho de apropriação da obra, que acaba por transformá-la (Prado 2016, 6).

Chico Buarque, one of the composers whose songs the singer [Maria Bethânia] recorded the most, characterizes her, in turn, as a co-author of his works, interpreting the pitch and rhythm alterations that she inserts in the songs, not as a lack of technical or musical rigour, but as the fine work of appropriation of the work, that ends up transforming it (Prado 2016, 6).

Buarque's openness to the role of the intérprete is particularly astute. At the same time, the above quote displays the exception that proves the rule. It highlights the fact that an intérprete requires legitimation by a male composer. And the presumption of a "lack of technical or musical rigour" is part of what keeps women

\footnotetext{
${ }^{6}$ A further study on non-vocal activities of women in MPB would make a fascinating follow-up to the current study.
} 
from occupying the top echelons of the MPB canons. (Canons will be discussed in detail in Chapter Two.)

Through their interpretation, through their sound, female musicians are in fact an essential part of MPB creation, even though their names are often secondary to their male counterparts in the literature on MPB. Indeed, as was evident in the presentation given by Álvaro Faleiros in Ottawa, entitled “New Brazilian Popular Music" (2013), there is a conspicuous absence of female composers in MPB discourse. Intérpretes occupy a paradoxical position, as the central figures as lead singers, but secondary in status in this composer-centred practice, if they are considered musicians at all. As we will explore further in subsequent chapters, women have often occupied side roles, such as "muse" or "hostess," while their contributions as musicians have been underplayed. Such is the case for singer, dancer and group leader of the Rosa Branca (White Rose) carnival troupe, Tia Ciata, at the turn of the $20^{\text {th }}$ century. Chasteen shares her history as an important force in the development of future samba schools of Rio, which now all feature dancing baianas ${ }^{7}(2004,38)$, but no one has yet to discuss what she may have contributed to the sound of samba, even though we do know that singing was a major component of typical ensembles of the type she initiated. Dona Canô, the famous mother of Caetano Veloso and Maria Bethânia is mostly heralded for her community leadership and "open door policy" (G1 Globo 2012), but her musicianship through

\footnotetext{
${ }^{7}$ Dancing baianas are women from Bahia, traditionally performing in parades as shepherdesses in the Epiphany story, though they also adopted secular themes under Tia Ciata's leadership (Chasteen 2004, 39). They typically dress in white, dance, sing and play percussion instruments.
} 
singing, albeit recorded on film ${ }^{8}$, is not mentioned or recorded in histories of Brazilian music, such as Severiano's (2013). Nara Leão, considered to be the "muse of bossa nova" (Severiano 2013, 345), is known for hosting formative gatherings by bossanovistas ${ }^{9}$, but is usually referred to as a "cantora" or "intérprete," obscuring the fact that she often accompanied herself on guitar. All too often, the very deep contribution of vocalists to the national narrative through song, gets dismissed in favour of the men who compose and play instruments. Spheres such as hosting, raising musical children, teaching and singing, resonate as a typical list of roles that have been traditionally accepted as feminine domains. I will return to this question in the fourth chapter.

The story of how, and why, Machado founded her music school offers a case in point. She demonstrates at once the significance of the voice in MPB, while simultaneously enacting the circumscribed gendered roles by participating in spheres that are traditional thought of as feminine, that is, singing and pedagogy.

É a música brasileira que sempre foi a motivação do meu trabalho. Sou uma cantora de música brasileira, de canção brasileira. E eu entendi também, nos anos que estava trabalhando, pesquisando, já com a abertura da escola, que passa a ter o nome Canto do Brasil a partir de 1997. Em 1994 se chamava Timbre. Mais tarde eu comecei uma pesquisa sobre a tradição da música vocal popular. E como os cantores vinham aprendendo a cantar, cantando, ouvindo os intérpretes que eram referências. Aprendi a cantar ouvindo a gravação, às vezes imitando. Então fui reconhecendo nisso que a gente tinha uma tradição importantíssima, super consolidada, uma tradição "cancional" e vocal, que é uma referência para o mundo todo. Talvez principalmente através da bossa nova, mas não só a bossa nova. Com esse estudo, com essa investigação, eu foi cada vez mais me especializando, no assunto da canção brasileira, e foi

\footnotetext{
${ }^{8}$ Dona Canô can be heard in the following video clip: https://www.youtube.com/watch?v=ekwf21RsDk0.

${ }^{9}$ The term 'bossanovista' is often used to denote bossa nova musicians.
} 
estruturando uma metodologia de ensino na qual no processo de aprendizado você percorre a história da canção brasileira no século $X X$, e vai compreendendo através da escuta, como essa voz possui referenciais. Como esses referenciais se transformam ou se mantém iguais a través do tempo? Que caminhos são esses que essa voz vai percorrendo? E por isso mesmo constituem um patrimônio imaterial de valor imensurável. Não dá pra medir isso. E como isso é uma bandeira política também, porque isso é uma coisa que tem ideologia, obviamente. Então a escola não podia ter outro nome. Aí nasceu "Canto do Brasil". (laughs) (Machado, personal interview, June 23, 2015)

It is Brazilian music that has always been the motivation for my work. I am a singer of Brazilian music, of Brazilian song. And I understood, as well, in the years that I was working, researching, and already through the opening of the school, which came to be named Canto do Brasil in 1997. In 1994, it was called Timbre. Later I started research on the tradition of popular vocal music. And how singers came to learn to sing by singing, listening to the intérpretes that were references. I learned to sing by listening to recordings, sometimes imitating them. So I was recognizing in this that we had an extremely important, super-consolidated tradition, a song and vocal tradition, that is a reference for the entire world. Perhaps mainly through bossa nova, but not only bossa nova. With this study, with this investigation, I was specializing more and more on the subject of Brazilian song, and was structuring a methodology of teaching whereby in the learning process you run through the history of Brazilian song in the twentieth century, and will understand through listening, how this voice possesses references. How those references are transformed or maintained the same through time. What routes is this voice taking? And this is why they even constitute an immaterial heritage of immeasurable value. It cannot be measured! And how this is a political banner also, because this is an idealogical thing as well, obviously. So the school could not have any other name. So "Canto do Brasil" was born. (laughs) (Machado, personal interview, June 23, 2015)

Machado's contribution to the development of MPB in the São Paulo region is evident in the number of people who have been touched through her entrepreneurship and teaching. When I ask Machado if she composes music as well, she tells me that she does compose, but that she considers herself mainly an intérprete. She humourously calls herself a "compositora bissexta" (Leap-year 
composer), minimizing this aspect of her creative work (Personal interview, June 23, 2015).

As highlighted by Machado, bossa nova is the single most important turning point in the history of Brazilian singing. I will therefore proceed to give a brief outline of the history of MPB in terms of bossa nova, its pre-history, and the development of MPB since bossa nova. This is by no means an encyclopedic account of all the singers and styles that have occurred in the last century ${ }^{10}$. Although our focus here is on the intérpretes, it is appropriate to discuss MPB in general terms, to understand the singers' place within it.

\section{"MPB" as an umbrella label}

In 1964, Brazil experienced a military coup d'état that ostensibly aimed "to free the country of corruption and Communism and to restore democracy" (Fausto and Fausto [1999] 2014,273). This began a period of twenty years of military dictatorship, characterized by heavy industrialization, coupled with poor living conditions. Many people, who were considered subversive, were tortured and killed (Fausto and Fausto [1999] 2014). Artists from the second wave of bossa nova, such as Chico Buarque, began to write songs of social commentary in the 1960s.

Christopher Dunn describes the musical result as "well-crafted compositions that encompassed both romantic lyricism and social critique" $(2001,56)$. Also during this period, a group of musicians from Bahia moved south to pursue musical careers

\footnotetext{
${ }^{10}$ For a compendium of female Brazilian singers' biographies from the last century up to the present, please see http://www.cantorasdobrasil.com.br.
} 
in Rio and São Paulo. This group, referred to as "o grupo baiano" (the Bahian group) included Maria Bethânia, her brother Caetano Veloso, Gilberto Gil, Gal Costa and Tom Zé (Dunn 2001, 56). It was Maria Bethânia who had secured the opportunity to work in Rio, having been invited to Rio by Nara Leão to participate in a TV show called Opinião. Bethânia was obliged to travel accompanied by her younger brother, Caetano Veloso, in order to preserve propriety. She was also criticized for her dynamic range and low voice; for her thin body covered by unrevealing clothing; for her serious facial expression (Prado 2016). Prado notes that Bethânia transgressed traditional female stereotypes in many ways, including leaving home for music, focusing on her own career, and creating independence, even from her brother $(2016,3)$.

O grupo baiano was largely responsible for the rise of the Tropicália movement, which unlike bossa nova, was interested in creating Brazilian music from roots genres from the north and centre of Brazil. One of their goals was to protect the identity of Brazilian music from foreign influence, particularly rock and roll. Together, the bossanovistas and tropicalistas ${ }^{11}$ created the first songs to be identified as MPB, which were protesting against the military dictatorship (Tatit 2004, 54; Dunn 2001, 56). Soon after, the term was used to refer to music from the 1960s televised song contests, which specifically aimed at creating a body of music that was uniquely Brazilian (Ulhôa 1995). It is from this cohort that several of the enduring representatives of MPB, the ineluctables, emerged: Bethânia, Buarque, Costa, Gil, Milton Nascimento, Elis Regina, Veloso, Tom Zé. It is to be noted that from

${ }^{11}$ Tropicalistas refers to musicians from the Tropicália movement. 
this list of luminaries, the men are all primarily known as composers or cantautores, while the women are primarily known as intérpretes, or cantoras. Also apparent in this list, is the fact that, as Perrone and Dunn point out, "A most significant aspect of the definition of new musical styles in this period is the interaction of black and white musicians" ([2001] 2002, 8).

Since the 1960s, the term MPB has gradually come to constitute an umbrella term, under which many genres are grouped. The TV festival MPB was in part a reaction to bossa nova, which had been criticized for being influenced by foreign music, namely jazz (Perrone and Dunn ([2001] 2002). Bossa nova, which was popular for a very short period from the end of the 1950s to the mid-1960s was overtaken in popularity by the protest song and TV festival MPB generation. Bossa nova nevertheless retained its position as one of the most important genres within MPB, as it was bossa nova that provided the singing style that would be employed by many who would identify it as the "Brazilian way" of singing. This singing style is said to have been introduced by João Gilberto, who personified the malandro ${ }^{12}$ character and shocked his audience with his audacity to sing softly (Castro [1990] 2000). I find it suspect that while Nara Leão was hosting parties, singing, and playing guitar to accompany herself at roughly the same time, in Rio, communing with the same crowd of musicians, João Gilberto is forever cited as the inventor of the bossa nova sound. And though they had the same skill set - singing, guitar playing - she is known as "the muse" of bossa nova (Castro [1990] 2000, 179; Severiano 2013, 345). Gilberto is "the inventor." She is the object. He is the subject.

${ }^{12}$ The malandro is a sharply dressed trickster who epitomizes a questionable work ethic and survives by his wits. 
Though far from universal, the singing technique that defined the bossa nova period, is what is taught in university settings until this day. It was more than a fad. On the contrary, it is still very frequently employed, and described, by Brazilian singers as a naturalized, almost essentialized way of singing that is often equated with Brazilianness. Even though there are plenty of examples of singers who do not fit this mould, and whose sonic imprint is nevertheless engraved in the canons of the most celebrated Brazilian performers, many singers of all racialized categories treat bossa nova singing as the ideal type of Brazilian singing. Elis Regina, consistently cited as one of the top three singers in Brazilian history, stands out as a singer who, although paired up with many of the most venerated bossa nova era composers, did not always embrace the João Gilberto lightness of tone that came to be known as typical of Brazilian singing. This forces us to acknowledge one of the many paradoxes of Brazilian society, that even though a particular style occupies the largest portion of the public imaginary as the norm, there are many exceptions that disrupt expectations.

Also, it must be noted that a contrasting singing style, that comes through the genealogy of Afro-Brazilian singers such as Clementina de Jesus. It is the style of singing that would have been practiced by Tia Ciata, mentioned above. It is associated with candomblé spiritual practice and work songs of the Northeast, and has renewed vigour in samba singing. The sound can be described as having a high degree of pressure in the throat, making use of mostly chest—and at times nasalresonance, characteristic of call and response singing. The volume achieved is generally associated with untrained voices, and is contrasted to the "sophistication" 
of bossa nova singing. Nevertheless, because of its roots in mostly Afro-Brazilian Northeast, this sound carries with it a great deal of legitimacy, and the weight of authenticity. An example can be found in Joana Mariz's description of up-andcoming singer Juçara Marçal.

Juçara met Kiko Dinucci. He is a big researcher of African traditions in Brazil. They met, and Juçara also has this interest, as she's black. And in candomblé traditions and stuff. And they started working together, and created this incredible group, in my opinion, Metá Metá. They compose things mainly inspired in the Afro-Brazilian traditions. And this exploded. She is doing very well. I don't know if she is in Brazil now but she goes abroad and does 30 concerts outside Brazil, with this group. At first it was MPB. Then they launched Metal Metal, which is a record where they use distorted guitars. It's kind of a Fela Kuti sound. It has some saxophones and African percussion, and Brazilian lyrics. It's what we call a mistureba. It's like everything in the pan. And Juçara is doing very well with her career. She won the critics' prize for best album of the year. And now she has launched after, I don't know, 30 years of career, she finally launched a CD on her own: Juçara Marçal Encarnado. And she won all the prizes of the critics because she is proposing this: a mixture of folk traditions with Afro traditions which is a little bit different because she is thinking about candomblé. And singing in a way that maybe resembles work songs, more than bossa nova. She is more shouty than João Gilberto. (Personal interview, June 11, 2017) ${ }^{13}$

It is perhaps very telling of Brazil's social hierarchy that the singing style associated with bossa nova, with its trappings of sophistication, which was led by young Eurodescendant middle-class musicians in Rio de Janeiro, has come to symbolize Brazil the world over. That said, there is more and more space for various types of singing under the MPB category, that now intermingle with the bossa nova style in artists such as Fabiana Cozza. I will explore this paradox further in the fourth chapter. Other genres, such as Northeastern forró and baião, and choro carioca can now also

${ }^{13}$ This interview was mostly conducted in English. 
be employed under the umbrella of MPB even though they are considered traditional genres. They are genres that are ascribed authenticity by virtue of their geographical origin, their characteristic scales and rhythms, as well as their less commercialized nature. Chapter Two will address all of these aspects of MBP canons in depth.

\section{Foreign influence: Jazz and MPB}

The transnational aspect of MPB is most obvious when alluding to the influence of United States musics, particularly jazz. As Vianna notes, moments of collective ambivalence in relation to foreign influence have occurred frequently throughout the history of MPB ([1995] 1999, 93). Usually, this takes the form of a debate between traditionalists who claim a new style of music threatens the fabric of Brazilian culture, and youth or modernists, who want to renew that very national identity. Both sides make use of nationalist arguments to support their case (Vianna [1995] 1999, 95).

Carmen Miranda was the darling of Getúlio Vargas in the 1930s, at a period characterized by what Vianna describes as the "triumph of the 'mestiço paradigm"” ([1995] 1999, 94). This period produced a major swell in Brazilian identity, propelled, as mentioned above, by the work of Gilberto Freyre, who claimed that Brazilian culture was defined by "racial mixture," rather than hindered by it. Miranda, who was Portuguese born, but grew up in modest conditions in Rio, made no excuse for her adoption of Afro-Brazilian garb in her performances (Davis 2009). 
She was instrumental in the crossover of the baiana style ${ }^{14}$ into mainstream samba music. Davis, for his part, describes Miranda as not a crossover artist, but rather a "bridge between the national and the popular" $(2012,182)$. In other words, her sartorial choices, which belonged to a racialized underclass, mixed with her privileged position as a Caucasian woman in the inner circles of dictatorial government, helped to legitimize the Afro-Brazilian element in the national music in the eyes of the middle to upper classes (Davis 2009, 125).

Miranda's presence in the US brought her particular brand of the samba sound to Hollywood films, which were one of the most powerful vehicles for jazz music at that time. Upon her return to Brazil, from a massively successful stint in the US, she was accused of selling out to "Americanization", even though she may be the most internationally recognized figure associated with Brazil, “- except perhaps João Gilberto and Antônio Carlos Jobim, the creators of bossa nova, whose 'Brazilianness' was also called into question..." (Vianna [1995] 1999, 93). As Vianna points out: foreign influence was seen as treason ([1995] 1999, 84), and I would venture to say that in some circles, it still is today.

Musicologist Martha de Ulhôa also points to this ambivalence toward foreign influence, stating: "The name ["MPB"] appeared in the 1960s in discussions centering on the controversy over the 'internationalization' of Brazilian popular music and its 'selling out' to jazz (bossa nova) and rock (jovem guarda, or 'young guard')..." $(1995,160)$. Televised festival MPB was in part a reaction to the perceived foreign influence of jazz in bossa nova in the late 1950s, prompting a

\footnotetext{
${ }^{14}$ Please see footnote 7 , page 38.
} 
desire to create a uniquely Brazilian style of music. Television broadcasting had made its appearance in Brazil in 1950, but only became accessible to a large portion of the population by the early 1960s. According to Severiano, television programming took its lead from the successes of radio, which were presenting "os grandes cantores e cantoras da época" (the great male and female singers of the era) $(2008,347)$. On the political side, the capital of Brazil was moved from Rio to Brasília in 1960, by the Kubitchek government. This was a highlight of a period of great economic growth and international trade for the country, increasing the profile of Brazil on the world stage. There was a mood of ambivalence between fear of United States political and economic interference on the one hand, and a great mistrust of communism and unions on the other. The battle between anticommunists and anti-capitalists was such that nationalism was flourishing on all sides, culminating with the military coup of 1964 . Several industries were nationalized in the early 1960s (Fausto and Fausto [1999] 2014). This is the climate within which the televised song contests were founded, in the hopes of nationalizing a canon of Brazilian popular music.

Some pre-bossa nova singers, like Nora Ney, Johnny Alf and Dick Farney were imitating the Frank Sinatra/Bing Crosby line of crooning (Castro [1990] 2000). The intimate style of singing that was typical of the crooners, was a direct result of the invention of microphone technology, which meant a singer no longer had to project the voice in the same manner as before, to fill a hall. Nara Leão, Sílvia Telles, Alaíde Costa, João Gilberto, and others brought this new up-close style of singing to its limit, practicing an extremely soft vocal production that was at first perceived by the 
public as poor quality and even in some cases considered "out of tune." The very song "Desafinado" ("Out of tune"), by Tom Jobim, was a response to the negative outcry from some quarters about the bossa nova (or "new way") of singing.

Despite early criticisms, the bossa nova way of singing is one of the most important reasons that the genre as a whole came to be accepted as a hip urban variant of samba that was intended for listening, rather than dancing. Understated vocals are one of the hallmarks of bossa nova, along with harmonies and an abundance of chromaticism borrowed from American cool jazz. It was borrowed in much the same way as a linguistic borrowing, which rather than being perceived as an imitation, becomes part and parcel of the host language.

In a nutshell, the well-off white urban youth of the 1950s rebelled in their way and created this genre, bossa nova, that they preferred. Bossa nova was hip because of its international influence, and ironically, was more often than not written on themes of love, even though bossanovistas were known to mock as "oldfashioned" the sorry love themes of its predecessor, samba-canção. Bossa nova itself quickly passed into "old-fashionedness" when the next generation, more racially mixed but still gendered (Nascimento, Gil, Veloso, Buarque, to name a few) created a sound that was stubbornly acoustic. Snubbing electronic instrumentation as a resistance to "selling out" to the cultural imperialism of Anglo-American music, they used politically savvy lyrics to send their message under the censorship radar of a nascent dictatorship.

All the while vocalists like Gal Costa, Elis Regina and Maria Bethânia were at the service of the above-mentioned composers, interpreting their songs and 
negotiating their way through gendered pronouns and representation. However, as Prado demonstrates by way of a case study on Elis Regina, through performance, the vocalist was able to communicate on levels that were outside of the capacity of the written form. By allowing, for instance, irony or humour to enter into her interpretations, she was able to critique the dictatorship in ways that were impossible to censor. Prado claims that in this way, Regina was able to subvert gender norms and use music to "colocar sua voz no mundo" (to place her voice in the world) (September 2016, 14).

Subsequent genres, such as Tropicália and Jovem Guarda (Young Guard), made use of electronic instruments, which, to many, was tantamount to selling out to foreign musical influence (Dunn 2001, 65). As Dunn outlines, these two genres, and their audiences, were at odds over questions of quality and commercialism. Jovem guarda can be described as apolitical Brazilian rock music of the 1960s, that "lacked the musical and poetic sophistication of MPB" (Dunn 2001, 61). Lead by the "king of iê-iê-iê15," Roberto Carlos, Jovem Guarda had a particularly masculine focus. Dunn states: "Themes of male bravado, sexual liberation, fashionable clothes, fancy cars, and wild parties are most typical of Jovem Guarda songs" $(2001,60)$. While MPB was bolstered by the television festivals, which produced hit songs that would become part of the national canons, Jovem Guarda attracted mass audiences in a way that eluded the MPB circuit. It was as though the Jovem Guarda community were a faction, splitting away from the MPB circles.

\footnotetext{
${ }^{15}$ Iê-iê-iê was a nickname given to Jovem Guarda music, referring to the style of music reminiscent of the Beatles' "She loves you, yeah, yeah, yeah."
} 
Caetano Veloso and Gilberto Gil may have been the primary agents for the fact that MPB today has come to signify Brazilian popular music in such broad terms. They had all the credibility that was afforded to them by their origins in Bahia, their gender, their middle-class status and education, their combined embodiment of the mestiço paradigm, and by their status as songwriters. Their participation in bossa nova music, followed by their success in televised MPB festivals in the late 1960s, made them the ideal candidates to anoint the more massively popular Jovem Guarda as a component of the eventual definition of MPB as a catch-all label representing Brazilian popular musics on an national and international scale. The pair's openness to electric instruments would appeal to mass youth audiences, but their credibility with the "old guard" would be well established. The result of this bridging between genres means that nowadays, if one turns on MPB radio, one can expect to hear anything, from samba and bossa nova to what sounds for all the world like American pop music sung in Portuguese. Regina Machado explains: “O termo MPB hoje, ele é aplicado genericamente. Quer dizer, tudo que se canta em português virou MPB: Música popular brasileira. Nem sempre foi assim" (Today the term MPB is applied generically. That means, everything that is sung in Portuguese has turned into MPB: Música popular brasileira. It wasn't always this way) (Personal interview, June 23, 2015).

Commercial interest of radio stations notwithstanding, there remains a great deal of tension between MPB as "music of quality" and what is generically referred to as MPB. The label has the purpose of constructing national identity and is in constant tension with what is perceived as foreign, even when the foreign is the 
element that seems to keep MPB from disappearing into a museum category. Foreign influence seems simultaneously to signal the modern, and appeal to the rebellious nature of youth. As new genres have come into being in the history of MPB, the old ones remain and continue to be practiced. So MPB also serves as a unifying label across generations, again fortifying the formation of a lasting canon of Brazilian music. MPB seems to be a bit like a religious practice that falls out of favour with passing generations, yet remains as a pillar of the society, holding on to its architecture, its institutional structure and its die-hard supporters and practitioners.

The historical trajectory of jazz has many parallels with that of MPB, in that it stands as a broad category of subgenres that have come to be defined by, and as, canons. The table below, while far from a comprehensive picture of the histories of these musics, compares some of the key features of jazz and MPB. Their juxtaposition can provide a sampling of how they both behave as canons, rather than genres. 
Table 1: Comparison of Jazz and MPB

\begin{tabular}{|l|l|}
\hline Jazz & MPB \\
\hline $\begin{array}{l}\text { Swing era (Golden age: 30s-40s): dance } \\
\text { music, popular style }\end{array}$ & $\begin{array}{l}\text { Samba era (Golden age: 30s-40s): dance } \\
\text { music, popular style (Carnival) }\end{array}$ \\
\hline $\begin{array}{l}\text { Bebop and Cool jazz (late1940s- 60s): } \\
\text { intellectualized, becomes unpop vis-à-vis } \\
\text { rock and roll }\end{array}$ & $\begin{array}{l}\text { Bossa nova (Late 1950s-60s): } \\
\text { intellectualized, moves into unpop vis-à- } \\
\text { vis Jovem Guarda, Tropicália }\end{array}$ \\
\hline $\begin{array}{l}\text { Vocal and instrumental variants and } \\
\text { performances }\end{array}$ & $\begin{array}{l}\text { Vocal and instrumental variants and } \\
\text { performances16 }\end{array}$ \\
\hline United States national music & Brazilian national music \\
\hline $\begin{array}{l}\text { Combination of European harmonies and } \\
\text { African rhythms }\end{array}$ & $\begin{array}{l}\text { Combination of European harmonies and } \\
\text { African rhythms }\end{array}$ \\
\hline Female vocal divas & Female vocal divas \\
\hline Male crooners & Male crooners \\
\hline $\begin{array}{l}\text { Professionalization: institutionalized } \\
\text { through university programs }\end{array}$ & $\begin{array}{l}\text { Professionalization: institutionalized } \\
\text { through university programs }\end{array}$ \\
\hline Improvisation & $\begin{array}{l}\text { No extensive improvisation traditionally, } \\
\text { but interpretation is important } \\
\text { component, and improvisation is fair } \\
\text { game }\end{array}$ \\
\hline
\end{tabular}

Jazz is often cited by Brazilian musicians as a source of inspiration and even as an important component of their musical education. Although I will explore their stories in more detail in subsequent chapters, Rosa Passos, Evandro Gracelli, Irajá Menezes, Lívia Nestrovski, Beth Amin, all mentioned jazz in their discourse about MPB. Jazz provides a model for an intellectualized middle-class music, and occupies the same strata as MPB in terms of its middle position between classical and pop, yet Brazilian jazz singers are still differentiated from MPB singers in large part. Even though jazz and MPB coexist as "quality musics," being presented at the same venues for instance. The main difference is the perception of national belonging.

\footnotetext{
${ }^{16}$ The proportion of vocal to instrumental music in jazz and MPB varies, but they both exist in each category.
} 
As we can observe in the table above, the most significant difference between the trajectories of jazz and MPB is that jazz is largely based upon extended improvisation, while MPB, is not, at least not traditionally (Horta, personal interviews, May 12, 2016; Padovani, personal interview, June 29, 2015). In her description of the popular music program at UniCamp in the early 1990s, Lu Horta distinguishes between jazz and MPB: "Aí tinha uma coisa muito forte com o jazz e com improvisação. E eu vinha muito mais na MPB, na música brasileira assim" (There was a very strong thing with jazz and with improvisation. And I was much more in MPB, in Brazilian music as such)(Horta, personal interview, May 12, 2016). For her part, Izábel Padovani is an example of how intérpretes have incorporated the principal of jazz improvisation while still considering herself an MPB singer.

Porque a música americana, por exemplo, o jazz vai ter uma escola de improvisação vocal, onde você até aprende aquelas pronuncias. $E$ na música brasileira, a gente não tem improvisação vocal. A música popular brasileira, ela é a canção brasileira, mas não tem improvisação vocal. A tradição não é essa. E quando você pensa nisso, na essa improvisação vocal brasileira, no meu caso é bastante brasileiro. Não se parece nada com a música americana. Eu tenho vocábulo todo construído em cima da língua portuguesa. (Padovani, personal interview, June 29, 2015)

Because American music, for example, jazz will have a school of vocal improvisation, where you even learn those [scat syllables]. And in Brazilian music, we don't have vocal improvisation. Brazilian popular music is Brazilian song, but does not have vocal improvisation. That is not the tradition. And when you think of it, of this Brazilian vocal improvisation, in my case it is quite Brazilian. It does not resemble American music in the least. I have a vocabulary that is completely constructed from the Portuguese language. (Padovani, personal interview, June 29, 2015)

I would argue that Brazilian singing has an improvisational affinity to jazz in that from the outset, the Brazilian vocal tradition requires the singer to 
interpret songs, altering the phrasing, dynamics and rhythms to suit her reading of the lyric. And although the practice is contested, many MPB singers even alter melody notes for interpretive purposes. So while it may not have been conceived as full-on solo improvisation using vocables (scat syllables) over the length of a chorus, for instance, as in jazz, Brazilian vocalists have engaged regularly in a degree of ad-lib vocal gestures. In other words, interpretation implies a certain amount of freedom and improvisational approach to the singing, making interpreters co-composers of sorts.

The line between a Brazilian jazz artist and an MPB singer who engages in improvisation is very thin. A case in point is Luciana Souza, who is a self-described jazz artist. She was born and raised in São Paulo, but has lived and worked in the United States since the 1990s. Before her departure to the United States, Souza was a teacher in the prestigious and seminal MPB program at UniCamp in the early 1990s. (I will discuss this program more in Chapter Three on MPB pedagogy.) Much of her repertoire consists of MPB songs. In addition, she has brought an MPB singing style to the jazz she sings in English, showing that the relationship between jazz and MPB is not uni-directional. One of her former students, Regina Machado, who now heads the very same program at UniCamp (besides running her private music school, Canto do Brasil), had the following to share about Souza.

Luciana Souza é uma grande cantora, quem vive nos Estados Unidos há muitos e muitos anos. Ela mora em Nova Iorque. Quando eu ingressei na UniCamp, em 1992, a Luciana dava aula lá. Eu fui aluna dela durante um semestre. Depois ela voltou para os Estados Unidos. Então, eu acho que a Luciana é uma grande cantora. É excelente. Tem uma voz linda. Canta muito bem. E já está mais identificada e 
mais ambientada com o jazz, do que com a música brasileira. E quando ela canta música brasileira, ela faz uma escolha de, de certa maneira, hibridizar essa música. Então ela junta essa música brasileira com o jazz. Ela é uma jazzista, Luciana Souza. (Machado, personal interview, June 23, 2015)

Luciana Souza is a great singer, who has lived in the United States for many, many years now. She lives in New York. When I entered UniCamp, in 1992, Luciana was giving lessons there. I was her student during one semester. Then she returned to the United States. So I think that Luciana is a great singer. She's excellent. She has a beautiful voice. She sings very well. And she is still identified, and more accustomed, to jazz than Brazilian music. And when she sings Brazilian music, she makes a choice, in a certain way, of hybridizing it with jazz. She is a jazzista, Luciana Souza. (Machado, personal interview, June 23, 2015)

I cannot help but wonder if Souza's choice to live in the United States may be the

biggest factor in her being excluded from the MPB label. Horta, also a former student of Souza's at UniCamp, confirmed the jazz bent of Souza's teaching when I asked her to tell me more about the contents of the course.

A gente trabalhava muito com o repertório de jazz. Então a gente pegava os standards. Ela [Souza] falava sobre o uso do microfone. Ela falava sobre a curva melódica, e na coisas bem técnicas assim. Uma coisa que eu agradeço muito a Luciana, em que ela trabalhou muito com a gente, quando você ia estudar uma música, você estudava harmonia inteira. Então a gente cantava os acordes inteiros, todos aqueles trabalhos de improvisação, entendeu. Ela deu muita ferramenta para a gente nesse sentido. Depois até eu fui ver isso de novo na aula de percepção do Ricardo Breim, a maneira como eles trabalhavam percepção também vinha por ali. Mas dentro do repertório mais vinculado a um repertório de jazz, apesar de entrar bossa nova, de entrar música brasileira, mas a partir dessa abordagem, dentro desse contexto. (Horta, personal interview, May $12,2016)$

We worked a lot with the jazz repertoire. So we took up the standards. She [Souza] talked about the use of the microphone. She talked about the melodic curve, about quite technical things as such. One thing for which I am very grateful to Luciana, on which she worked a lot with us, when you went to study a song, you studied the entire harmony. So we sang the whole chords, all those 
improvisation exercises, you understand. She gave us many tools in this sense. After that I even saw that again in Ricardo Breim's ear training classes, ${ }^{17}$ the way they worked on perception also came from there. But within the repertoire that was more linked to a jazz repertoire, in spite of entering bossa nova, of entering Brazilian music, but from that approach, within that context. (Horta, personal interview, May 12, 2016)

Souza herself does not use the term "MPB" in her biographical notes, choosing to emphasize her propensity for musical mixture. Her biography reads: “Luciana's work as a performer transcends traditional boundaries around musical styles, offering solid roots in jazz, sophisticated lineage in world music, and an enlightened approach to new music" (Luciana Souza n.d.). One could argue that Souza's espousal of mixture, as a musical value, is one of the most Brazilian aspects of her work. Whether or not she is entitled to a place in the history of Brazilian music, she certainly embodies the close relationship between jazz and MPB. Not accidentally, her biography's allusion to sophistication can be read as a direct reference to her background in MPB. It should be noted that the term MPB is not broadly known outside of Brazil, and that her word choice here may be a savvy way to avoid confusion inherent in attempting to define MPB and all its subgenres.

Two of MPB's top intérpretes, Rosa Passos and Leny Andrade, whom I met while in São Paulo, are both strongly inspired by jazz. Both make use of extensive improvisation in their singing, including scat singing, but are considered first and

${ }^{17}$ Ricardo Breim is a well-respected pianist, teacher of composition and harmony, and the owner-founder of a private music school by the name of Espaço Musical (Musical Space), in São Paulo, which will be discussed further in Chapter Three on MPB pedagogy. 
foremost MPB singers, or as they would more commonly refer to themselves, Brazilian singers.

I have wondered why Souza is not admitted as a Brazilian singer. There is the obvious fact that she lives, and has lived in the United States for many years, which may be considered "treason," along the lines experienced by Carmen Miranda. On the other hand, João Gilberto, the uncontested father of bossa nova singing, also traveled and worked in the United States, but his reputation survived any doubt about his “Brazilianness," as expressed by Vianna ([1995] 1999). Gilberto's wife, singer Astrud Gilberto, who remained very popular in the United States and is considered one of the representative voices of bossa nova throughout North America, also tends to be dismissed as an insignificant figure in MPB, at least within the São Paulo MPB community. That said, the difference between a Rosa Passos or a Leny Andrade, and a Luciana Souza, is said to be the linguistic angle of national identity. Regina Machado offers this explanation:

Eu acho que há bastante semelhança com a Leny Andrade. Embora eu sinto que Leny Andrade fez um esforço, e conseguiu, no sentido de criar uma marca, no scat singing, que é um tipo de silabação que aproxima muito da sonoridade da língua brasileira, da língua portuguesa. Eu não vejo isso na Luciana. Também acho que ela não tem essa preocupação. É uma outra época, uma outra geração. Com a Rosa Passos, eu vejo ela mais por um viés através da bossa nova, da bossa nova referenciada em João Gilberto. Eu acho que a Rosa Passos, ela tenta traçar esse diálogo, tendo como referência a estética sonora firmada por João Gilberto. E aí estabelece um diálogo com o universo do jazz, o que é uma abordagem talvez mais intimista, mais próxima do cool jazz. ... Então acho que a música brasileira, o tempo todo, dialoga com a música internacional, com a música latino-americana, com a música norte-americana, predominantemente, acho até mais do que com a música europeia. Mas esses diálogos, esses pontos de tangência, esse encontro sempre acontecem. Em várias épocas é possível a gente ver isso. Nos anos 40, por exemplo, você vê cantores como Dick Farney, que é um cantor brasileiro. É uma relação muito 
próxima com a sonoridade que se estabelecia através das canções de Cole Porter, de Gershwin, e de cantores como Frank Sinatra, Bing Crosby, né. Então esse diálogo, ele existe o tempo todo. (Personal interview, June 23, 2015)

I think that there is a good deal of similarity with Leny Andrade. Although I feel that Leny Andrade makes an effort, and succeeds, in the sense of making a mark, in scat singing, that is a type of syllabification that much approximates the sonority of the Brazilian language, of the Portuguese language. I don't see that in Luciana. I also think she doesn't have that preoccupation. It is another era, another generation. With Rosa Passos, I see in her more of a bias toward bossa nova, referenced in João Gilberto. I think that Rosa Passos, she tries to trace that dialogue, having as a reference the sonic aesthetic signed by João Gilberto. And there she establishes a dialogue with the universe of jazz, which is maybe a more intimate approach, closer to cool jazz. ${ }^{18}$... So I think that Brazilian music, always dialogues with international music, with Latin-American music, with North-American music predominantly, I think even more than with European music. But those dialogues, those tangential points, those conjunctures always happen. In several eras it is possible for us to see that. In the 1940s, for example, you see singers like Dick Farney, who is a Brazilian singer. It is a very close relation with the sonority that was established through the music of Cole Porter, of Gershwin, and of singers like Frank Sinatra, Bing Crosby. So that dialogue, it exists all the time. (Personal interview, June 23, 2015)

One of the newest incarnations of this dialogue with American popular music, is the current trend among young Brazilian voice students to sing in a Broadway musical style, or an American pop style à la Beyoncé, much to the chagrin of several MPB voice teachers with whom I spoke (Amin, Mariz, VocalSP, personal and group interviews, June 2015). The existence of the TV show "The Voice Brasil" is a big attraction for young Brazilian singers. Mariz offers this explanation:

The American Idol aesthetic came to Brazil. But before American Idol's franchising we had the entering of the Broadway musicals

${ }^{18}$ Cool jazz is a 1950s subcategory of American jazz, lead by trumpeter Miles Davis, characterized by "modal, impressionistic, hard bop, and quasi-free styles" (Gioia 1997, 225). 
franchising. So, Les Misérables, Phantom of the Opera, and stuff. And these are jobs. New singers want to live. They want to survive out of music. So they go and sing musicals, because the big money is that. People pay a lot. They have I don't know how many sessions a week, that pay. So, my students want to know musicals, how to sing in musical theater. And MPB, not so much. (Personal interview, June 11, 2015)

Mariz goes on to explain that to work in MPB, singers can expect to work mainly in bars, and may hope to take home about 100 reais in a night (less than $\$ 50 \mathrm{CDN}$ ). Their prospects of making a living are far too scant to make this attractive, so they gravitate to musical theatre. ${ }^{19}$

It is important to note that genres such as jazz, rock and hip hop are often treated in Latin American countries less as borrowings from the United States than as global genres applied by, and for, particular taste categories and classes. While hip hop serves throughout Latin America as music of the downtrodden and disenfranchised (Dennis 2008, Magaldi 2008), rock is seen as the music of rebellious youth (Cepeda 2010, Avant-Mier 2011), and jazz holds the position of sophistication in popular music, a middle ground between classical and popular musics. So the association between jazz and MPB is largely based on these communities of taste, class and education as well as other similarities outlined above.

\section{Samba, National Identity and Mestiçagem (Mixture)}

Samba holds a very particular and paradoxical relationship with the MPB category. In some ways it is antithetical to MPB, or more particularly to bossa nova. It is music

\footnotetext{
${ }^{19}$ This opens up musical workforce issues, which is a topic worthy of its own study, and lies outside of the scope of this dissertation.
} 
from the favelas. It is dance music. It is generally sung full-throated, in a manner associated with Afro-Brazilians. And while it is the rhythmic basis of many genres, including bossa nova, it often gets compartmentalized as "black music." Established as Brazil's official national music since the 1930s (Vianna [1995] 1999), samba is treated as a traditional music, a roots genre with its own set of sub-genres, such as samba-enredo (carnival samba), samba da rua (street samba), samba-canção (samba ballad). MPB, on the other hand has an air of modernity, sophistication and cosmopolitanism that are associated with urban music of the "white" middle class.

It took me quite some time to realize that even samba can paradoxically also be subsumed under the current and broadest MPB umbrella category. It came to my attention that Fabiana Cozza, an active samba singer based in São Paulo, is considered an MPB singer as well. Unlike the traditional samba singer, though, she has university-level music education and literacy, and performs in soft-seat concert venues, which are formal settings that fetch higher ticket prices. Most samba singers perform in dance clubs, singing at very high volumes, in outdoor neighbourhood street venues, or carnival parades in groups of hundreds. Whether a samba singer is considered MPB seems to depend greatly on their level of education, where they perform, and importantly, with whom they associate. In other words, MPB implies a higher class status than traditional samba would.

As samba is the representative rhythm of the nation, it could be argued that samba artists have no need for the MPB label. However, the relationship between MPB and samba is symbiotic and is founded on the politics of labeling. As MPB is known as "music of quality," music of the middle- to upper class, being known as an 
MPB-samba singer legitimates, and even elevates the status of the artist in question. Conversely, samba lends its weight as the national rhythm to MPB. It legitimates MPB as a populist category, and authenticates it as Brazilian through Africaneity ${ }^{20}$. It effectively creates a model for the altruistic dream of miscegenation, which albeit exposed as a myth (Henry 2008), nonetheless remains a very strong component of how Brazilians define themselves. Perrone and Dunn posit: "Samba has been implicated historically in making hegemonic the ideology (or myth) of racial democracy in both official and popular discourses. The effect of that myth is to deflect race-conscious dissent" ([2001], 2002 26). This may very well be the case. However, I would argue that the artists in question, far from deflecting, are actually enacting and modeling an ideal. As Sterling puts it:

Rather than bowing out of the narrative of democracia racial, AfroBrazilians, I suggest, aim to create the dream of the pluricultural society that truly reflects the ideals envisioned through the lens of racial democracy, where their social and political currency are considered of equal value $(1995,207)$.

I would add that many non-Afro-Brazilian artists are accompanying that dream with a great deal of honesty and integrity, despite all evidence of institutional and systemic discrimination in all areas of Brazilian life. The MPB community in São Paulo, I have found, is wise to government mismanagement and corruption, and is very open to discussing their ideals of social and environmental justice. If anything, the artistic community and its audiences are a saving grace of leadership within a culture plagued systemic racism (Santhiago 2011, Burdick 2013).

\footnotetext{
${ }^{20}$ I use Africaneity in the manner defined by Darién Davis: “... to refer to a group of cultural practices, ideas, or sensitivities understood by Brazilians as pertaining to AfroBrazilian culture..." (2009, ix)
} 
Three vocalists who came of age in the 1990s-Ceumar, Fabiana Cozza and Mônica Salmaso-performed together in a concert at the SESC ${ }^{21}$ Vila Mariana, on April 10, 2016. The concert was produced by up-and-coming vocalist Lívia Nestrovski, and her guitarist-partner Fred Fereira, who will be discussed further in subsequent chapters. The description of the concert in question includes the following:

Gravado no SESC Vila Mariana, em abril de 2016, o show visita lugares do interior do Brasil nas canções de Ceumar, passando pelo Brasil brejeiro de Mônica Salmaso e pelo Brasil negro de Fabiana Cozza. (SESC Brasil 2017)

Recorded at the SESC Vila Mariana, in April of 2016, the show visits locations in the interior of Brazil in the songs of Ceumar, passing through the Brejo area of Brazil [in the Northeastern state of Maranhão] of Mônica Salmaso and through the black Brazil of Fabiana Cozza. (SESC Brasil 2017)

There is a clear attempt here at giving a broad, albeit selective, representation of the country's musical heritage within the context of MPB. Some of the most important values of MPB, namely nationalism, and the sound of the voice itself are evidenced in the very title of the show: "Vozes que interpretam o Brasil" (Voices That Interpret Brazil) (SESC Brasil 2017). It is worth noting that these voices are feminine, that the three vocalists chosen collectively embody mestiçagem, and that they are presenting what would be considered "music of quality," while invoking the nation as a whole.

The mestiçagem in question is not a random blending of cultures, but rather a specific celebration of Africaneity within a hegemonic Western environment. The

${ }^{21}$ SESC (Serviço Social do Comércio [Social Service of Commerce]) is a national network of community centres, funded by commercial entities. SESC provides libraries, sports, concert halls and art galleries, among other activities. For more information on the impact of the SESC, please see Gough 2015, and Galletta 2016. 
rhythms of all genres belonging to MPB, not only the samba, are rooted in African traditions. As mentioned in Chapter One, Fryer posits that African musical practices form the basis upon which all Brazilian musics were founded..$^{22}$ Indigenous traditions seldom, if ever, make themselves felt in what is called MPB. As Álvaro Faleiros ${ }^{23}$ pointed out to me, the fact that his collection of indigenous musical recordings is kept in his study, rather than in his living room with the rest of his CDs, is an indication of the fact that he thinks of these as something "other than" mainstream (Personal interview, September 13, 2013). Mainstream urban society in Brazil generally effaces indigeneity in favour of European-based "culture" and African "roots;" the two main ingredients in the mestiçagem that still defines Brazilian identity in many ways. By intentionally contrasting "roots" and "culture" here, I am turning the spotlight on associations drawn between those two founding peoples and the class to which they pertain. These expressions harken back to by now antiquated perceptions of high and low art, which run parallel to the fear of African musics as bodily, while elevating European musics as intellectual (Andrews 2004, Dixon and Burdick 2012). It seems that samba is admitted to the MPB category only in cases where it satisfies the canons of MPB, as I will describe in detail in the next chapter.

\footnotetext{
${ }^{22}$ Please see Chapter One, page 30.

${ }^{23}$ Álvaro Faleiros is a professor of French letters at the University of São Paulo. He directed the Panamérica canção project, is a singer-songwriter and guitar player, and was one of my gracious hosts while I was in São Paulo.
} 


\section{Conclusion}

The foregoing discussion of MPB has focused on nationalism as a primary value, bringing forth the entanglements of gendering, racialization and class distinctions. Throughout this chapter, I have taken the reader on a journey through some of the paradoxes that make Brazilian popular song so compelling to study. How does a music get mapped on a national level when it is not the most popular of genres? How does a composer-centred practice place so much emphasis on interpretive performance? How do women get placed high on the pedestal of the lead voice, while still being constrained by the narrowness of that pedestal? How do samba, bossa nova, Tropicália, MPB, baião, choro, forró, and more, come to belong to the same musical category? How does a national music simultaneously embrace and reject foreign elements? How does a popular music betray an underlying Eurocentric worldview, while celebrating Africaneity? It is my hope that the following chapters will help to elucidate these questions, if in no other way than to struggle with them. 


\section{Chapter Two: MPB and Its Canons}

As discussed in the first chapter, the different definitions of the term "MPB" sometimes lead to confusion about its meaning. Ethnomusicologist Frederick Moehn defines MPB as "a broad category of music encompassing various styles and often (although not exclusively) associated with a middle-class public" $(2007,185)$. Reily points out that in $20^{\text {th }}$ century Brazil, the canon of national popular music has been defined by "samba, bossa nova and MPB" (2000, 7). Moehn's definition uses the term as an umbrella category while not referring to canonicity per se. Reily's usage of the term places MPB alongside other genres that form the canon of Brazilian popular music. While in this instance Reily does not explicitly define MPB, one may take it to mean the post-bossa nova movement from the 1960s. However, my research leads me to conclude that the term "MPB" as it is used today is more effectively viewed through the lens of canonicity, as opposed to genre. For clarity, I will refer to the genre of music that emerged from televised festival MPB circuit of that era as "TV MPB."

In this chapter, I first present a discussion on canonicity and the ways in which it can be applied to MPB. The Oxford dictionary defines a canon in four ways, two of which are particularly germane to this study. One type of canon, which is most often applied by music scholars, is a body of work belonging to one or more authors, for instance the Bach canon, or the canon of German classical composers. Oxford also defines a canon, as "a general law, rule, principle or criterion by which something is judged." Based on these two definitions, I lay out six canons that have emerged from the current investigation, which I will explore at length individually. 
The first of these canons is the one that conforms to the first definition mentioned above, namely, the body of work represented by specific artists who are deemed the most important figures in MPB. In order to distinguish this canon from the others, I will capitalize "MPB Canon," as it is from this from this body of work that all the other canons of MPB emerge.

The second canon is MPB as national music, as opposed to regional. This section will build upon the discussion begun in Chapter One on musical nationalism, with a specific look at the national aspect of MPB. The third canon-MPB as "quasipopular" music-examines the ways in which popularity, or lack thereof, is deployed in the construction of MPB. The fourth canon is MPB as quality music. This section explores the meaning and implications of quality, particularly with respect to class differences. The fifth canon-MPB as vocal music—calls attention to the ubiquity of the voice in Brazilian popular music, and its importance in the performance of national music, and by extension to national identity. The sixth canon-MPB as composer-centred music—brings forth the notion that the composer and "his" work are the primary authority that operates within MPB. Themes of gendering, racialization and class distinctions run through all of the canons.

The menu of canons I propose should not be seen as an exhaustive list, as further study may reveal another layer of canons, or sub-canons. Nevertheless, framing MPB in terms of these multiple canons offers the possibility to highlight the political nature of its construction, the many contradictions and implications of their application, and the very practical results of their hold on the public imaginary. In 
other words, what and who gets "admitted" as to the MPB category depends greatly on their ability to conform to those canons. Before we embark on an exploration of each canon in turn, a few words about the idea of canonicity itself.

\section{Canonicity}

In Distinction, Pierre Bourdieu explains how people construct themselves in part by associating with a desirable social group through taste in particular cultural products, such as movies and music ([1979] 2004). We align ourselves with communities of similar tastes, and thereby become or remain part of that group. Although not necessarily conscious, these taste decisions reinforce the status of the given social sphere by lending credence to it (Gracyk 2007; Frith 1996; Reily 2000). Conversely, one can distinguish oneself by differentiating from an undesirable crowd. Distance from the distasteful creates an air of distinction and sophistication. Canons are a powerful mechanism through which one can create distinction (Reily 2000, Talbot 2000, Jones 2008, Karppinen 2016).

In her seminal work Gender and the Musical Canon (1993), Marcia Citron unpacks the canonizing ideology surrounding the repertoire of Western European classical music. She explains that canons have a tendency to give a false impression of works as being timeless and fixed. They nevertheless set the standard upon which all other works are judged. She makes the important observation that the development of a canon depends on the existence of a fixed record of some sort, for example a written musical score, or an audio-visual recording. She points out that the concept of a canon of Western classical music was historically applied, in the 
discipline of musicology, to a body of repeated works that emerged in the $19^{\text {th }}$ century $(1993,17)$. Musicologist Michael Talbot shows the history of this very development, explaining that it was highly motivated by the fact that there was an increase in self-employed professional musicians, who engaged in independent commercial activities such as selling their compositions to publishers, taking private commissions, and giving music lessons and public performances. Talbot also reports that there was a simultaneous increase in the use of music as a recreational activity in itself, moving into a concert sphere where patrons would pay admission to hear the music for its own sake. In this context, audiences had an interest in knowing who had composed the music. Previously, music would have served a more functional purpose within church services, fairground gatherings and dining halls, for instance, where the focus was on the performers, not the composers (2000). This history serves to remind us that Western European Classical Tradition (WECT) ${ }^{24}$ was not always a composer-centred practice. Musicologist Richard Middleton points out that popular songs are subject to the same kinds of canonisation and treatment as reified objects as WECT pieces (2000). The Brazilian propensity to adopt a Eurocentric view of "high" and "low" musics is actually stemming from this $19^{\text {th }}$ century aesthetic. ${ }^{25}$ I will return to this point under the sixth canon-MPB as a composercentred practice.

One of the most important forces of canons is their ability to channel the values of a given group through taste. Citron proposes that: "canons simultaneously

${ }^{24}$ Western European Classical Tradition (WECT) is a term that was coined by musicologist Leo Treitler (cited in Middleton 2000, 59).

${ }^{25}$ This propensity is undoubtedly shared in other parts of the world, particularly in North America. 
reflect, instigate, and perpetuate value systems" $(1993,19)$. She further explains: "Canons embody the value systems of a dominant cultural group that is creating or perpetuating the repertoire..." $(1993,20)$. Citron's understanding of cultural value can be applied to our interpretation of MPB. In this regard, the most tenacious thread of motivation for the canon is Brazilian identity; defining it, preserving it, propelling a sense of national pride and belonging. But whose interests are really being served by the canon building process? Reily posits that the very genres associated with $\mathrm{MPB}^{26}$ align the canon with middle and upper class tastes, and in particular, those of Rio de Janeiro $(2000,7)$. I will expand on this topic in our discussion of the second canon of MPB, or MPB as quasi-popular music.

Citron's writing itself is an example of how deeply embedded canons become, in that even authors who see them for what they are -i.e. socially constructed norms of quality-use discourse that continues to reify the canons, possibly inadvertently. She states: “Anthologies have stressed Western art music and generally ignored other idioms, such as folk music, popular music and world music" $(1993,26)$. Although elsewhere she acknowledges the problematic nature of the term "Western art music," she still uses this label as though it were a fixed entity. To suggest that WECT musics have cornered the market on artfulness is offensive to many musicians around the world. She is right that the dominant mainstream of Western societies tends to view "Western art music" as the default repertoire, but this point of view falls into the trap. It is in itself, the dominant viewpoint. During my field research in Brazil, several consultants were quite confused when I referred to

${ }^{26}$ Reily lists samba, bossa nova and MPB. 
"world music" as though it were a genre. As far as they were concerned-and they were right—this expression only made sense if one sees the centre as the dominant Global North. What we call world music in Canada would include Brazilian popular music. However, to disrupt this centre-periphery perspective, as far as many Brazilian musicians are concerned, MPB is much bigger than that. It is "the Canon." And just as Vianna shows us that the "discovery of samba" is a myth ([1995] 1999), so is any notion of a unified, homogeneous Música Popular Brasileira. MPB is not, in fact, a musical style or genre, it is a set of criteria for admission to representing the Brazilian people, to itself and to the world.

Rock theorist Carys Wyn Jones outlines the advantages and disadvantages of canons, stating: "A primary function of canons is their ability to bring order to chaos, to essentially tell a story of our cultural history and present it in its most aweinspiring light." She further explains: "We cannot possibly absorb all the writing and music, not to mention art and dance, ever created, and the canon presents, in effect, a collocation of 'greatest works' to experience before you die" $(2008,7)$. Jones acknowledges the contradictory nature of canons, as they present a mythologized "truth" about a body of work, a truth that is in constant flux with the passing of time and new generations. She states: "As a collection of exemplary works, canons draw attention to the possibilities of a medium. They also implant the desire to struggle under the weight of the past to achieve comparable greatness" $(2008,7)$. Similarly Citron provides the following example in the WECT domain: "While an essay like 'Brahms the progressive' is a defensive strategy against charges of radicalism, it is also Schoenberg's way of forging a personal link to the pantheon of acknowledged 
greats" (Citron 1993, 28). Jones's pithy description of canons answers many questions in the case of MPB. The MPB canons are taught to younger generations as a means of preserving Brazilian culture from extinction, as Regina Machado articulated, because it has "immeasurable value". ${ }^{27}$ I have observed this in MPB as well. Any artist who would like to make a name for themselves (a telling expression in itself), must establish a relationship to the Canon. They must try, as much as possible to fit in, because the association with a body of work that already has acquired credibility is advantageous to one's career. It raises the status of the up and coming artist and their music. Furthermore, they must do so in such a way as to differentiate themselves from all of the artists who preceded them. Citron poses and important question:

What does the public "get" out of the canon?... Perhaps most importantly, the public seems to look to canons for setting standards of taste. If the work is in the canon, assumes a layperson, it must be good and something I should be familiar with. Furthermore, I should "appreciate," if not necessarily like, it and similar works. ... "canonically correct" knowledge confers a kind of moral imprimatur on its possessor. Somehow one is a better person with that erudition." (1993, 31)

I would surmise that what the Brazilian public "gets" out of the canons of MPB, is mainly a sense of national identity, which is tied to a need for belonging, both in the nation, and by extension a need for that nation to belong in the world, particularly taking its place in a world where it is often perceived and portrayed ambivalently as a "developed third world" country. Jones also offers other pedagogical advantages to the use of canons, which I will discuss in Chapter Three.

${ }^{27}$ Please see Chapter One, page 39-40. 
There are, of course, issues associated with canon formation, which, if exposed, can be somewhat mitigated. Hegemony, for instance, is a key element of canonicity. Citron affirms: "as the assumed repertoire Western art music does not have to identify itself as such" (Citron 1993, 26). Similarly, feminist musicologist Anne Karppinen argues:

Canons never speak of the conditions that shape them: instead of laying bare the cultural and societal forces that are at play in their formation, canons present works and artists by the virtues of their "genius", their "masterworks", their prowess and power. This is not to say, however, that canons are inherently evil.... Without canons, we would be faced with a mass of cultural products through which all of us would have to find our way alone; hence for teachers and researches, for instance, canons are a necessary tool (Karppinen 2016, 135).

While it may be tempting to brand the MPB canons (or any canons) as elitist, the deep complexity of their function cannot be underestimated or dismissed, as Citron, Jones and Karppinen's research attests. That said, and as Karppinen articulates so well: "Artistic merit does not always guarantee a position on the top shelf: it might not even be possible to scale the ladder. Class, age, gender, sexuality and ethnicity might prevent an artist even getting onto the first rung" $(2016,135)$. I would add that, paradoxically, these factors may even provide a gateway into the canons, turning exoticisms into authenticity, through acts of re-appropriation.

Acknowledging canons as both a body of work and as norms in their own right highlights their function as value judgments, and emphasizes their mutability and malleability. Discussing canons in this way can temper their hegemonic power, forcing us to reckon with the diversity of musics that exist in real life. And it forces us to take notice of artists and musics that may have been overlooked for political 
reasons. Citron writes: "A paradox emerges from the relationship between new music and canons" $(1993,23)$. If we examine the Canon in light of its canons, as norms themselves, then this issue goes away. New compositions can enter into relationship with the mould created by the historical Canon.

The question then becomes: who are the gatekeepers of the canons? In Citron's words: "who decides what is acceptable and what is unacceptable in canons-or more colloquially, what is in and what is out?" $(1993,19)$. Reily indicates that writers of music histories have a significant power to elaborate canons. She point to influential works, such as modernist writer, and intellectual, Mario de Andrade’s 1928 publication, “Ensaio sobre a música brasileira” (Essay on Brazilian Music)(cited in Reily, 2000, 3). Jones stresses the role of anthologies and educational institutions as primary "canonical curators" or "canonizers." She specifies: "However, schools are not the only institutional settings for canons: libraries, theatres, museums, publishing and printing houses, editorial boards and prize-awarding bodies all use canons to invoke high ideals and bring order to a field" $(2008,10)$. In addition to these, sociologist Alan Stanbridge indicates mass media, institutions of cultural policy, recording industries, the public $(2000,135)$. To this growing list of canonical curators, I would add producers, critics, venue owners, and there are surely others. All of these agents have different stakes and interests, and they can become competing forces in the contested field of canon formation. 


\section{Canon Number 1: The MPB Canon}

As the scholars mentioned above demonstrate, canons are usually defined by a specific repertoire, it is most commonly referred to in relation to the composers' names, which stand for that repertoire. As their names become synonymous with their music, so do they become anchored as "The Canon." Canonical figures are not all equal in weight. Their anchoring depends on repetition and breadth of consensus. Furthermore, Jones notes the notion of the "test of time," which canonical works are said to withstand. The "test of time" is a filter that separates high quality from that which is "disposable" (2008). She refers to the term "omnisignificance," coined by literary critic Frank Kermode, which applies to works that appeal to successive generations, as they renew themselves and their place in the Canon. This requires works to be recorded, in some form, to preserve them in collective cultural memory, "... enticing artists with the possibility of immortality" (Jones 2008, 10).

When speaking about the canon of Brazilian popular music, certain figures are indisputable. As in the canon of Western classical music, in which there is little to no argument of the inclusion of Bach, Brahms and Beethoven, certain Brazilian artists meet the test of public acceptance of their inclusion without question. The list reads something like: Maria Bethânia, Chico Buarque, Dorival Caymmi, Gal Costa, Gilberto Gil, João Gilberto, Tom Jobim, Milton Nascimento, Vinicius de Moraes, Elis Regina, Caetano Veloso. Looking back into the early part of the $20^{\text {th }}$ century, we add Cartola, Pixinguinha, and Noel Rosa. As time goes on, others get added to the list, like Ivan Lins, Victor Martins, João Bosco, Djavan. As we can see, the list is made up 
mostly of men, who are considered composers first of all, and a few female singers. The men usually play an instrument and accompany themselves, and they all sing (or sang) their own songs. Their names are at the summit of MPB. To be associated with one or more of them, is to be admitted to the canon. As Joana Mariz explained, even a pop star like Daniela Mercury, who performs axé music, which is not normally part of the MPB canon, can be considered MPB, so long as she is performing in the company of someone like Chico Buarque. And she need not change anything about the way she sings. Her sound is the same in the company of Buarque, but she can be considered MPB, which is the equivalent of rising in status in the hierarchy of Brazilian musics. The Canon of MPB is actually bolstered by the many popular artists—and the sheer number of genres they represent-clamouring to be associated with it.

Much of the MPB Canon was consolidated during the 1960s, as practiced by a group of musicians who participated in, among other genres, bossa nova and TV MPB (Dunn 2001, Tatit 2004). Since then, MPB has come to encompass genres of music, and bodies of repertoire, that existed long before the term MPB was in use. The Canon grows even though new genres fall in and out of favour. Joana Mariz illustrates this in her story of how the artist Lenine came to be part of the MPB Canon.

It's more and more difficult to distinguish MPB from other things. Some years ago I would say, for instance, when Lenine launched his $\mathrm{CD}, O$ dia em que faremos contato (The day when we will make contact), it was a big break for everyone because his previous CD was guitar and percussion. When he launched $O$ dia em que faremos contato he had electronics, he had sampling. And we were like: “okay, he wants to be pop. He doesn't want to be MPB anymore. We love him, but he's pop now." Then the next CD was even [more like 
pop], you know? And we said: "Okay he wants to be pop." And the next CD we said: "MPB is evolving." It's funny. Because it happened with so many people that we now see that as MPB. And that's it. At that point it was a conflict. Now it's not, anymore. (Personal interview, June 11, 2015)

Understanding MPB as a set of canons clarifies the "genre confusion" that is described by Mariz, as a canon can encompass many genres. As subsequent generations put their own stamp on the music, giving rise to new genre classifications, there still remains a collective impulse to define the music under a national banner. In so doing, a common, if imagined, thread runs between the early sambistas and "music of quality" of today, whether it be perceived as rock-oriented, jazz-oriented, samba-oriented, or any other genre orientation. Multiple musical scenes co-exist, and the boundaries of the MPB Canon are highly subjective. What matters is that to gain admission to the Canon, a song, an artist, must be deemed to conform to its component canons.

\section{Canon Number 2: MPB as national music}

The "B" in MPB, should speak for itself, but it is bound up in a complex configuration of factors both musical and extra-musical. For one thing, the musical classification that carries the Brazilian nationality by its very name does not represent most Brazilians, as we will see in the section on MPB as "quasi-popular music." It nevertheless reflects a desire to create a sense of national identity through music. Ethnomusicologist Philip Bohlman attests to the emotional charge of national music. He states: "At the end of the first decade of the twenty-first century, there still is no music that is as often celebrated and maligned as that which represents 
the cultural identities to which we ascribe the label nationalist" (2012, 34, emphasis in original). In the case of Brazil, Vianna explains:

It all comes down to a struggle between contrasting ways of organizing, conceptualizing, or interacting emotionally with our national culture ... on the one hand, the path of heterogeneity, where differences are clearly defined and encouraged; on the other the path of homogeneity, where the rule of indefinition blurs or contaminates heterogeneity without erasing it. ([1995] 1999, 109)

The very fact that so many genres can be considered MPB shows a certain unity in its disunity, which is both reflective and constitutive of Brazilian culture. As geographers John Connell and Chris Gibson remind us: "Nation-states have always been socially constructed" $(2003,117)$. They further explain: "Music, alongside national artistic traditions, common religions, ethnic identity and a range of visual symbols, ... is embedded in the creation of (and constant maintenance of) nationhood $(2003,118)$.

Brasilidade (Brazilianness), I noted during my first field research trip to São Paulo in 2012, is a great preoccupation, and a subject matter that comes up in conversation every single day, several times a day. It struck me, because I asked myself: how many times a day I, or anyone in my entourage, utter the word "Canada" in conversation? The answer was, not that often. But in Brazil, it seemed every time I was speaking with anyone, they would make a point of telling me "Ah, it's like that in Brazil," or “Oh, that's Brazil!” or "This is typical Brazilian," or some similar reply that indicated that brasilidade was the explanation for everything from chaotic traffic patterns to the use of literary language in popular song. On my second trip to São Paulo, I mentioned to Álvaro Faleiros that I would like to study the link between popular song and Brazilian identity. He replied that this was old news, that 
Brazilian identity was a question they had put to rest long ago, and that there was no reason to reopen it. So I persisted, and told him that most of my conversations there tended to veer toward identifying gestures, sounds, characteristics, idiosyncrasies, ways of being and behaving that were typically Brazilian. Faleiros appeared surprised, but immediately told me that I was right. And when I shared my impression that describing Brazilianness was a huge preoccupation there, he went even further, countering: "Pas une préoccupation. Une occupation!” (Not a preoccupation. An occupation!) (Personal interview, September 13, 2013). Along with soccer, music remains one of the most prized Brazilian cultural practices, one that carries a great sense of national pride both in and outside of the country. As legendary MPB singer Leny Andrade states: “Nossa música é a melhor do mundo! Pegamos o jazz, e o melhoramos!" (Our music is the best in the world! We took jazz, and we made it better!) (Personal interview, June 13, 2015).

Like Andrade, MPB icon Rosa Passos seeks to identify with this music on a national scale. One of the criteria for participating in her master class, for instance, was to sing what she called "traditional Brazilian music." She asked all participants to prepare one samba, one bossa nova, and one balada, from which she would choose two for us to perform for her. I was one of three participants from countries other than Brazil, and the only one from outside Latin America. The balada, as she defined it, is a ballad, in Portuguese, from the Brazilian repertoire. Passos made a point of explaining that samba-canção ${ }^{28}$ is the same thing as a balada. At least two

\footnotetext{
28 Samba-canção (samba-song), is romantic samba, with a slow rhythm that to many, carries an air of sentimentality (Castro 2000, 118). In the 1930s, when it emerged, sambacanção was seen more as a sophisticated type of samba, with beautiful poetic lyrics, that
} 
participants, composer-singer Beth Amin and I, had proposed to sing recentlycomposed songs. Amin proposed one of her own compositions, and I proposed one by my musical partner Evandro Gracelli, who is a local São Paulo composer, guitarist and singer. In both cases, our choices were rejected on the basis that they were not traditional songs. We were asked to perform "traditional" songs, in other words songs from the Canon. Passos was an exacting critic of the singers who performed at the three-evening-long master class, run by VocalSP. She reiterated several times during the course of these sessions that she was not there as a teacher, but rather as a guardian of the music (Public communication, June 22-24, 2015). She repeatedly made the point that we must all, as professional singers of this music, make it our business to sing with excellent intonation and diction. She emphasized that singers must listen to the band, playing in concert with them, rather than simply expecting the players to follow a singer who is not listening. She warned us not to let any musician treat us as "canários" (canaries). She advocated studying the music of other singers and instrumentalists as a matter of personal practice. Paradoxically, despite her insistence on the Brazilian tradition, she encouraged participants to study musicians from the North American jazz realm, stating:

O que mais me encanta, me ensina e me faz estudar sempre, ouvindo aquelas referências quem são as minhas divas do jazz, e os músicos do jazz. ... Não pra cantar jazz como americana, não. É pra tirar o senso do jazz, e transformar o jazz brasileiro, aprendendo como se faz o jazz. (Public communication, June 22, 2015)

What enchants me most, what teaches me and always makes me study, is listening to those references that are my jazz divas, and

is said to be the predecessor of bossa nova (Tinhorão, [1974, 1975, 1978, 1978, 1986, 1991] 2013, 182). 
jazz musicians. ... Not to sing jazz like an American, no. It is to get the sense of jazz, and to transform Brazilian jazz, learning how to do jazz. (Public communication, June 22, 2015)

All of Passos's advice appeared to hold the quality of the music to the highest of standards. She clearly wanted to convey a value of honouring Brazilian music, as she said: "Porque a música brasileira é ma-rã-vi-lho-sa!" (Because Brazilian music is marvel-lous!) (Public communication, June 22, 2015).

\section{National identity through the Portuguese language}

Fostering national identity is at the heart of the motivation to build and preserve MPB canons. One of the most important elements upon which this rests is the Portuguese language. As Benedict Anderson astutely pointed out in Imagined Communities, language is decisive in formation of national consciousness ([1983] 2006, 74). Regina Machado's assertion ${ }^{29}$ is echoed by Joana Mariz: "Some people say [MPB] is everything that's in Portuguese" (Personal interview, June 11, 2015). This statement reflects a very loose categorization of MPB, and a certain degree of sarcasm regarding the perceived poor state of current standards of quality in radio airplay choices. While it may be true that anything sung in Portuguese is fair game to play on an MPB radio station like NovaBrazil, for example, these programming decisions are based on financial or commercial considerations, more than musical ones, and do not reflect the sense of "responsibility to the music" that was conveyed to me by many musicians. Nestrovski offers the following insight:

${ }^{29}$ Please see Machado, quoted in Chapter One, page 51. 
Eu acho que a gente tem que também ter espaço pra todo tipo de música. Música que a gente mesmo acha ruim, faz parte dessa democracia, dessa diversidade cultural. Mas os meios mediáticos são regidos por interesse económico. E esses meios são regidos por gente que não entende nada de cultura. (Personal interview, July 15, 2015)

I think that people also need to have space for all types of music, Even music that people find rotten is part of this democracy, of this cultural diversity. But the media are governed by economic interest. And those media are governed by people who don't understand anything about culture. (Personal interview, July 15, 2015)

Not everything sung in Portuguese passes the test of being admitted to the MPB category in, for instance, a university level training program like the one at Santa Marcelina. Generally, the musicians I spoke to and spent time with agreed that MPB must be sung in Portuguese, but that is only the starting point. It is usually subjected to other musical criteria. And as Mariz indicated, genres such as sertanejo ${ }^{30}$ or axé are sung in Portuguese, but are not generally considered MPB. That said, as Mariz points out, an artist such as Daniela Mercury, who has a huge following in the axé genre, can occasionally be considered an MPB artist, simply by virtue of a performance with an undisputed MPB artist such as Chico Buarque. ${ }^{31}$ Her association with Buarque grants her "temporary visitor status" in MPB, which is not insignificant, as it confers greater respect and musical credibility. This is testament to the power of perceiving the Canon of MPB as middle-class music.

Amongst my consultants, I encountered a high degree of disenchantment toward most of the commercially popular music in Brazil, which is indicative of the

\footnotetext{
${ }^{30}$ Sertanejo is a genre from the rural interior of Brazil that is typically sung by duplas (pairs) in harmony. It is the Brazilian equivalent of country and western music.

${ }^{31}$ Please see page 76 of this chapter.
} 
longstanding tension between MPB and the Jovem Guarda rock-pop stream. I will discuss this further in the section on MPB as quality music. For the moment, it is important to underline that the Portuguese language is often the first filter that is applied to distinguish MPB from other musics, whether regional or international, and one that is a strong indicator of brasilidade. As Connell and Gibson note, "the maintenance of 'local [i.e. national] cultures' in the face of increasingly AngloAmerican popular music distributed by major record corporations" has been a concern for many countries, particularly those whose primary language was not English $(2003,119)$. Beth Amin explains:

Os jovens, eles escutam música americana pop. No máximo folk. E desconhecem a música brasileira completamente. Não gostam de cantar em português. Quando cantam em português, cantam com sotaque [americano]. E com riffs de rhythm and blues, de música black. E têm muita dificuldade de cantar uma música [brasileira], porque a beleza que eu sinto da música brasileira cantada tem uma franqueza. É uma extensão da fala. Claro que você pode ter ornamentos e tal, com outra música. Mas tem uma coisa do dizer, do falar, que está sempre por traz daquilo que a gente faz. (Personal interview, June 15, 2015)

Young people are listening to American pop. At most, folk. They ignore Brazilian music altogether. They don't like to sing in Portuguese. When they sing in Portuguese, they sing with an [American] accent. And with riffs from rhythm and blues, and black music. And they have a lot of difficulty singing a [Brazilian] song, because the beauty that I feel in sung Brazilian music, is that it has a certain frankness. It's an extension of speech. Clearly, you can have a ornamentation and such from other music. But there is something about speech, about the spoken word, that is always throughout what we do. (Personal interview, June 15, 2015)

Composer and music theorist, Luiz Tatit has built his entire career on the connections between Brazilian Portuguese and Brazilian melody. His premise is that melody stems from the language itself, with a strong focus on semiotics (Machado 
2011, 18). Tatit is part of the Vanguarda Paulista ${ }^{32}$ (Paulista Vanguard) from the 1980s, a group that gave rise to musical style that one might characterize as experimental narrative, almost theatrical, music, with very deep, gravelly men's voices and very high pitched ladies' voices. Tatit has garnered much respect for his work as a linguist and musician. And though his arguments are very often cited, his ideas are critiqued for being somewhat unidimensional, and perhaps short-shifting aspects other than speech, such as harmony, that stem from European musical concepts, not language (Mariz and Pantaleoni, Personal interview, June 11, 2015). As Marcos Pantaleoni, and classical pianist and pedagogue, offers, one could argue that the voice in MPB is sometimes used in imitation of Brazilian instruments and not the other way around. Such is the case, he says, in the song "Construção" by Chico Buarque, where the voice sounds as though it is imitating a tamborim ${ }^{33}$ (Personal interview, June 11, 2015). Having performed this song myself, I can agree that the words were written in such a way as to fit the melodic rhythm and not the other way around.

Nevertheless, there seems to be rather broad consensus among my interlocutors that the tones and rhythms of speech are at the heart of Brazilian singing. Beth Amin describes to me what she loves about old time sambista Cartola's singing this way:

...eu gosto muito de ouvir o Cartola cantando. Muito. E acho muito atemporal e muito moderno, porque tem muito da fala. Por mais que de alguns momentos, ele tem vibrato, né, é uma voz um pouco mais

\footnotetext{
${ }^{32}$ Paulista refers to inhabitants of the state of São Paulo.

${ }^{33}$ Not to be confused with a tambourine, the tamborim, is a small frame drum (15 to 18 $\mathrm{cm}$ in diameter), percussed with a stick, used in many Brazilian genres, including samba and choro.
} 
colocada. Se vê que a fala dele está muito ali, e é muito bonito. Eu gosto muito disso na música brasileira. O falar. Não necessariamente (sings) "Eu estou cantaaaando," e aquela nota que dura cinco minutos, né? (laughing) (Personal interview, June 15, 2015)

...I very much like to listen to Cartola singing. A lot. And I find it very atemporal and very modern, because it has a lot from speech. As much as he has some moments, he has vibrato, you know, it is a voice that a little bit placed. You see that his speech is very much there, and very beautiful. I like this very much about Brazilian music. The speech. Not necessarily (sings) "I am siiiiiinging," and that note lasts five minutes, you know? (laughing) (Personal interview, June 15, 2015)

Educator and musician Irajá Menezes, also raises speech as an important source of inspiration to composers:

O canto brasileiro, nos cem anos do século XX, ela é muito referenciada na fala. Aí a composição é muito baseada, é muito influenciada por isso. (Personal interview, June 22, 2015)

Brazilian singing, in the hundred years of the 20th century, is very much referenced in speech. So composition is very much based, is very much influenced by that. (Personal interview, June 22, 2015)

Vocalist Izábel Padovani has additional insight on the influence of the Portuguese language on Brazilian song. She believes that even her instrumental singing, or wordless singing, is Brazilian because it draws on the language. On occasion, Padovani is invited to participate in recording projects that require wordless singing. She says:

Eu acho que essa construção de uma prosódia que você constrói para cantar, por exemplo, coisa instrumentais, pra mim é muito brasileira. Minha voz faz isso de modo muito brasileiro. (Personal interview, June 29, 2015)

I think that that construction of a prosody that you build to sing, for example, instrumental things, for me is very Brazilian. My voice does this in a very Brazilian way. 
I asked her to describe to me what she meant by "a very Brazilian way." She replied:

Usando os vocábulos mesmo da língua. Porque a música americana, por exemplo, o jazz, vai ter uma escola de improvisação vocal, onde você até aprende aquelas pronuncias. E na música brasileira, a gente não tem improvisação vocal. A música popular brasileira, ela é a canção brasileira, mas não tem improvisação vocal. A tradição não é essa. E quando você pensa nisso, na essa improvisação vocal brasileira, no meu caso é bastante brasileiro. Não se parece nada com a música americana. Eu tenho vocábulo todo construído em cima da língua portuguesa. (Personal interview, June 29, 2015)

Using the very vocables of the language. Because American music, for example, jazz, will have a school of vocal improvisation, where you even learn those pronunciations. And in Brazilian music, we don't have vocal improvisation. Brazilian popular music, it is Brazilian song, but does not have vocal improvisation. That is not the tradition. And when you think of this, of that Brazilian vocal improvisation, in my case is very Brazilian. It doesn't resemble American music at all. My vocables are all constructed atop of the Portuguese language. (Personal interview, June 29, 2015)

Padovani's view is consistent with Machado's description of her perceived difference between a jazz singer and an MPB singer. ${ }^{34}$ Lívia Nestrovski, an emerging artist, living in Rio and working in São Paulo, also acknowledges this link between speech and Brazilian song: "A canção popular brasileira do século XX essencialmente tem muito a ver com essa questão do discurso. É o que o Luiz Tatit fala, e o Wisnik" (Twentieth-century Brazilian popular song essentially has much to do with that question of discourse. It is what Luiz Tatit says, and [José Miguel] Wisnik)(Personal interview, July 15, 2015).

The stage for MPB canon formation appears to me to have been set with the establishment of samba as of Brazil's national rhythm. Although one of the main

\footnotetext{
${ }^{34}$ Please see page $55-56$ of Chapter One.
} 
catalysts for this was the Vargas government's push for a unifying music (Vianna

[1995] 1999), the resulting acceptance of samba as a national rhythm, I believe, had an impact on the public's perception that such a thing should and could be maintained. In other words, in supporting a national music, the government also fed into an existing public desire for one, creating a value that has become so entrenched in the Brazilian culture that it is hardly questioned, thanks to the perceived loftiness of national pride. Anderson describes the naturalized sense of kinship that occurs in national identity construction. He relates this to language: “...there is a special kind of contemporaneous community which language alone suggests - above all in the form of poetry and songs" ([1983] 2006, 145). When the label Música Popular Brasileira appeared in the 1960s, the label itself, which pulls at the heartstrings of a people thirsty for a sense of national unity, was the perfect signifier for the broader musical category it has become. And its perceived connection to language is not accidental.

\section{National identity through mistura (mixture)}

One of the most salient elements in the self-definition of Brazilian culture is the notion of mestiçagem (racial mixture), or mistura. The dominant view during Brazil’s belle époque (1902-1916) was that African Brazil was antiquated and that it was better to pursue European models of civilization (Vianna [1995] 1999, 23). Then in the 1930s, with Gilberto Freyre's project of identity renewal, the notion of mistura became a powerful and enduring mantle upon which Brazilians could hang their identity. Vianna comments on Freyre's book The Masters and the Slaves: "It did 
not represent a return to roots so much as an imaginative recreation of those roots" ([1995] 1999, 41). Differentiating Brazilian culture from that of the metropole was a primordial feature of Freyre's work. And although the myth of racial democracy has been exposed many times over (Wong 2011, Santhiago 2011, Henry 2008), the idea of mestiçagem still underlies Brazilian identity in a way that consciously stems from the notion of three founding societal groups, namely Europeans, Africans and Indigenous. Vianna describes the trend in late 19th, early 20th century thinking on racial mixing in Brazil ([1995] 1999). He explains that most intellectuals were in agreement that what defined Brazil was racial mixture. Brazilian culture, however, was deemed to be "backward" and in need of "lifting up" by European blood. The African element in Brazilian culture was seen as indolent and inferior. And indigenous elements were not even considered Brazilian until the Romantics exoticized them. Before Freyre, most intellectuals favoured a "whitening" of Brazilian culture through eugenics (formal or not). Freyre, on the other hand, identified mestiçagem as a key defining feature of Brazilian culture, a notion that was politicized in contrast to segregation in North America (McCann 2004, 77). According to Vianna,

[Freyre] believed that a Brazilian aptitude for differentiation, for feeling "at home" with diversity, had origins that preceded colonization of the tropics, origins reaching back to the ethnic and cultural complexity of Portuguese historical experience at the gateway between Europe and Africa ([1995] 1999, 63).

This notion of mestiçagem (racial mixture), albeit problematic in many ways, continues to permeate MPB musical practice, even though indigenous cultural influence remains in the margin of popular music. And Africaneity, although still an 
economic and social disadvantage, holds the paradoxical position as the mark of Brazilian authenticity, so long as it is tempered by aesthetics stemming from Western European culture. The attachment to Africaneity as a form of authenticity is a sort of self-exoticism that was central to Freyre's identity project. Brazilians proudly maintain Portuguese and the mother tongue, and differ from surrounding nations of the Americas largely through language. In order to simultaneously differentiate from the motherland, while maintaining its language, many Brazilians cling to the notions introduced by Freyre, that hold mestiçagem up as the indicator of Brazilian identity. I heard many echoes of the value of mestiçagem in the discourse of contacts from São Paulo.

Música brasileira pra mim, o que me chama muita atenção são as melodias. Eu acho que essa mistura que é o Brasil. Acho que é como o Canadá. Uma mistura de raça, de cor, de som, traz essa riqueza melódica, que eu acho é muito bonito. Eu sou muito fã. (Amin, personal interview, June 15, 2015)

Brazilian music for me, what gets a lot of my attention are the melodies. I think it is this mixture that is Brazil. I think it is like Canada. A mixture of race, of colour, of sound, through this melodic richness that I think is very nice. I am a big fan. (Amin, personal interview, June 15, 2015)

Acho que a grande característica da música brasileira é a mistura. A gente começou misturando. E é o que a gente sabe fazer. Tem um tempero brasileiro até a gente mistura. ... É uma coisa que parece que a gente faz naturalmente. Então é engraçado. ... Como as coisas vêm, e a gente absorve, e já entrega uma outra coisa. (Horta, personal interview, May 12, 2016)

I think a big characteristic of Brazilian music is mixture. We began by mixing. It is what we know how to do. There is even a Brazilian spice that we mix. ... It is something we seem to do naturally. So it's funny... How things come, we absorb them, and then deliver something else. (Horta, personal interview, May 12, 2016) 
Social democracy has been discredited as a myth, because of continued evidence of racial discrimination. It nevertheless remains an ideal to which many MPB artists cling, and which they strive to embody.

\section{Canon Number 3: MPB as "quasi-popular music"}

As Connell and Gibson aptly point out: "There can be no formal definition of popular music" $(2003,5)$. Without attempting to define it, however, we can examine how it is used as a principle in the definitions of MPB. The "popular" in música popular brasileira doesn't refer to the number of albums sold. It does not refer to the popularity of artists in the sense of how many people attend their concerts, or the size of the venue necessary to accommodate their fans. The word popular in the label MPB is by no means a reflection of it having broad commercial appeal. It is more in keeping with Chasteen's definition of the word, wherein "popular" is different from the typical English usage, meaning "widely liked." He uses the term "popular" "in an older sense (still quite common in Spanish and Portuguese), in which popular relates more specifically to 'the common people'-as opposed to the elite or the middle class" $(2004, \mathrm{xi})$. At the time the term MPB emerged, as a form of protest song, it was important for this sense of the popular to come through, in opposition to the authorities that were being resisted. Additionally, as Cavalcanti explains, as a result of the success of bossa nova music, "artistas sem grandes recursos vocais, como Nara Leão, Geraldo Vandré, Carlos Lira, Astrud [Gilberto] e Chico Buarque também fizeram sucesso como 'cantores'" (artists without great vocal resources, like Nara Leão, Geraldo Vandré, Carlos Lira, Astrud [Gilberto] and Chico 
Buarque also made a success as "singers") $(2011,11)$. Even in the vocal technique of this music, or lack thereof, there was a sense of the sound of the common person. I will return to this point in the section on MPB as vocal music. The expression "quasipopular music" emphasizes the middle position of MBP between commercial popularity and popularity as in "of the people."

In his chapter entitled "Farewell to MPB," Brazilian composer and musicologist Carlos Sandroni points to three key events that lead to his declaration that MPB is no longer a relevant category. The first is his realization that in France (and presumably elsewhere as well), the term "popular music" holds an entirely different connotation than the way he had understood it growing up in Brazil. His contacts in France did not consider "popular" to apply to a composer and workcentred music, but rather to rural folklore. This is helpful in giving the perspective that definitions of "popular" differ around the world, but I do not presume the French definition is more, or less, valid than the Brazilian one. Rather, it represents another set of values that helps put Brazilian values of popular music into relief. Sandroni reminds us that use of the term "popular music" in Brazil has been modified significantly since the 1940s, when its meaning more closely resembled today's use of the term in France. Among others, he cites Mario de Andrade's work from the 1930s, which characterize popular music as predominantly rural, reserving the term "popularesco" for the urban variety. Between the 1940s and 1960s, there was a movement valorizing folkloric music, and contrasting it with the "popular" urban music. Sandroni points out that between Oneyda Alvarenga's book Música Popular Brasileira from 1947, and José Eduardo Homem de Mello's book by the 
same title from 1976, MPB transitioned from being considered a mainly rural music, to a mainly urban music. He states: "The term concluded its transition toward the current meaning" $(2011,67)$.

Sandroni states that in the 1990s, the category "MPB" began to be seen as a market label, in others words a genre label alongside samba and axé, among others in retail stores, which fragmented musical taste, rather than unifying it $(2011,70)$. Finally, Sandroni points to the integration of folkloric music into the commercial music realm in recent years as the final nail in the coffin of his conception of MPB (2011, 72). I would have to argue that the current notion of MPB need not be seen as a "conclusion" at all, particularly if MPB is viewed through the lens of canonicity, which resolves the issues Sandroni raises.

Canonicity highlights the unfixed, ever-changing understanding of what is and is not quality Brazilian music. It emphasizes the subjective nature of canon formation, and the myriad canonizers that are implicated in a fluid and dynamic interpretation of what is and is not MPB, depending on one's vantage point. An example of artist as canonizer is Gilberto Gil, who is quoted by Sandroni, saying: "There are several ways of doing MPB. I prefer all of them." Sandroni continues: "This was not merely a phrase with an effect. It shows that the acronym was intended to be unifying, and it was indeed able to unify" $(2011,70)$.

Sandroni's nostalgia toward an MPB that used to unify but no longer does, underscores the tension between commercialism and artistic value. Artists must participate in the economy in order to ascend to canonical status. They also need to make a living, while respecting their own artistic intent. The scattered genres that 
make up the MPB Canon indicate the multiplicity of viewpoints from which Brazilian popular music can be constructed.

I would submit that MPB is alive and well in smaller-sized performance spaces and in the hearts of many musicians in São Paulo, and presumably in the hearts of the patrons who listen to them. This particular scene is a middle-class environment, generally frequented by educated people. The enduring, albeit changing, existence of an MPB Canon is manifested by the continued success of institutionalized music programs that teach it. Viewing MPB as a set of canons renders evident the fact that MPB is an idea, a construct of national identity and "musical quality," that coagulates in the public imaginary in contested fashion. Who determines what and whom to include in the MPB canons is a broad range of canonizers, such as the authors, encyclopedias and artists cited by Sandroni. ${ }^{35}$

For the most part, proponents of MPB do not snub commercialism itself. Some celebrity artists, like Caetano Veloso, are able to draw huge audiences to a concert. However, since he is perceived to make quality music, his commercial success is not begrudged. Some independent artists in search of artistic integrity, such as Ná Ozetti from the Vanguarda Paulista generation, have made a point of functioning outside the purview of large-scale commercial music enterprises. However, as Mariz highlights, these artists are presented in SESC concert halls, receive remuneration, and sell discs, making claims of complete independence untenable (Mariz, personal interview, June 11, 2017). Perhaps it would be more accurate to say that making corporate-scale profits on music is not the primary

35 Please see discussion of possible canonizers on page 74 . 
motivation of many musicians, certainly those who choose a genre of music that is not likely to gain mass-market attention. But again, the reality and the desire are two different things. Artists Passos, Amin, Padovani, Machado and Gracelli, all lamented the fact that their style of music is not more widely appreciated, because they think of their music as having higher quality than most commercial profitable musics. They lament the poor quality of most commercially viable musics. The same situation can be observed in North American jazz circles (Beausoleil-Morrison 1999).

It is the purpose of every artist to reach as many fans as possible through their music, and many of my consultants actually bemoan the fact that MPB more broadly consumed than it is currently. At the same time, the commercialism that is the hallmark of pop music and sertanejo, is deemed distasteful. As the participants of VocalSP were quick to clarify, the type of commercial music from which they wish to distance MPB is what they describe as "música descartável" (disposable music), or as Jones may put it: music that does not stand the test of time. As one consultant explained: "A impressão que eu tenho desse tipo de música é que o compositor pegou uma sequência do qualquer, escolheu um 'loop,' fez uma partida legal, e ficou ali atando letra falando bobagem encima da uma partida" (The impression I have of this type of music is that the composer took someone's sequence, chose a "loop," made a cool chart, and was there attaching silly words on top of the chart). Another participant recounts a Facebook posting by a producer from a large American firm, speaking about "uma fórmula para compor músicas de sucesso" (a formula for composing hit songs)(Group interview, VocalSP, June 27, 2017). Although these 
criticisms of commercial pop appear to echo the views of Theodore Adorno, they also reflect a genuine concern for a type of music making that is well crafted and embodies artistic value. They value a musical experience that is intellectualized, as well as emotionally moving. Ethnomusicologist Kariann Goldschmitt notes: "While [bossa nova] still retains traces of its connections with social class differences and marketability, it is mostly music for listening without any signs of its novelty dance past" $(2011,72)$. This statement can be extended to the MPB Canon as a whole, music for sitting and listening, not for partying and dancing. This can be viewed as analogous to the $19^{\text {th }}$ century phenomenon, described by Talbot (2000), of European music moving from the social dancing and religious function, into the concert hall.

To pursue the relationship between the "popular" and música erudita (erudite music), the classical element that is sought after in MPB is not only an air of sophistication, but a substantial level of craftsmanship in melody and harmony, as found in Western European classical tradition (WECT). From a rhythmic standpoint, MPB could be said to stem from African-modeled musics, which as Packman (2011) demonstrates, have so often fallen within a "popular" realm, rather than the "erudite" domain. The "popular" in música popular brasileira is a reflection of what it is not. It is not música erudita. Once again, we are confronted with a paradox, that MPB is positioned to both approximate the aesthetics of classical music, and still distance itself from them.

The various meanings of "popular" indicate the very changing nature of the canons as they are passed from one generation to the other. The meaning of 
"popular" depends greatly on the context in which it is used, and the age of the person speaking it. Nevertheless, the term "popular" in "música popular brasileira" creates a simultaneous rapprochement and distancing from "erudite music," and a simultaneous rapprochement and distancing from pop music. This in-betweenness is the status, I think, that best defines this body of music. It is neither popular (in the commercial sense), nor does it aspire to the status of classical music. For this reason, it embodies what Machado jokingly referred to as "MQP: Música quase popular..." (Personal interview, June 23, 2015). In short, MPB is constructed as a "quasipopular" music of Brazil, appealing to an educated, yet hip, crowd. And some, like Passos, even advocate dropping the "popular" from the label altogether. She simply, yet emphatically, calls it Música brasileira (Public communication, June 22, 2015).

\section{Canon Number 4: MPB as Quality music}

In his presentation at Carleton University, entitled "The New Brazilian Popular Music," Álvaro Faleiros informed us: "The intellectuals are the creators and listeners of these musical-poetic compositions. A renewal in the aspects of harmony, melody, arrangements, instrumentation, and poetry [of] quality is produced" (March $22,2013)$. The notion of quality music has a lot of traction in São Paulo. Venues in São Paulo routinely advertise themselves as sites of "música de qualidade." One such venue is the Madeleine Jazz Bar, where a waiter handed me a market survey form. Along with the usual questions about demographic information, there were several questions directed at motivating factors in the client's choice of venue. The quality

of music presented was of particular concern, along with other factors such as an 
intimate atmosphere and good food. The survey manifested the bar's intention to provide a "high end" experience, which included quality music. Though it is tempting to paint this as a simple matter of snobbism and class-minded mentality, closer attention reveals a more nuanced perspective.

A question that was central to most of my interviews concerned what is understood as "good music." The answers I received were fairly consistent. Most consultants broke quality music down into its musical components, i.e. it is harmonically rich, melodically rich, rhythmically rich, and importantly, lyrically rich (Amin, Machado, Nestrovski, Menezes, VocalSP, personal and group interviews, June-July 2015). I pressed further and asked consultants what they thought rendered each component "rich." Most consultants required more prompting, because the discourse of quality is so entrenched that they thought it should be obvious to me. I asked: "Is it music that is difficult to play? Is it particularly complex in its composition?" And once again, my contacts responded with a high degree of consistency. None were willing to say that good music needs to be complicated or difficult, although it can be. It usually came down to immeasurable qualities, such as beauty, originality, creativity, variety, and above all the capacity to move the listener.

Part of the answer to my questions regarding quality could also be found in its opposite, "bad music," or what they call música ruim (literally vile or rotten music). Composer, vocalist and pianist, Beth Amin offers this explanation: [Gilberto] Gil é um ídolo pra mim. São nossos ídolos. Mas as pessoas estão envelhecendo. E eu acho que urge. Existe uma urgência de novas coisas. E as novas coisas que são comerciais, muitas delas, musicalmente, são inferiores à aquilo que essas pessoas fizeram. $O$ 
que está sendo feito comercialmente. Mas não existe um espaço. É difícil você conseguir um espaço pra mostrar outras coisas. ... A questão é: o que é veiculado no rádio, na televisão? E nem sei se é uma "droga," porque existem manifestações que são muito populares, como funk carioca, que é uma coisa que eu não suporto ouvir. Eu não gosto. É ruim musicalmente. As letras são péssimas. Mas é uma manifestação legítima do povo mais pobre do Rio de Janeiro. Então o funk hoje em dia, tem um espaço grande. A mídia toca bastante nas festas. As pessoas ganham dinheiro com isso. $E$ tudo bem. Eu não acho ruim. Eu só acho difícil, hoje em dia no Brasil, o que eu sinto é: não fazer sucesso é sinônimo de estar fazendo uma música boa. (chuckles) Uma música de qualidade, enfim. (Personal interview, June 15, 2015)

[Gilberto] Gil is an idol for me. They [canonical figures] are our idols. But people are getting older. And I think it is urgent. There is an urgency for new things. And new things that are commercial, many of them, are musically inferior to that which those people [canonical figures] did. What's being done commercially. But there is no space. It is difficult for you to get a space to show other things. ... The question is: what is being transmitted on the radio, on television? And I don't know either if it is a "drug," because there are very popular manifestations, like Carioca funk, that is something that I cannot tolerate listening to. I don't like it. It is musically vile. The lyrics are horrible. But it is a legitimate manifestation of the poorest people of Rio de Janeiro. So nowadays funk has a big space. The media plays it a lot at festivals. People make money with this. And it's all good. I don't think it's vile. I just think it's difficult, nowadays in Brazil, what I regret is: not making hits is synonymous with making good music. (chuckles) Music of quality, anyway. (Personal interview, June 15, 2015)

Like Amin, Padovani complains that the music she makes does not have the public it once did, largely because of a lack of media and commercial attention, which tend to favour fast turn-around and quick profits. Nestrovski concurs, noting that the "race to the bottom" of popular music found on the airwaves is not peculiar to Brazil:

Então quando eu pego material novo para ouvir, será que ela está bem produzido, está bem feito. Tem arranjos que são interessantes. ... E letras minimamente inteligentes. Mas as vezes aquilo ali não tem nada de se você tirar produção. Assim pra mim, eu sinto muito a falta de boas harmonias, de bons refrões, de boas melodias. Eu acho que 
tem uma tendência mundial assim. (Personal interview, July 15, 2015)

So when I take new material to listen to, it will be that it is well produced, well made. It has interesting arrangements. ... And minimally intelligent lyrics. But sometimes it doesn't have anything that you can take from the production. In my opinion. I very much regret the lack of good harmonies, of good refrains, of good melodies. I think there is a global tendency this way. (Personal interview, July 15, 2015)

Anthropologist, Falina Enriquez draws attention to the contradictions

inherent in musical genres that enjoy enormous commercial success (axé and brega) while being considered of poor taste and unworthy of state support $(2012,543)$.

Sean Stroud's study of Marcus Pereira's work offers hints of why that may be so.

Música Popular do Brasil ${ }^{36}$ seems to have come as a breath of fresh air to music critics, many of whom considered that Brazilian popular music was going through one of its periodic "crises of quality" in the early to mid-1970s. Pereira's desire to valorise the musical traditions of Brazil echoed many of their concerns about what they saw as the ongoing dilution of Brazil's musical heritage and the increasing domination of the airwaves and sales charts by imported pop, rock and disco. $(2006,311)$

Stroud's comments, coupled with consultants' expressions of the distance between commercially viable musics and quality, indicate a generalized anxiety regarding the dominance of Anglo-American pop, and its ensuing connection to commercialism and mediatisation, and their "dilution" of quality.

Whether a music is "rubbish" or "quality" music is in the ear of the beholder. Avelar and Dunn describe popular music in Brazil as "contradictory." It has been the

${ }^{36}$ Produced in the 1970s, Pereira's 16-album collection, entitled 'Música Popular do Brasil,' covers music from the Northeast, the Centre-west and Southeast, the South and the North, in four instalments. He continued the work of Mário de Andrade from the late 1930s in his Missão de Pesquisas Folclóricas (Folklore Research Mission), which mostly documented the music of the Northeast, as he believed it to be a source of the most authentic Brazilian music, untouched by foreign influence (Stroud, 2006, 305). 
site of the formation of what is socially accepted as "good" or "bad taste" $(2011,1)$.

MPB is often seen as antiquated by today's Brazilian youth, who tend to listen more to "global" genres like rock, hip hop, as well as sertanejo and axé, which, as Joana Mariz explained all begin to sound the same.

We have big artists, like Chico Buarque and Caetano Veloso, but usually MPB is less mediatic [sic], less television than the other genres we have in Brazil. And it's a mess, because even sertanejo... Sertanejo, some 10 years ago would be that same way of singing: (imitates caipira ${ }^{37}$ singing). But now it's not. Now it's just the same as American pop. It's the same. It doesn't change. The difference is people listen to it more in the countryside. And they use cowboy hats, and they identify with the countryside mood, the American countryside image. So, it's strange. Because it's not country. It's not like Willie Nelson. It's pop. Could be boys band, you know? (Personal interview, June 11, 2015)

Rosa Passos laments the fact that in Brazil today, bossa nova is generally misunderstood as "música do passado," (music of the past), while it is appreciated and respected in other parts of the world (Public communication, June 22, 2015). Connell and Gibson draw our attention to collective anxieties over foreign influence and the perceived threat of cultural extinction $(2003,119)$. They remind us that in the early twentieth century, middle-classes in many regions of the North Atlantic experienced a sense of "nostalgia for a world that had been lost" $(2003,36)$, prompting a desire to preserve a sense of definable identity at the national level. Bohlman highlights the fact that twentieth century predictions of music erasing national borders have not manifested themselves in reality $(2012,35)$. The MPB Canon presents itself as an antidote to the disappearance of Brazilian national culture in the face of global dominance by Anglo-American popular genres.

${ }^{37}$ Música caipira is "roots" music from the interior of Brazil, and considered the predecessor of sertanejo. 
Nestrovski also laments the absence of "difficult" 38 music. She has experience performing very complex and what we might call "inaccessible" music, to audiences that may not have the knowledge to discriminate it in such a way as to enjoy it. She focussed her attention on the performance aspect of that music because she finds that it brought an unusual music to a broad audience, even though it wasn't "pop." She has great respect for her public and maintains that if a music is popular and pleases the masses, who are we to say that music is not "good music"? She asks: is her music "good music"? (Personal interview, July 15, 2015). When I asked VocalSP whether "good music" is music that is difficult to play, they insisted that this was not the case. Perhaps good music need not be difficult to play, or to understand, but when music is difficult to play, a certain respect is given to the effort and care put into its creation by the composers, players, and arrangers. Generally, a product that is considered of high quality is one that lasts, that has been painstakingly created, and in the case of music, requires a great deal of training to play and to compose, with a great deal of thought, intention, expression, talent, skill, and training. How does one measure quality? No single element alone is responsible for quality, but rather a complex, and highly subjective evaluation.

The level of difficulty alone does not indicate the quality of the music, but neither is it unrelated. The effect of music that has been composed with intention, and thought, so as to create works that are less predictable, more intricate, with harmonies and melodies that do not necessarily follow a formula, with rhythmic complexity, is that they are more difficult to play. It is easier to play a piece when all

${ }^{38}$ By 'difficult,' she means difficult to play, but also difficult to listen to. 
the musical elements are predictable and common. So while difficulty may not be the goal, it is nevertheless sometimes a by-product of making well-crafted music. It may be unpalatable to some to embrace level of difficulty, because it tends to conjure up elitism. However, it seems to me that there must be a place for a diversity of genres and styles that appeal not so much to different classes of people, as different purposes, or different moments of the day or week, or year. Can one enjoy a painting in a museum that one may not necessarily want to purchase and put in one's home? Can one enjoy a live concert of music that is interesting, but that does not necessarily bear repetitive listening, or for that matter, listening without great attention? Some musics are more enjoyable when one's attention is on the music itself, and other musics are easier to appreciate while occupied by another activity such as dancing, or driving. There are musics that serve as comforting background in times of sorrow, grief, or simply while one is occupied with menial tasks. There are musics that help one concentrate on mental work. There are musics for every context and activity that do not necessarily limit themselves to a particular class of people. And any class of people may enjoy varying genres and styles, complete with varying levels of complexity and difficulty of playing and listening. Fast food contains high levels of sugar, fat and salt, because those are the basic tastes that humans crave. Similarly, fast music, or music that sells quickly, and pleases masses of people, will surely contain high levels of the ingredients that are palatable to them. Predictable harmonic movement, regular and simple rhythms, repetitive melodies with memorable hooks, all make hit music because they are easy to digest, easy to enjoy and easy to sell. But taste communities are not 
unidimensional. Theodore Gracyk posits that breadth of musical taste is highly correlated to educational level, with the more highly educated classes having the broadest of musical tastes and interests, and the lower educated classes having a narrower field of musical tastes $(2007,32)$. This, Gracyk notes, runs counter to Bourdieu's notion that elite classes favour classical music, while lower classes favour "popular music" $(2007,32)$. He also points out that an aesthetic experience is enhanced by depth of knowledge of any given music, that all aesthetic evaluations are not equal $(2007,194)$. MPB still has a loyal following, an audience that favours smaller, more intimate venues in urban settings. And perhaps they even like to boogie.

\section{Canon Number 5: MPB as vocal music:}

MPB is indissociable from song, and therefore, from the voice that carries it. This factor is so engrained in Brazilian culture that the voice is often taken for granted as an instrument, while paradoxically positioned as the centrepiece of the ensemble. In his presentation at Carleton University, Faleiros made the following statement:

As you know, the guitar is the most important instrument in the Brazilian popular music, which is the reason why Evandro Gracelli will explain to you some characteristics of this instrument in the Brazilian song tradition by playing to us some samples of these compositions during this conference. (March 22, 2013, emphasis mine)

This statement superimposes song and composition, and conflates MPB ${ }^{39}$ with "the Brazilian song tradition," but makes no mention of the voice as instrumental in its

${ }^{39}$ The title of the presentation is "The New Brazilian Popular Music." 
sound. Gracelli follows in the footsteps of many male composers who sing, but who have never trained the voice as an instrument. On the same day as this presentation took place, Beth Amin—a female composer, singer and speech pathologist—gave a presentation entitled “The Brazilian Way of Singing” (2013). Interestingly, Faleiros and Amin frequently work together as lyricist and composer respectively. Specialization in voice instruction nowadays is typically a female endeavour in MPB. Faleiros follows in the footsteps of Vinicius de Moraes, a giant of the MPB Canon, who is often cited as the person responsible for elevating lyrics in Brazilian song to a level of poetry. The role of the voice-and its attachment to words-is central, in part because of the high value placed on poetic lyrics.

The voice has always occupied an important part of Brazilian musical life. Fryer cites the travel notes of an American sea captain by the name of John Codman, who comments on a church service near Rio de Janeiro in 1866. Codman writes: "The words were African, with the exception of the chorus of 'Sancta Maria, ora pro nobis'...Music again, and that always vocal, while the congregation, standing, beat time both with hands and feet" (Codman, quoted in Fryer 2000, 60). Fryer articulates African elements in Brazilian popular music, emphasizing the vocal aspect:

Virtually all Brazilian popular music shares [systematized syncopation and frequent use of a flattened leading note], and much of it displays its African heritage in other ways, too: in its emphasis on percussion and dance rhythms; in its percussive approach to all instruments, including the human voice; in the off-beat phrasing of melodic accents; in a preference for "rich" or "rough" rather than "pure" tone (i.e. for a tone rich in upper harmonics, with a noise-tosound ratio higher than the European norm); in a texture of contrasting timbres, often polyrhythmically arranged; and in the 
frequent use of call-and-response patterns, often overlapping." $(2000,147-8)$

This description resonates with some of my conversations with consultants, who emphasized to me that a "good voice" in MPB need not demonstrate the kind of technique associated with Western classical singing. There is evidence that as of the nineteenth century, Western classical music took a turn toward valorizing absolute music ${ }^{40}$ above song. As Jones explains:

As the canon gained hold in the reception of classical music, complex instrumental music, proper reverence at concerts and scholarly writings were upheld as moral alternatives to the pagan social scene of opera, singing and dancing. These more "serious" genres gradually became valued over the hedonic. $(2008,16)$

Musicologist Gary Tomlinson notes Kant's position: “Song, music with words, must manifest a dependent beauty" (cited in Tomlinson 2012, 62). Tomlinson further explains:

Kant prepared the ground for the ennoblement of instrumental music through the nineteenth century that would take forms as different as the complexities of Wagner's relation to Beethoven or Hanslick's ... resolute separation of music from speech and musical from other beauty. $(2012,63)$

In many ways, MPB seems to embody a mixture of musical aesthetics, both European and African, which are occasionally in tension with one another, particularly as they are ascribed to different taste classes. Though the singing voice is sometimes associated with Africaneity, while instrumental music is equated with European tradition, I would submit that this may display a certain historical shortsightedness or cultural amnesia. Before the nineteenth century, European music

\footnotetext{
${ }^{40}$ Absolute music is instrumental music that is considered to be without extra-musical meaning (Dahlhaus 1989, 34).
} 
also had a culture of singing. Tomlinson notes: “... the presence of singing [is] at the heart of eighteenth-century accounts of the history of European society, of Europe's relation to other societies, and indeed of the origins of all societies" $(2012,61)$. However, as Fryer's description indicates, and my research upholds, there appear to exist streams of vocal approaches in MPB that are associated with either European or African aesthetic preferences.

Whether a person defends interpretation as an art form or not, it is clear that composition remains the height of artistic production, valued as Walter Benjamin may have described as the original or authentic authoritative voice ([1935] 2004). The interpreter is therefore borrowing from the author and developing the ideas of the "true author," and can be heard as reproducing the author's meanings, without owning them. I would argue that the interpreter is actually an author in her own right, engaging in Bakhtinian heteroglossia. Mikail Bakhtin states: "The word in language is half someone else's. I becomes 'one's own only when the speaker populates it with his own intention, his own accent, when he appropriates the word, adapting it to his own semantic and expressive intention" (Bakhtin, [1935] 2004, 677). We can extend this idea to music. To borrow Rosa Passos's expression, the intérprete must perform "sua leitura pessoal" (her personal reading) of a song (Public communication, June 22, 2015).

\section{Canon Number 6: MPB as a composer-centred practice}

The description of the Panamérica Canção Project presentations, given by Faleiros and Amin, at the beginning of the last sections suggests that there is a very 
strong current in weighting composition above performance in MPB discourse. This is in spite of the fact that the title of intérprete garners a good measure of respect in Brazil. Voice teacher Diana Goulart explains that in her experience, singers are highly regarded for what they do (Group interview with VocalSP, June 2015). I can personally attest to this, judging from the reaction I received upon introducing myself as a vocalist in São Paulo. On the other hand, although intérpretes are valued, there is often a tension between vocalist's performance practice, and the intention of the composer. As the members of VocalSP explained to me, some composers are sensitive about letting another singer record their songs, for fear that she will change something (Group interview with VocalSP, June 2015). They may refuse to let the singer change the key to accommodate her range, for instance. Or they may impose a condition on the use of their work. Vocalist, guitarist, and composer, Mônica Marsola cites a conversation with a composer, where he told her: "Não mude nem um acorde, nem uma nota, por favor" (Don't change a single chord, a single note, please). Marsola explains: “Aí eu comecei a trabalhar com enorme medo, né?" (And then I started to work with enormous fear, eh?). She goes on to recount that when she was working with a producer to record the song-a producer who is, himself, a “compositor e intérprete" (composer and vocalist)—she warned him "Não mexe em nada (Don't modify anything)." The producer in question assured her: "Não, mas eu posso. Porque eu conheço muito a obra dele. Vocês faz o que estou propondo, e nós vamos mostrar pra ele. Se eu autorizar. (No, but I can. Because I know his work. You do what I am proposing, and we will show him. If I authorise it). Marsola continues her story: 
Mas nem sempre você tem essa possibilidade, de modificar aquela canção e alguns acordes. E ele [o produtor] mudou ritmo, mudou a melodia, ele mudou a harmonia. Ele mudou a concepção inicial daquela canção. (Group Interview with VocalSP, June 2015)

But you don't always have that possibility, to modify that song and some chords. He [the producer] changed the rhythm, he changed the melody, he changed the harmony. He changed the initial concept of that song. (Group interview with VocalSP, June 2015)

This situation speaks to the hierarchy of authority that resides squarely with the men, who are the composer and producer, not the intérprete. And yet, at the same time, the very skill, indeed the job description, of vocal performers is their ability to interpret, in other words to make the song a unique experience in their performance of it. In the case of MPB, this seems to be a fine line for intérpretes to walk. They can alter the phrasing, notes, chords, keys, to suit their interpretation, within limits set by composers. Menezes illustrated this aesthetic to me through a description of why Brazilians prefer an Ella Fitzgerald approach to singing than Sarah Vaughan's.

Ella Fitzgerald é muito legal. Ela canta umas músicas muito legais. E ela faz a gente achar as músicas mais legais ainda. Então ela canta, ela improvisa, ela transforma, mas ela mantém aquele compromisso. "Eu não vou passar pra frente da música. Vou ficar igual. Eu não vou comer essa música." Ela não é mais importante que a música. Ela é tanto quanto. A Sarah Vaughan é maravilhosa. Não estou falando que não é. Mas Ella trabalha para a composição. No Brasil, a gente pega Elis [Regina], que ela trabalha muito para a composição. Só que ela, muito sabida, cantou muita música ruim. Músicas malfeitas, que ela fazia ficar maravilhosa. Ela era como quase uma compositora. (Personal interview, June 26, 2015)

Ella Fitzgerald is very cool She sings songs that are very cool. And she makes people think that the songs are even more cool. So she sings, she improvises, she transforms, but she maintains that compromise. "I will not pass in front of the music. I will remain equal. I will not eat the song." She is not more important than the song. She is equal to it. Sarah Vaughan is marvellous. I am not saying she isn't. But Ella works for the composition. In Brazil, people take Elis [Regina], because she works a lot for the 
composition. Only that she, very savvy, sang a lot of rotten music, poorly made songs, which she made marvellous. She was almost like a composer. (Personal interview, June 26, 2015)

Marsola's and Menezes's accounts would indicate that an intérprete can, and should, differentiate herself, but only insofar as it does not interfere with the supremacy of the composer, who happens to be male. This valuing of the composer above all, with the interpreter as a close second, is in direct relationship to aesthetics grounded in nineteenth-century European classical tradition. A turn occurred in European classical aesthetics with the Romantic period that began around 1800, changing the focus of musical authorship from a performer-based practice to a work-centred practice emphasizing composer supremacy (Talbot 2000, Middleton 2000). As Jones explains:

The rise of the composer-centred view of music coincided and correlated with the rising idea of the work-concept around the beginning of the nineteenth century, rendering the composer the most powerful figure in music and notated music more important that oral or improvised forms. Therefore, the single unit of any canon is usually either the artist/genius or "the work." $(2008,16)$

Musicologist Reinhard Strohm discusses some of the limitations of the work-centred approach, among them the excessive power for individuals, which obscures the collective action and production of musical works (2000). Simon Frith notes that generally popular music emphasizes the performing artist, while classical music tends to emphasize the composer (1996). He states: "My argument in this book is not just that in listening to popular music we are listening to a performance, but further that "listening" itself is a performance" $(1996,204)$. I would argue that both types of authorial focus, whether performance-based, or work-centred, have the same drawback of obscuring the one that is not in favour. In a composer-based 
practice, the performer's contributions are dismissed, and in a performance-based practice, the composer's work is overshadowed.

The MPB Canon places the composer at the very top, but leaves a limited space for interpretation. The punishments and rewards that are levelled at vocalists who disrupt the status quo in terms of composer-supremacy are rather insidious, and female singers are coopted into their own subjugation to male composers. At Rosa Passos's workshop, there was a broad range of levels amongst the participants. As noted above, Beth Amin, a seasoned composer and vocalist, offered to sing one of her own songs. When she was refused, she chose to sing "standard" tunes from the MPB repertoire, a samba by Chico Buarque and a ballad by Tom Jobim and Vinicius de Moraes. At the end of her performance, Amin expressed to Passos that her comfort level resides more in performing her own songs. Passos took her to task for this approach, denouncing the idea that a composer should sing their own songs, stating that this was an easier exercise than interpreting someone else's work (Public communication, June 24, 2015).

I found it quite contradictory that canonical composers should be revered to the point where the interpreter is not allowed to change so much as a gendered pronoun, while certain other living, breathing composers are told that singing their own songs is taking the easy way out. During the workshop, Passos claimed that singing someone else's songs is more difficult, and raises the artist from simple singer, to a higher designation of intérprete. Passos is an award-winning songwriter in her own right, but indicated that she prefers to have other people interpret her songs. As a performer, she has clambered her way to a respected position under the 
weight of the MPB Canon, which is dominated by male composers. Constructing an optic of interpretation as the height of vocal musicianship builds a space for women to participate in MPB in a respectable manner. Someone like Passos, who has been performing since the late 1960s, has a good deal at stake in elevating interpretive work. On the other hand, as Joana Mariz communicated to me: “Chico Buarque-é muito comum se dizer que 'é o melhor intérprete de suas próprias canções'” (Chico Buarque-it is very common to say that "he is the best interpreter of his own songs")(Personal e-mail, Sept. 9, 2016). It certainly appears that no one would be accusing Chico Buarque of taking the easy way out. But Beth Amin is not a canonical figure. And as a woman, Amin is expected to be an intérprete first of all, and a composer and instrumentalist, second and third, if at all. Her chances of establishing herself as a composer, and "the best interpreter of her own songs," are under a great deal of pressure. As she and Padovani both articulated to me on separate occasions: "Não tem espaço" (There is no space) (Amin, Padovani, personal interviews, June 2016).

This situation serves to highlight the particularly political nature of the Canon, and its covertly gendered criteria. Appealing to a standard of quality is a lofty way of protecting an existing Canon, elevating a practice by approximating nineteenth-century classical music values, while obscuring the hegemonic power of male musicians. In this way women are co-opted into their own oppression. It is worth noting that all but one of the participants in the Passos's vocal master class were women. I do not mean to suggest that becoming a vocalist is somehow a form of oppression in itself. Nevertheless, Fausto and Fausto explain: “... sexual 
discrimination in the workplace has not disappeared. Women have been largely restricted to what is known as 'women's work' [such as laundresses, domestic workers, nurses, clerks and secretaries] ([1999] 2014, 322)." The strength of an artist's position in the Canon is in direct proportion to their ability to fulfill its criteria. As a composer-centred practice, MPB effectively siloes women into the role of intérprete as another category of 'women's work.' This effectively limits women's ability to fulfill the canons as fully as their male counterparts. As mentioned by Karpinnen,

For a considerable stretch of time, canon-builders have been (mainly white, middle-class) men, who have worked to neutralise the exclusion of women from music. The canon of classical music tells us that there are no great women composers to stand beside Bach, Mozart and Beethoven, but it also serves to blur its own origins. $(2016,135)$

Similarly, women have had considerable difficulty being recognized for their participation in MPB, particularly with regards to their capacities in instrumental playing and composition. A handful of names, such as Chiquinha Gonzaga and Dolores Duran return time and again as the exceptions to the rule. In her work on Joni Mitchell, Karppinen discusses how women get excluded from the canon of popular music in North America:

... even more powerful than ridicule is the tactic of total disregard: pretending that women composers and performers simply do not exist or do so in remarkably small numbers. In narrowing the sample, the few women who do get written about come to represent an exception; paradoxically in them are then vested all the powers and potentialities of the female sex. If they succeed, they do so because they are exceptional and perhaps man-like; conversely, if they fail, they do so because they are women. (Karppinen 2016, 130) 
Ron Moy's in-depth study of authorship in popular music shows that authorship is assumed, assigned, and gendered (2015). Popular music specialist Roy Shuker has demonstrated the connection between authorship and fields of genre and canon (cited in Moy 2105, xiv). Both Amin and Gracelli's compositions were disallowed from the workshop because they were not part of the Canon of great composers. The cult of the composer is predicated on the premise that his authority is absolute. In the case of the MPB Canon the aesthetic that lingers is one that elevates it in relation to "low-brow" music, via a rapprochement to nineteenth-century Romantic values. However, as Strohm argues, one of the difficulties of the work-centred approach is that it fixates living culture. The collective imagination in Brazil has latched on to Romantic notions of composer and work-centred authority, and in so doing, minimizes the very real contributions, and musical know-how, of the vocalists who sing the nation.

Nicholas Cook examines a performance-based model of authority, which has surged in popular music criticism since the 1990s (2012). He states: "Fundamental to this expanded concept of performance is the idea that it generates meaning, rather simply reproducing a meaning that resides elsewhere" $(2012,185)$. This approach was further propelled, among others, by the work of Judith Butler that emphasized gender as performative in itself (cited in Cook 2012, 185). Cook writes: "The contemporary performance studies paradigm stresses the extent to which signification is constructed through the act of performance, and generally through acts of negotiation both between performers, and between them and audiences" (Cook, 186). This view contrasts with earlier notions of music as a work-centred 
practice. Citron states: "the public has probably had a hand in the movement from modernism to postmodernism-a shift that can be seen as a recognition that music is first and foremost communication between composer and audience" $(1993,28)$. Citron's discourse reveals her point of view as a musicologist of Western classical music, placing the composer as the top authority. I might suggest that a different economy of authorial status may be more productive. While the MPB Canon would suggest an attempt to place the composer as top authority, the study of vocal performance practice of MPB suggests that negotiation of meaning is rather triangular, involving a communication between composer, performers and audience.

\section{Conclusion}

Vocalist Izábel Padovani states:

As vezes eu acho que a gente tem que achar uma outra nomenclatura para essa música brasileira, para essa continuação da música brasileira dos anos 60. É assim, da continuação do Chico, do Tom Jobim, do Edu Lobo, do Milton Nascimento. Talvez hoje em dia posso chamar isso de música brasileira moderna. Mas de qualquer maneira eu acho que a raiz disso é a música popular brasileira. A MPB continua ser uma sigla, eu acho que representa essa música de qualidade, vamos dizer, que tem uma harmonia rica, tem uma melodia rica. Tem também uma letra que é essa coisa tão peculiar da música popular brasileira. Essa junção de melodia, harmonia e texto, com essa qualidade. (Padovani, personal interview, June 29, 2015)

Sometimes I think that we need to find another nomenclature for that Brazilian music, for that continuation of Brazilian music from the 1960s. It is this way, the continuation of Chico [Buarque], of Tom Jobim, of Edu Lobo, of Milton Nascimento. Maybe nowadays I can call this modern Brazilian music. But in any case I think that the roots of this is Brazilian popular music. MPB continues to be an abbreviation, I think, that represents that music of quality, let's say, 
that has rich harmony. It has rich melody. It also has lyrics that are so peculiar of Brazilian popular music. That junction of melody, harmony and text, with that quality. (Padovani, personal interview, June 29, 2015)

Padovani's eloquent statement articulates all of the canons I discuss in this chapter. She confirms that the individuals that made up the generation of original MPB artists from the 60s remain uppermost in musical esteem, and the list of artists she highlights are all male composers. She refers to the popular aspect, as opposed to classical, within the context of a music of quality. She also emphasizes the importance of the text, and in particular, the combination of text and music. This emphasis on the lyric indicates the intrinsically vocal aspect of MPB. Her choice of the word "modern" indicates that this music of quality differentiates itself from the initial TV MPB genre, yet grows out of this tradition. Ironically, before being cast as MPB, as Dunn informs us: "These new stylizations of bossa nova [second generation bossa nova] evolved into a category of song known as Moderna Música Popular Brasileira. By the late 1960s, this music was known simply as Música Popular Brasileira, or MPB" $(2001,56)$.

I have outlined in this chapter, a set of canons that together form the basis of MPB. Through the lens of canonicity, it is possible to observe how so many disparate genres can come to be included under one rubric. The MPB Canon includes key players-composers and intérpretes — that are clearly divided along gender lines. Examining the component canons of MPB allows us to answer some of the questions posed at the end of Chapter One. A canon of music need not be commercially viable in order to be used as a unifying force, and a source of national pride both at home and abroad. A composer-centred practice can create a space for the appreciation of 
performance, while at the same time keeping the performers in a strictly circumscribed role. A national music can borrow (in the linguistic sense) foreign elements, while maintaining its identity, despite its multiplicity. 


\section{Chapter Three: MPB Pedagogy}

Aside from performance itself, pedagogy is likely the most powerful way to transmit the canons of MPB to subsequent generations of musicians. How, when, and from whom singers learn their craft has a significant and long-term impact on the aesthetic choices they make throughout their careers. Emerging musicians owe at least some of their development to the serendipitous relationships with mentors that occur during their formative years. Music teachers pass on their philosophy and tastes, along with their musical knowledge, all of which have a profound impact on the careers, lives and futures of their students. By extension teachers have an effect on the quality and aesthetics of the music produced. Young students often adopt, and identify with their teachers' philosophies and continue to pass these on to their future students. Conversely, since teaching is one of the mainstays of musicians' activities, canonical material provide a useful framework upon which to base their curriculum. As Karppinen points out, "Without canons, we would be faced with a mass of cultural products through which all of us would have to find our way alone; hence for teachers and researchers, for instance, canons are a necessary tool" (Karppinen 2016, 135). Teaching and mentorship thereby serve as a vehicle for the construction, transmission, and also maintenance of the canons. Through pedagogy and mentorship, musical canons become self-fulfilling prophecies, allowing certain individuals or groups to claim hegemonic positioning and inherent value. Jones emphasizes the primary, albeit not exclusive, importance of educational institutions, in the formation of canons, stating: 
... institutions rely on canons for curriculum and prestige, while canons rely on institutions for their survival. ... Teachers most often use the same anthologies, textbooks and histories, both for reasons of examination syllabus and copyright, and this creates a common set of objects for study. $(2008,10)$

In the service of national identity, MPB constitutes a potent source of canonical material that can be passed to younger generations of students. The nationalistic aspect of this set of canons is the main fuel for its creation, dissemination and preservation. Jones offers:

As a consequence of being uniformly taught in schools, canons can promote nationalism and a sense of unity in a given society. ... while the full meaning for the canonical work is only thought to be understood by an elite minority of people, the value of the canon is supposed to apply to all. $(2008,11)$

Nationalism and the MPB canons are therefore mutually propelling. The desire for national identity motivates the construction and maintenance of a popular musical canon, even if the unity it provides is imaginary. And the existence of the canons impregnates the culture with a sense of national duty and pride. So even if MPB is not "popular" in the sense of numbers of adherents, it nevertheless has the power to represent the nation. And since the nation is so diverse, it is only fitting that MPB should be diverse in genre and style. Or to borrow Vianna's dictum, the MPB Canon shows "unity in its disunity."

As a hegemonic force, canons depend on self-effacement in order to be effective. As Karppinen points out:

Canons never speak of the conditions that shape them: instead of laying bare the cultural and societal forces that are at play in their formation, canons present works and artists by the virtues of their "genius", their "masterworks," their prowess and power. (Karppinen 2016, 135) 
Karppinen argues that canons perpetuate value systems that favour and represent a particular segment of society: "If the white, heterosexual, middle-class male is generally supposed to represent humanity, his tastes must also represent universal tastes" $(2016,136)$. Canons become the legacy that is transmitted to society as a whole, even though there is tension and resistance to it. For example, this is how female singer-songwriters are co-opted into maintaining a double standard that puts them at a disadvantage. This is the process in which teachers and mentors are, wittingly or unwittingly, participating. They are primary agents of the canons, or to use Jones's expression, they are the main "canonizers" (2008). That said, I would posit that the act of recognizing, and naming, MPB as a set of canons helps mitigate its hegemonic power. Canons can appear loftier if their criteria are left unexposed.

Although students will innovate upon the vocal approach of their teachers, the impact of teaching and mentorship cannot be over-emphasized. One of the results of teaching the canons can be described as a "genealogy" of singers. We can compare these genealogies to schools of thought, or "schools of singing" where cohorts, or "generations," of musicians relate to one another as a group. Machado gives the notable examples of Elis Regina's relation to Ângela Maria, of Gal Costa to Daiva de Oliveira and João Gilberto, and in turn of Marisa Monte to Gal Costa (2012, 22). Unlike family generations, which occur in life cycles of approximately twenty to thirty years, the boundaries of musical generations often refer to decades and follow the trajectory of genres or styles. For instance, the Vanguarda Paulista, a musical movement that emphasized ultra-high-pitched voices in women and growly, low 
tessituras ${ }^{41}$ for men, had their heyday in the 1980s. Although this style of singing is still practiced, it remains associated with the generation of musicians who innovated it at that time. Many Vanguarda Paulista artists are now mentors and models for the next generation, as teachers in private studios, music schools and university faculties. In fact, their students are now of age to hold teaching positions of their own. Bossa nova singing remains the strongest influence on the vocal approaches practiced in MPB. Based on approximately ninety solo "MPB" singers I heard in various educational contexts and performances in the São Paulo region ${ }^{42}$, I would venture to say that bossa nova singing has become the hegemonic style of singing. Mariz states:

We don't say someone is bossa nova anymore. No we don't. There is this genre of repertoire. "Now you are singing bossa nova." As Rosa Passos says: "Choose a bossa nova to sing." So there is a repertoire of bossa nova. But there is not a bossa nova singer in Brazil. (Personal interview, June 11, 2015)

The bossa nova style of singing is so engrained in the culture that it has become naturalized as "the Brazilian way of singing" (Amin 2013).

I do not intend to suggest that entire generations follow the same vocal approach, or that bossa nova singing is the only style practiced. However, there exists a strong affinity between mentors or teachers and their students. This affinity builds with time and becomes a canon in its own right; effaced, assumed, reified and nationalized. Through the mediation of teachers, students are put into virtual, if not actual, contact with their "idols" from the Canon, and can imagine themselves as part of a "blood line" of artists. This vertical identification, with previous

\footnotetext{
${ }^{41}$ 'Tessitura' denotes a vocal pitch range.

${ }^{42}$ Please see Participant observation section in the thesis Introduction, page 10.
} 
generations, combines with a horizontal identification between members of a given cohort. An individual's name then gets associated along both these axes, which propels their artistic and vocal development, and career trajectory, in its own particular way. Followers are not mere imitators of their mentors, but rather, motivated by the "possibility of immortality" 43 , young artists push the boundaries of a given style, in an attempt to make their individual mark. Increased training is one of the ways in which this is accomplished.

\section{Professionalization in MPB}

Following broader societal trends since the early twentieth century, the MPB community has undergone more and more professionalization as time passes. There are various levels of training available to MPB vocalists, from on-the-job experience to university level programs. Most artists participate in more than one of these levels. The existence of canons encourages more professionalization by virtue of the fact that there is a growing body of work to be studied, and therefore a more competitive field in which to enter. Forming a successful career path in music depends a great deal on an artist's ability to achieve canonical status, precisely because canons are the filter through which quality is assessed. Being regarded as a canonical artist is the ultimate dream of any musician with professional aspirations. And more and more, professional aspirations are pursued through formal academic musical study. Furthermore, through pedagogical channels, such as anthologies and

\footnotetext{
${ }^{43}$ See Jones, cited in Chapter Two, page 75.
} 
course curricula, works and artists achieve "omnisignificance" 44 , which is the selfperpetuating mechanism of the canons.

I witnessed this phenomenon in action in the MPB circuit of São Paulo. For instance, Irajá Pintos de Menezes is an independent teacher who visits elementary schools and does presentations about Brazilian popular music. His own training is in journalism, because, as he says: "No meu tempo não tinha faculdade de música popular" (In my day there was no faculty of popular music) (Personal interview, June 22,2015$)$. He began his university studies in 1980 . He describes his occupation as "musicalização infantil" (child music education), and works with children from babies to seven years of age. He sings with the children and plays guitar, teaching them through experiential means, rather than theoretical, although his goal is to teach them "os princípios da linguagem musical" (the principals of musical language) (Personal interview, June 22, 2015). He describes his research area as "a história da canção popular no Brasil" (the history of popular song in Brazil), and has given lectures on the voice in Brazilian popular song. Like many others, including intérpretes Padovani, Machado and Nestrovski, he started out playing in bars in his university days. At that time the only music option was "música clássica, música erudita" (classical music, erudite music) at Universidade de São Paulo (USP) (Personal interview, June 22, 2015). He opted for journalism and did his musical training at private music schools, namely Espaço Musical and Companhia das cordas, both schools where Gracelli currently teaches. As Menezes puts it: "Então eu fiz cursos livres de música. É uma formação normal de música popular. Não vai pra

${ }^{44}$ Please see Chapter Two, page 75. 
escola, né" (So I did independent music courses. It is a normal training for popular music. You don't go to school, eh?) (Personal interview, June 22, 2015). His would be the last generation for which popular music studies occur outside the university realm. His comment reflects a mode of learning from years gone by, when popular music was learned on the job, rather than through formal studies. Historically, it would have been assumed that popular music was more accessible than "erudite" music, and therefore did not require an academic or formalized training to pursue it. Popular music was the music of lower classes, and of racialized groups. AfroBrazilians would have been practicing genres such as samba, which would have been learned by ear and therefore dismissed by the ruling classes as easy to play.

The process of MPB resembles the rock and roll movement in the United States in the 1950s, characterized by young Caucasian males rebelling against what they would have perceived as old school conservative musical practices, and combining African American blues music with hillbilly traditions. Similarly, bossa nova was a movement of the same order, developing during a similar period as rock and roll, where young people from Rio de Janeiro with an European-style musical education, adopted a way of singing and playing that combined a singing style and technique typical of popular American crooning, adapted to microphone technology, with virtuosic singing techniques born of European emphasis on well-tempered tuning. It combined the complex rhythms of Afro-Brazilian music with complex harmonies of European traditions. The effect was to raise the status of popular music to a level that legitimated its acceptance as a topic of academic pursuit, one with a history and value system of its own, worthy of being passed down officially 
through institutional education. Positioning MPB as a music of quality is crucial to its survival in the institutional setting, even though it is still differentiated from, and unmistakably below the status of, classical music. This fact seems not only acceptable to its practitioners, but desirable, as one of the raison d'être of MPB is to distinguish itself from high-brow music. Instituting MPB in university level training is an important factor in the creation of an MPB Canon. Conversely, the existence of such a Canon legitimizes its position within the university system. This is a selfperpetuating set of forces that has led to an ever-increasing trend toward professionalization in MPB.

Although it is still possible for MPB musicians to practice their craft without ever setting foot inside a university, the trend has shifted considerably since Menezes was in training, to an emphasis on building an academic background along with applied musical training. I will now discuss various levels of training available to musicians in São Paulo, from university level degree training to on-the-job experiential training. I am fairly certain these levels of training bear a great resemblance to those available in other large centres, even though this study is focussed on São Paulo. The point of this exercise is to show how teachers and mentors transmit the canons of MPB, and to demonstrate how those teachings are both circumscribed by, and formative in, the canonizing process. Most (if not all) singers make use of more than one level of training, so we will see a great deal of crossover between these levels in the discussion that follows. 


\section{University level training}

Like Menezes, singers Regina Machado and Izábel Padovani, described to me that when they entered the university program to study singing in the early 1980s there was no such thing as a program for popular song (Personal interviews, June 2015). Machado, who is now a professor at UniCamp, and director of their popular singing program, reports that it was inaugurated at UniCamp in 1989, and was the first of its kind in Brazil. In the early 1980s, when Padovani and Machado began their singing training, if one wanted to study singing, the only option available was to study "canto lírico" (lyrical singing) or "canto erudito" (erudite singing). While Menezes opted for journalism combined with private music lessons, Machado and Padovani chose to train their voices in the classical field, even though their main interest was in popular music. I will discuss the use of the terms "lyrical" and "erudite" singing in Chapter Four. Machado explains that the program was inspired by Brazilians who traveled to the United States to study popular music in places like Boston's Berklee College of Music, and returned home with a new outlook on the place of popular music in institutions of higher learning. In its beginnings, the UniCamp program, offered training based on American idioms such as jazz and Broadway belting. When Machado became a teacher there, in 2002, she made a point of steering the program towards a focus on Brazilian music. She explains her reasons for doing so.

Porque eu nunca entendi, tendo a canção que a gente tem, por que eu vou estudar a música americana na universidade. Não tenho nada contra a música norte americana, muito pelo contrário. Mas não conheço ninguém, que foi pra Berklee estudar música brasileira. Não existe essa pessoa. Não existe esse curso lá. (Personal interview, June $23,2015)$ 
Because I never understood, having the songs that we have, why I would study American music in university. I have nothing against North American music, much to the contrary. But I do not know anyone who went to Berklee to study Brazilian music. This person does not exist. That course does not exist there. (Personal interview, June 23, 2015)

Machado believes that the program answers a demand for more professionalization in music. As she says:

Hoje existem várias [programas] mas a primeira foi na UniCamp. Isso acho que começou a contribuir ao sentido de possibilitar que os jovens pudessem ter uma formação acadêmica. Pudessem desenvolver um estudo formal. As escolas livres também, a partir dos anos 80 e 90, vão contribuir com a abertura desse espaço. Me parece que também vai havendo um sentido de profissionalização que vai gerando uma demanda de que se estude pra aquilo, né. Como se a ideia do especialista, num determinado assunto, requer um desenvolvimento mais formal. (Personal interview, June 23, 2015)

Today there are several [programs] but the first one was at UniCamp. I think this began to contribute to the feeling of making it possible for young people to have an academic background. They could develop a formal study. The private schools also, as of the 80s and 90s, will contribute with the opening of this space. It also seems to me that there will be a sentiment of professionalization that will manage the demand of what is studied for that, eh. As if the idea of the specialist, in a determined subject, requires a more formal development. (Personal interview, June 23, 2015)

Once again, one can observe in Machado's discourse how indissociable the voice is

from MPB. Not coincidentally, the UniCamp website places the voice in the same

category as all other instruments in their popular music program description.

A modalidade de Música Popular da Unicamp é pioneira no Brasil. Uma das grandes preocupações do curso é oferecer ao aluno as ferramentas necessárias para sua atuação profissional, em todas as especialidades possíveis da música popular, seja como instrumentista, arranjador ou produtor musical. ... O curso dispõe de professores de violão, guitarra, baixo, piano, saxofone, bateria e voz. (UniCamp, n.d.)

The modality of UniCamp's Popular Music is a pioneer in Brazil. One of the great preoccupations of the course is to offer to the 
student the tools necessary for professional actuation, in all possible specialities in popular music, whether it be as instrumentalist, arranger or musical producer.... The course disposes of teacher of acoustic or electric guitar, bass, piano, drums and voice. (UniCamp, n.d.)

Machado also talks about the necessity to maintain a focus for young students on listening to the tradition that precedes them. When I was at UniCamp in 2013, before offering a master class to the vocal students there, I attended Machado's listening session. Once a week, she holds a one-hour listening session, where she simply brings in recordings of singers from bygone eras, and introduces the students to the various ways in which the voice has been used throughout the history of MPB. Each term, she focuses the sessions on a particular period or decade of MPB. Besides the era designation on which the term is based, she does not talk very much about the history or context of the music, so much as the sound and singing style. For Machado, it seems, this focus on listening acts as a bridge between the young students' focus on academics and professional accreditation, and the application of the Brazilian popular singing tradition that she holds dear. Tradition, I notice, is often code for canons. This is not to say that canons are necessarily bad, but to label canonicity does call into question the means by which it has been established, and highlights its subjective and arbitrary nature. As we have seen, for canons to be most powerful, i.e. hegemonic, they require erasure. Machado's stated mission is to ensure that the traditions are passed down to the next generation, with a core value being national identity. Machado herself has achieved a Ph.D. level of education, in 2012. Padovani has just recently—in August 2017—completed a Master's degree at UniCamp. So although when they began their training, there was 
not possibility of pursuing popular music studies at this level, both these female artists have done so in mid-career.

The University of São Paulo (USP), Brazil's largest university, continues to offer a strictly classical orientation to its professional singing program. They also provide an "extensão" (outreach) program for amateur singers, including eleven choirs, involving approximately five hundred singers. In addition, they conduct "oficinas," or workshops, offered to amateur singers who do not succeed in their auditions to the choirs, and who would like to improve their skills in the hopes of gaining entrance to one of them. All of these components of the outreach program are free of charge to participants and are available to the public at large (Personal email, Amin, Dec. 13, 2016). Although this program does not count towards a degree or accreditation of any sort, it is a community service provided through the university.

While I was in São Paulo, Amin took me on two occasions to hear the $10^{\circ}$ Festival CoralUSP (10 $10^{\text {th }}$ CoralUSP Festival), where amateur community choirs from various institutions in the city gather to showcase their pieces to each other, to family, and friends. The event was free of charge. For each of the USP choirs, one person does the "preparação vocal" (vocal preparation) and another person conducts the choir in concert. Over the six choirs whose performances I attended, the women outnumber the men by a margin of two to one. The skill level of these choirs varied, but all of them had some intonation problems, which Amin was quick to point out after we left. She said that the choirs used to be better, and that the singers are not to blame. She thinks the directors should demand more. She 
explained that her job at USP is to give group lessons to singers of the choirs, because vocal development cannot be addressed in the choral setting. She said the men always have more problems with pitch than the women. I will return to the question of vocal skill and gender in Chapter Four. As well as being a composer, vocalist and speech pathologies, Amin, is a well-respected voice instructor who works with all of the eleven community choirs hosted by the USP in either of two capacities, namely as vocal instructor for group classes, and/or vocal preparation for performances. She also conducts the occasional "oficina," or workshop for potential choir members. Outside of her work at USP, Amin maintains a roster of students and speech therapy patients who consult her in a private studio. With the consent of her students, I was allowed to observe a full day of these sessions.

The repertoire presented at the $10^{\circ}$ Festival CoralUSP consisted of MPB pieces arranged for choir ${ }^{45}$, with a smattering of jazz. The pairing of MPB with jazz is a common, and not coincidental approach in São Paulo venues and presentations. Of the six choirs featured in the two evenings I attended, only one presented a full program of music outside of the MPB canons. The following are three project descriptions from the program notes of 10 o Festival CoralUSP, June 15, 2015,

1. CoralUSP 12 em Ponto:

O projeto apresenta diversas manifestações musicais da MPB dos anos 70, como música de protesto, black music, música com sotaque regional, $O$ Clube da Esquina ${ }^{46}$, disco music, rock alternativo, $O$ Grande Barato Místico, a retornada do samba e do choro. (June 15, 2015)

\footnotetext{
${ }^{45}$ USP has professional arrangers on staff to provide scores for all the choirs. These arrangers receive a salary, but no royalties.

${ }^{46} \mathrm{O}$ Clube da esquina was a 1970s collective of musicians (all-male) from the interior of Brazil, mostly Minas Gerais state, who modeled themselves after composer-singer Milton Nascimento (Severiano 2008, 425).
} 
1. CoralUSP 12 em Ponto (The USP 12-o'clock Sharp Choir):

The project presents various musical manifestations of MPB from the 1970s, such as protest music, black music, music with a regional accent, $O$ Clube da Esquina, disco music, alternative rock, $O$ Grande Barato Místico, the return of samba and of choro. (June 15, 2015)

2. Cantando no Quintal:

A cada ano é desenvolvido um repertório novo, com temas que são escolhidos pelo grupo. Depois de cantar a obra de Vinícius de Moraes (2013) e canções sobre o tempo (2014), o coral desenvolve, em 2015, um repertório composto apenas por canções de compositores nordestinos, com o objetivo de mostrar um pedacinho da beleza e versatilidade da obra por eles produzida. (June 15, 2015)

2. Cantando no Quintal (Singing In the Garden):

Each year we develop a new repertoire, with themes chosen by the group. After singing Vinícius de Moraes (2013) and songs about time (2014), the choir develops, in 2015, a repertoire comprised strictly of songs by Northeastern composers, with the objective of showing a small sampling of the beauty and versatility of the work they produced. (June 15, 2015)

\section{Grupo ACORDAVOCAL:}

Nestes 22 anos de existência o ACORDAVOCAL tem contabilizado em seu currículo inúmeros concertos dentre e fora da Universidade, desenvolvendo repertórios temáticos de musica popular brasileira e trabalhos de música erudita, com peças do repertório tradicional para coro, solistas e orquestra, visando um maior aprimoramento técnico-musical de seus integrantes. (June 19, 2015)

\section{Grupo ACORDAVOCAL (THEVOCALCORD Group)}

In these 22 years of existence ACORDAVOCAL has counted numerous concerts in its curriculum within and outside the University, developing thematic repertoires of Brazilian popular music and works from erudite music, with pieces from the traditional repertoire for choir, soloist and orchestra, aiming for technical and musical refinement of its members. (June 19, 2015)

Additionally, the Trato do Tom ${ }^{47}$ ensemble describes itself as eclectic in its beginnings, but gradually focusing on MPB (Program notes, 10o Festival CoralUSP,

${ }^{47}$ The name Trato do Tom can be understood as a play on words, denoting either 'Having to do with Tom [Jobim]' or 'Having to do with tone.' 
June 19, 2015). The values discussed in the context of MPB canons in Chapter Two are expressed openly in these project descriptions. They display a desire to foreground a national repertoire of quality, occasionally highlighting certain canonical figures, and also grounded in regional authenticity. The importance of the voice, and vocal competence, in a refined Brazilian music is also evident. The descriptions position MPB vis-à-vis popular manifestations that are associated with "black music", and work-centred classical music from an unnamed, but implied hegemonic "white" cultural tradition.

As mentioned earlier, USP does have a professional vocal program, but it focuses strictly on "canto erudito." Amin explains: "They don't have Brazilian music." According to her, this is a shame, and is very "colonial" (Personal interview, June 19, 2015). Amin's discourse shows a clear delineation between so-called "erudite" music and "Brazilian" music, even though there are Brazilian composers who have followed the European model of composition, such as Heitor Villa-Lobos. The canon of MPB serves as more of a Brazilian identity marker, while the work of Brazilian composers of the classical idiom may be a source of pride, but are not composing what Mariz refers to as "a música que nos identifica" (the music that identifies us) (Group interview, VocalSP, June 27, 2015).

Keeping in mind that USP is the largest university in Brazil, indeed in all of Latin America, the fact that it offers a strict focus on classical singing is not insignificant, and speaks to a lingering Eurocentrism that is enshrined in musical institutions of higher learning. Popular song, which can be said to be more in keeping with African traditions in many ways, has only been receiving institutional 
support since UniCamp instituted its popular music program in 1989. It is worth noting that while USP focuses on classical music in its professional program, the amateur choirs seem fully committed to popular musics, even though choirs have traditionally been associated with church music and classical repertoire. The mixture of a typically high-brow ensemble type and middle-brow popular repertoire creates a sort of middle-class hybrid of musical performance, reinforcing the canon of MPB as the middle ground between pop and classical idioms, or "quasi-popular" music.

At the university level, several privately owned Faculdades ${ }^{48}$ also now offer programs in popular singing. Two of the main such institutions in São Paulo are Faculdade Santa Marcelina and Faculdade Cantareira. I offered master classes at both these institutions, which gave me a glimpse of the kinds of vocal concerns brought forward by the students. I attended a full day of final MPB vocal performance exams at Santa Marcelina, and spent another day there, observing private voice lessons offered by Joana Mariz. Santa Marcelina is one of the foremost institutions for vocal arts in São Paulo. Mariz's first students were what she called "classical" singers. She was teaching them in a "classical" mode, which for her is a specific technique. The repertoire I heard that day was "Ouve o silencio" by Claudio Santoro, lyrics by Vinícius de Moraes. Mariz said it was "pre-bossa nova" and “erudite," from the 1950s. The second student sang "Martírio” by Osvaldo Lacerva.

${ }^{48}$ A faculdade in Brazil, besides the meaning that corresponds to the English 'Faculty,' also refers to a university level institution that is focused on one, or a very limited number of disciplines. 
Mariz said: "He writes in Brazilian scales. ${ }^{49 "}$ The text is by poet and Benedictine monk Luís José Junqueira Freire. Although the authors of these pieces are Brazilian, the music they produce is thought of as belonging squarely in the "classical" tradition, and outside of what is categorized as MPB. One student sang "Chanson d'amour," by Gabriel Fauré. Mariz asked me to help with French pronunciation, since I am francophone. She made sure I knew that in classical singing, they learn to make "r" sounds with a roll of the tongue, not the guttural French "r." When I corrected the student's French "u" sound, Joana called it " 'u' com boca de beijinho" ("u" with mouth in the shape of a little kiss). The impression I received from observing the lesson was that Mariz had a specific curriculum design in mind as to what consisted of correct classical technique. Although she was happy to have the help of a native speaker, my advice was filtered through her expectations of what is proper classical singing. Mariz seems to function with a clear delineation between classical and popular singing, but admits to a degree of questioning of these divisions. When I commented on how easily she taught students who sang different genres, she replied: "Not really. I can only do two styles." I asked her what those styles were. And she said, with a laugh:

MPB, which can be anything, and classical. The belty thing, I can advise people, but I can't really do it.... I imitate a little just for fun, but it's not really my thing. My thing is more bossa nova, I think, if this is the style? I don't know. It's very confusing. I have to read your work after you've interviewed people because I have to discover what's going on (big laughter). (Personal interview, June 11, 2015)

${ }^{49}$ By Brazilian scales, Mariz refers to "modal scales used in Northeastern folklore (mixolydian, lydian, dorian, and mixolydian with an augmented 4th)" (Personal e-mail, Feb. 17, 2017). 
Besides the academic training and vocal development from community choirs, the networking that happens at the university level seems to be the most enduring, with cohorts of students forming lasting professional working relationships, having spent a number of years studying together. Singer Lu Horta reported that her group Barbatuques came together during her university days at UniCamp. Lívia Nestrovski's contact with Vanguarda Paulista composer Arrigo Barnabé, among others, while she was at UniCamp was a particularly formative experience. Both Horta and Nestrovski met their life-partners during their university days, and married a person with whom they still make music as professionals. This brings me to a point that I should not skirt around. It is not unusual for the female vocalist to eventually marry one of the musicians in the band. Since women are more often than not in the minority within the context of bands, it is not terribly surprising that they would end up in a relationship with one of the other members. The intimacy of music making, the late and long hours of practice would all seem to lend themselves to personal connections being made. And in practical terms, these relationships facilitate a life in music, which tends to involve travel and flexible working hours. And while women used to have to choose between family and a career in music, it is now much more feasible to have a family with a partner that shares the familial responsibilities on the road. This is the case for Horta and her husband and drummer Marcello Effori, who toured to Canada and Europe in the spring of 2016 with their daughter. The social aspect of the university experience is not to be minimized, nor is the opportunity for professional networking. As Jeff Packman points out, musical networking and the private lives of Brazilian musicians are 
intimately linked (2011), and the university setting is more and more a place for that fulfillment.

\section{Independent music schools}

There are many small, privately owned music schools in São Paulo, where qualified musicians offer a vast array of private and group classes. Some of them have a reputation as being particularly good schools, such as Espaço Musical, owned and run by Ricardo Breim. Horta spoke about her time studying composition with Breim himself, and the value that had in her career trajectory (Personal interview, May 12, 2016). Gracelli teaches guitar at this school as well as others in the city. Gracelli accompanied me in giving a lecture recital at Espaço Musical in 2012. Breim himself was in attendance. His presence was considered a great honour to us, and he even joined us in performing a song. These types of schools are businesses that cater to all levels of musical ability and ages, and a common place for parents to send children for private lessons. And along with working in smaller private music schools, many musicians give private lessons in their homes. And while private lessons are a perennial part of the learning path for all professional musicians, there is more and more of a trend toward obtaining a university level degree.

Private schools such as Espaço Musical and Machado's school, Canto do Brasil, have made a space for popular singing in their curriculum since the 80s and 90s. And like Machado, Espaço Musical emphasizes the listening aspect as the basis of musical development, as evidenced by this promotional statement describing the objective of the school: 
Em todos os lugares existem pessoas que aprenderam a cantar, tocar um instrumento, compor ou improvisar, a partir do contato direto com a música de sua cultura. Escutando, imitando e reproduzindo, puderam desenvolver e aprimorar aquilo que no Espaço Musical chamamos de percepção musical básica. A experiência mostra que a música é um conhecimento acessível a todas as pessoas que tem a oportunidade de contar com a orientação que lhes é adequada. No início só pode ser aprendida pela escuta, como a língua materna. Mas, a partir dessa aprendizagem, uma educação musical especializada pode transformar a percepção básica em uma percepção da música como linguagem - algo que se pode desenvolver juntamente com as competências mais elaboradas para compor, interpretar e improvisar. (Espaço Musical, n.d.)

Everywhere there exist people who learn to sing, to play an instrument, to compose or to improvise, beginning with direct contact with music from their culture. Through listening, imitating and reproducing, one can develop and refine that which at Espaço Musical we call basic musical perception. Experience shows that music is knowledge that is accessible to all people who have the opportunity to count on adequate guidance. In the beginning one can only learn through listening, like a mother tongue. But, from this learning, a specialized musical education can transform basic perception into perception of music as a language - something that can develop along with more elaborate competencies to compose, interpret and improvise. (Espaço Musical, n.d.)

What emerges from this statement is a much more structured approach to musical training than may have been associated with popular music in the past. Prior to the 1980s, popular music was primarily driven by on-the-job experience and self-study. As the history of Espaço Musical elucidates:

No final dos anos 1960, muitos dos jovens que se interessavam em aprender música estavam motivados pelas canções populares e músicas instrumentais produzidas na época. Na cidade de São Paulo, as escolas de música ainda não sabiam que estava surgindo um outro tipo de organização do que é conhecimento em música, que valorizava as competências para tocar de ouvido e improvisar. Ofereciam apenas um ensino dividido entre teoria e prática, referenciado principalmente na leitura e interpretação da música de concerto. 
Vinte anos depois, mesmo com as novas propostas, o acesso a um conhecimento musical mais significativo só se mostrava possível aos poucos alunos que já traziam uma experiência pessoal mais relevante para escutar e tocar de ouvido. (Espaço Musical, n.d.)

At the end of the 1960s, many young people who were interested in learning music were motivated by popular songs and instrumental music produced at the time. In the city of São Paulo, music schools still did not know that there was another type of organization of musical knowledge surging, which valorized playing by ear and improvising. They only offered a split course between theory and practice, referenced principally in reading and interpretation of concert music. (Espaço Musical, n.d.)

To paraphrase Espaço Musical's website, what they provide is a blending of approaches between the conventional structure of classical music studies based in theory and practice, with aspects of popular music such as improvisation and playing by ear. This teaching philosophy creates a rapprochement between "erudite" and "popular" musics that has the effect of elevating the study of popular music to a canonical level, without compromising the notion of classical music as the summum of musical training. In essence, it establishes popular music of quality as a middle ground between facile pop and classical music.

In her capacity as owner-founder of private music school Canto do Brasil Regina Machado safeguards a canon of Brazilian song in which intérpretes are the primary authority. For her, singing is at the heart of Brazilian popular music, and is in itself a tradition to be upheld. She makes no apology for her school's purpose to uphold a national tradition based, as she says, largely but not solely on a particular singing style-bossa nova-that was originally a localized musical practice of mostly middle-class young Euro-descendant men from Rio de Janeiro in the 1950s and 60s. Machado also plays guitar, and used to give guitar lessons, but she decided 
to let that go in favour of concentrating on voice teaching. Like Passos, who vehemently defends vocal interpretation as the height of vocal musicianship, Machado has dedicated herself to the vocal aspect of MPB. Raising the profile of interpretation is a strategy that implies a concurrent raising of women's status within the hierarchy of MPB canons. It is important to note the role of the smallscale pedagogical institutes in establishing and maintaining national identity construction through the canons of Brazilian popular music. For better or worse, Canto do Brasil and Espaço Musical can be seen as a microcosm of the gendered division of labour in MPB. Composer Ricardo Breim's focus is on composition and instrumental playing, with a place for vocals in his school, while intérprete Regina Machado has an entire school dedicated to the voice. In her championing of the vocal arts in MPB, Machado is at once resisting and buttressing the existing MPB canons of vocal music in a composer-centred environment. This does not indicate any weakness on her part, quite the contrary. It does, however speak volumes about the strength and tenacity of the canons.

\section{Private teaching studios}

Private music schools, such as those discussed above, are bricks and mortar business locations that can accommodate private and group classes covering a range of topics, with several teachers working simultaneously. On the other hand, many individual teachers maintain a roster of students in their own private space, whether it be a single rented studio, or one inside their home. Amin rents a commercial space where she gives private lessons, while Mariz has a dedicated 
room inside her house, where she practices herself and gives lessons. As we have seen, these individuals are heavily involved at the university level, but they also participate in a more private sphere of teaching. The notions and expertise they bring to their students on university campuses are also transmitted to students seeking private instruction. Some such students have professional aspirations, and are complementing their experience with further vocal study, while others simply wish to improve their singing as a matter of personal enrichment.

In terms of repertoire choices, the private teachers I spoke to generally leave the repertoire choice up to the students, while guiding their selections based on the level of difficulty, or building a specific skill (Amin, VocalSP, personal and group interviews, June 2015). I spent a day in Amin's studio, observing private lessons from a variety of students. I also spoke to Amin about the repertoire choices. Although she lets her students choose to a certain degree, there are styles of music that she is not fond of and tries to avoid, such as Carioca funk and modern sertanejo. As we saw in Chapter Two, these are genres that do not usually belong to the canons of MPB, but are considered to be commercial genres, heavily influenced by American styles. This combined with their being perceived as having facile lyrics, oversimplified melodies and harmonies, mean that although they are sung in Portuguese, they are nevertheless excluded from MPB. In short, they do not fulfill the canons of MPB.

Amin tells the story of a twelve-year-old student who only wanted to sing and listen to Anglo-American pop music. Amin spoke to the mother and told her that the girl was too young to not be exposed to "música brasileira" (Brazilian music). 
She adds: "E eu como professora, se eu não dê isso pra fazer, eu não vou estar sendo uma professora certa" (And I, as a teacher, if I don't give her this to do, I am not being a good teacher) (Personal interview, June 15, 2015). So Amin assigned a Caetano Veloso song, and was dismayed that the child was singing it with an English accent. She says:

E ela não ouvia. Não ouvia! Então é muito difícil trabalhar com esses adolescentes porque eles não escutam. Então todo passar por esse filtro, dessa música [americana] e vira isso. É uma coisa pasteurizada que está endurecendo ao ouvido, por que eles não conseguem ouvir cromatismo. Não escutam cromatismo! Porque a música pop, tudo bem, tem coisas que são legais, mais ela é pobre melodicamente, harmonicamente muitas vezes. Então a pessoa que não consegue, não escuta cromatismo. Então é tão difícil, né? É uma coisa que dá um certo desânimo até. (Personal interview, June 15, 2015)

She didn't hear it. Didn't hear it! So it is very difficult to work with these adolescents because they don't listen. So everything passes through this filter, of this [American] music, and it turns into this. It is a pasteurized thing that is hardening the hearing, because they cannot hear chromaticism. They don't listen to chromaticism! Because pop music, it's all good, there are cool things, but it is poor melodically and harmonically much of the time. So the person cannot, doesn't hear chromaticism. So it is so hard, eh? It is something that is even a bit discouraging. (Personal interview, June 15, 2015)

For Amin, it is a question of developing the competencies necessary to measure up to a music of quality. And learning material from the MPB Canon is key to achieving competency. Some musical material from the Anglo-American tradition is acceptable, particularly anything by the Beatles, and anything that is considered jazz. In her studio, tellingly, Amin has posters of Elis Regina and Tom Jobim's influential duo album, and of Billie Holiday and Louis Armstrong. She is not the only teacher who favours Beatles repertoire when students want to do English material. Menezes also mentioned the Beatles as his go-to English repertoire. And I did notice 
that in Brazil, or at least in the Rio-São Paulo corridor, the Beatles still enjoy a very high profile as one of the principal references from the English speaking music world. One of the elements that distinguishes Brazilian repertoire of quality from others is the use of a great deal of chromaticism, combined with extended harmonies typical of jazz repertoire.

In short, private teachers uphold the canons of MPB via repertoire choices, and via a standard of quality that they wish to achieve. Some of these pressures are related to a desire to align oneself to a repertoire of quality, in order to maintain a good reputation as an artist and as a teacher. The canons provide a framework within which to choose appropriate repertoire and to associate with artists of renown. Furthermore, to be a representative of the nation in the musical act, holds a particularly compelling attraction to those seeking to belong to the middle class habitus.

\section{On-the-job training and self-study}

No matter what other training a singer receives, the experience of performing is a potent training ground. This was the most important training ground for musicians from the earlier part of the twentieth century until the 1980s. While the trend has shifted to favour formalized training, many artists still working today come from an era when self-study and on-the-job training were the norm. Several of my interlocutors remember a time when there simply was no program of popular music studies available in an institutional setting. They began their careers by working in 
bars and venues and learning "the old-fashioned way." Passos is one of those people who learned by lived experience and through self-study, the benefits of which she did not fail to drive home during her master class. The difference in training grounds is perhaps the largest gap between generations of MPB performers, a factor that, I suspect, may be reproduced in many other musical communities.

The early part of the twentieth century was by no means friendly to women who wanted to make music their careers. Participation in popular music would have then required admittance to a network of musicians who would meet in locations that may not have met with parental or societal approval. The music would be performed into the wee hours, adding to the image of low respectability. Women who participated in what was considered a lascivious lifestyle were therefore considered little more than prostitutes and condemned by their communities if they chose to prioritize music over founding a family of their own. Gradually, the fact that women gravitated toward the voice as the instrument of choice is not surprising, given that the pressure of being in the home was so great. As Post shows us, women all over the world have been the primary caregivers, and as such, required their hands to be free to conduct household chores, nurse, carry and care for babes and elders $(1994,38)$. They also did not have the time to practice an instrument, as their familial duties prevented them from prioritizing activities of their own. The solitude required to perfect instrumental technique and composition was not part of most women's life-scape $(1994,40)$. Singer, composer, guitarist Mônica Marsola recounts these kinds of pressures:

E estudar um instrumento, é muito empenho. É muito trabalho. E as mulheres têm essa função, pra gente, só você vê, vai. Ela faz uma 
opção. É uma carreira muito sofrida por uma mulher. Porque todas as mulheres sempre tem culpa [laughter from others]. Então tem essa questão. Então minha filha fala: "mãe, você é perversa." Se uma mãe é perversa, quer dizer que eu subverti as ordens. "Mamãe você sempre fez tudo que nenhuma mãe faz." Para conseguir continuar cantando, continuar tocando, eu precisei abrir mão de muitas coisas na minha vida pessoal. (Group interview, VocalSP, June 27, 2015)

To study an instrument is arduous. It is a lot of work. And women have this function for people, you can just see it. They make a choice. It is a very suffered career for a woman, because all women always have guilt [laughter from others]. So there is this question. My daughter says: "Mom, you are perverse." If a mother is perverse, it means that she subverts the order. "Mother, you always do everything that no mother does." To be able to continue singing, to continue playing, I needed to sacrifice a lot of things in my personal life. (Group interview, VocalSP, June 27, 2015)

The conversation turns to Rosa Passos, and how she began her career late because she had children first. However, marrying a man who had a good income permitted her to dedicate the time to her musicianship in a way that many women cannot fathom. Marsola continues:

E depois ela[Passos] foi seguir a carreira dela. Então ela não tinha essa preocupação da sobrevivência. Agora, nós mortais têm que suprir a sua familia, e ganhar grana. Isso tira do seu... estuda menos. Ela estudava seis horas por dia. Eu comecei a estudar duas. E a mulher estuda amamentando, estuda no hospital. Estuda do qualquer jeito, entendeu? Os homens nnn... né. Acaba uma questão social mesmo. Ficou pouco liberados dessas coisas. (Group interview, VocalSP, June 27, 2015)

And then she [Passos] followed her career. So she didn't have that preoccupation of survival. Now we mortals have to provide for our family, to earn money. This takes away from her... she studies less. She studied six hours a day. I started out studying two. And a woman studies while nursing, she studies in hospital. She studies in any way, understand? Men, nnn... no. It ends up being a real social question. We are not liberated from these things. (Group interview, VocalSP, June 27, 2015) 


\section{Workshops, master classes}

As a Canadian in São Paulo, I was struck by the existence of a vocal philosophy that generally regards the voice very highly as a means of musical expression, and the primary vehicle for the literary level of poetry expected in MPB. In line with this vocal philosophy is the very close connection and collaboration between teachers of voice and speech pathologists. Body centred, scientifically based voice work is prevalent in São Paulo, with a focus on quality that I have never witnessed in the Canadian popular singing environment. I will discuss further what is considered to be a "good voice" in MPB in Chapter Four. For now, I must underline the great many workshops, master classes and conferences available to São Paulo singers of all levels, and their impact on the formation of the canons of MPB.

An intitiative of Mônica Thiele, VocalSP is an association of voice professionals of all sorts in São Paulo and the surrounding region, which includes the city of Campinas - the site of UniCamp. Most of the members of VocalSP are performers. All are singing teachers at various level of institutional affiliation, from private teaching to university level degree training. Some are speech pathologists. Some are choral conductors, preparação vocal (vocal preparation) specialists, and all of them play either piano or guitar, even though this fact is often concealed behind their role as intérprete. And there is much overlap between people who perform, teach, treat and train. They get together once a month or so, to have discussion groups on a particular vocal topic, or to run workshops aimed at exploring various aspects of the voice. The workshops are generally open to the public. I would say that the very existence of such an association and the 
opportunities to improve singing is in service of - and evidence of - a search for national music of quality. Mariz and I had the following exchange:

Mariz: Vocal[SP] started because of those questions. One thing was that up to this day we don't really... we do have a vocal MPB pedagogy. But it's not like the classical one, and not like the belting one. It's like something that, how do you call a school of singing? Something that is not homogeneous. How do you say that this is MPB, and this too, and this can be taught. Well, it's completely different. Elza Soares and Nara Leão... how could you say that those two are in the same book?

Beausoleil: Do you call them both MPB?

Mariz: Yes! By all means.

By "those questions," Mariz refers to discussion revolving around what is Brazilian popular singing, how to teach it, and how to categorize it in the face of such variety of sounds produced (Personal interview, June 11, 2015). Part of the confusion is based on the fact that MPB is often treated like a genre, rather than a set of canons. When seen as a canon, one can embrace many different styles of singing, without a sense of contradiction. Private voice teachers of popular singing in São Paulo actively seek to understand the popular voice as an entity that is worthy of study in a formalized manner, thereby elevating it to the status of an instrument, and elevating its role in the musical culture, rescuing it from the depths of what is considered to be rubbish music. Beyond escaping the pitfalls of commercialism, these singers honestly want to create high quality vocal work for its own sake, and they put a great deal of emphasis on vocal health. Some of their workshops are focused on somatic vocal work, and they invite guest teachers from abroad to keep themselves abreast of any new vocal philosophy. In August of 2012, I attended a master class held at Canto do Brasil, aimed at improving vocal technique, given by 
classical singer Dominique Moaty, from Paris. And more recently, VocalSP sponsored a visit from vocal guru Jeannie LoVetri, from New York, to share her insights in São Paulo. I, myself, was recruited to give master classes in vocal technique to students at Faculdade Santa Marcelina, Faculdade Cantareira, and UniCamp. In short, I perceive a great thirst on the part of the São Paulo singing community to continue to strive for better understanding of the voice as an instrument in its own right, and to learn from all sources possible.

During my stay in São Paulo in 2015, VocalSP conducted the master class discussed earlier, given by Passos. Passos is a highly regarded musician with an international career that spans almost five decades. She identifies as an intérprete, although she also composes and plays guitar, skills that she downplays in favour of her singing role. It is very telling that she was hired to teach a vocal master class, not a song-writing, or instrumental class. And although she is an accomplished composer, one of the things she insisted upon the most during the workshop was that it is, in her estimation, harder to sing someone else's songs than one's own. She was adamant that to call oneself an intérprete, a singer must be able to "give her own reading" of a song, and that when we sing our own songs, we don't have to do the same internal search that we do when we sing other people's work. In Chapter Four, I will explore in more detail what is considered to be a good voice. For the purposes of this chapter, however, I would like to draw attention to the impact someone like Passos has on the singing community in São Paulo.

Interestingly, out of twenty-five active participants of the workshop, plus perhaps another twenty-five more people in the audience, there was only one male 
active singer and two or three more men attending. And as is typical in MPB ensembles, the house band responsible for the accompaniment was an all-male quartet, playing piano, guitar, double bass and drums. Several times throughout the three evenings of the master class, Passos reminded us that she was not a teacher, but rather, in her words:

Eu estou aqui fazendo pra vocês um trabalho, fazer pra você experiência de vida com a música, com minhas viagens, com esse tempo de estudo que eu tenho. (Public communication, June 23, 2015)

I am here working for you, making a life experience for you with music, with my travels, with that time of study that I have. (Public communication, June 23, 2015)

Her mission was not so much to teach us how to sing Brazilian traditional repertoire, but to impart the values associated with this music. Like many, Passos seeks to identify with this music on a national scale. As discussed in Chapter Two ${ }^{50}$, one of the criteria for participating in her workshop, for instance, was to sing what Passos called "traditional Brazilian music." She was particularly tough on students who were not at a professional level of performance, sending them home to study more. "Tem que estudar" (You need to study) became her refrain. A handful of performers who received her approval, were showered with praise and held up as "intérpretes." A private teacher may have taken into account each student's individual goals, but in this setting, the master class was an opportunity to be in the presence of the master, to receive her feedback, and to learn from an intense performing experience. And from the master's standpoint, it was primordial that as a representative of the Canon, she maintains her credibility. Her praise had much

${ }^{50}$ Please see Chapter Two, page 79. 
more weight in the light of her willingness to send students back to the drawing board. The Canon serves as a fortress against intruders, and it needs to be protected by those on the inside.

VocalSP has held several other workshops and master classes since their inception in 2012, employing both invited guest speakers and teachers, as well as their own internal members' expertise. They touch on many themes, such as somatic voice work, the rock voice, vocal interpretation, history of the "important composers," the masculine voice, and the child's voice (Group interview, June 27, 2015). They actively seek to promote a culture of healthy and sound vocal technique in a variety of styles, which they often divide into "popular" and "erudite."

\section{Conferences}

Finally, occasional conference presentations given by a variety of teachers, by organizations such as diverse as the Order of Psychologists to which Menezes gave a presentation on the history of Brazilian song. In March of 2013, in the context of the Panamérica Canção joint project between USP and Carleton University, Amin presented The Brazilian Way of Singing. Amin describes the process by which popular singing came into being as a result of the invention of the microphone in the 1920s. According to Amin before the microphone, the only ways of projecting the voice was through shouting or by "singing with lots of resonance" by employing classical vocal technique (Amin, 2013). As she says it, the important change brought on by the microphone was that “'Uneducated' singers could finally sing for big audience [sic]." She talks about two branches of Brazilian singing: "legit" singing in 
the European tradition; and "roots" singing following a strong African influence in popular singing. She places bossa nova style singing, as credited to João Gilberto, at the centre of the history of MPB. Table 2, below, resumes Amin's assessment of the changes brought on by bossa nova singing (2013).

\section{Table 2: Brazilian Singing Before and After Bossa Nova}

\begin{tabular}{|l|l|}
\hline Before Bossa Nova & After Bossa Nova \\
\hline "Big voices" & "Small voices" \\
\hline Lowered larynx & Speaking voice configuration \\
\hline More resonance & Less intensity \\
\hline Vibrato & Little or no vibrato \\
\hline $\begin{array}{l}\text { Exaggerated articulation (as in classical } \\
\text { singing) }\end{array}$ & Consonants close to speaking voice \\
\hline $\begin{array}{l}\text { Dramatic lyrics of unrequited or lost } \\
\text { love, }\end{array}$ & Less dramatic lyrics, everyday life \\
\hline $\begin{array}{l}\text { Lots of portamenti } \\
\text { Mixed register }\end{array}$ & $\begin{array}{l}\text { Melodic contour more complex, bigger } \\
\text { leaps, chromaticism, }\end{array}$ \\
\hline Clear voices & $\begin{array}{l}\text { Mixed voice register with chest voice } \\
\text { dominance for women }\end{array}$ \\
\hline $\begin{array}{l}\text { Ranges: high for women, low for men } \\
\text { (no falsetto) }\end{array}$ & "Noisy" voices very well accepted \\
\hline
\end{tabular}

The pre-bossa nova singers that Amin highlights are Vicente Celestino, Isaurinha Garcia and Francisco Alves. Isaurinha Garcia, who had a fifty year career, recorded over three hundred songs, is immortalized in a 2003 play entitled Isaurinha—samba, jazz and bossa nova, was the first "Queen of Rádio Paulista" in 1953 (Carvalho, n.d.), is clearly one of the important, yet often overlooked female singers in histories of MPB. Although her name is mentioned five times in Severiano's well-known history of MPB, it is mostly within lists of singers in particular eras. She merits a sentence of her own as a follower of another female 
singer Aracy de Almeida. Garcia is said to have "made a path of her own" (Severiano $2008,171)$. Amin took the opportunity of the conference presentation to bring this singer to the forefront.

In September 2013, I attended a presentation in São Paulo by renowned lyricist Carlos Rennó51, in which he explained and defended his translations of Cole Porter into Portuguese. The care and conscientious work that went into these versions is remarkable. He explained all the musical considerations that were a part of the song translations, and how much effort he put into finding the right sentiment, as well as the right sound to make the songs work in Portuguese and achieve a high level of quality. The presentation was followed by a short concert of the songs in question by MPB artists Lívia Nestrovski and Fred Ferreira. I find it worthwhile to draw attention to the format of lecture recitals and conferences as a manner of disseminating MPB and a way of contributing to the construction of the canons. These formats for instruction and discussion maintain an air of elevated musicianship, and attract an educated and fairly affluent clientele. To discuss MPB in these contexts provides a legitimating opportunity for popular music, by associating it to the intellectual element.

\section{Conclusion}

Music education reinforces, and responds to, the canons of MPB at all levels. Although other training grounds exist, such as music festivals, I have chosen to focus

${ }^{51}$ Rennó's career was launched by his activities with the Paulista Vanguard in the 1980s, alongside singer-songwriters Tetê Espindola and Arrigo Barnabé. 
on overtly pedagogical contexts. The impact of music festivals on the canons of MPB could very well be a dissertation in itself, particularly within the context of a study on music as labour. However, through the levels studied here, from experiential knowledge and skill acquisition to formalized university education, we can see that there has been an increase in professionalization throughout the history of MPB in general, and of intérpretes in particular, as the central performers of this music. Gracelli observes that since he left his hometown of Vitória twenty-five years ago to move to São Paulo, there are many more, and varied, opportunities to hone one's craft in MPB. He cites an increase in the demand for music schools, workshops, open mike nights, jazz festivals, and performances by experts from abroad (Personal interview, June 11, 2015).

Exploring the relationship between music education and the canons of MPB allows us to observe the multidimensional impact of musical canons. Canons are a powerful mechanism of national identity construction. They also perpetuate value systems that belong to a select group of people who enjoy privileged social status. One of the effects of increased professionalization in MPB is an increase in the force of its canons, as they get passed on to large cohorts at a time, and are reified by institutional curricula. At the same time, canons provide a knowledge base that grows and increases the flow of information, potentially raising the level of quality of the music in question. Conversely, it could be argued that institutionalizing the practice of popular music has the unintended consequence of lowering the bar, by virtue of the fact that students have replaced a certain degree of life experience and musical practice, with a focus on academic achievement. A possible drawback of 
increased professionalization is that university institutions, particularly private ones, have an interest in making financial ends meet and are motivated by profit. This can lead to students being admitted to university level programs who may not otherwise have a chance at a music career, whether for lack of talent or aptitude. Institutional standards are not immune to the adverse effect of financial incentive and commercial interests, which can lead to a decrease in competence and skill. And the professional programs may represent a "short-cut" of sorts, offering students a way in, but lacking in the painstaking personal study that leads to mastery in the "old-fashioned" sense. They have the degree, but they haven't spent the same number of hours applying themselves, listening, forging a technique. The quality that is the hallmark of MPB is then compromised in a "race to the bottom." This is the process that some musicians bemoan as the increase in "rubbish music" that makes it more difficult to disseminate the music of quality that they are proud of naming as Brazilian.

It does not suffice to stop at the assessment that elite classes impose their views on the rest of society by defining the parameters of good taste. The naming of MPB as a Canon can be used to effectively broaden the spectrum of what is to be considered quality, and who is the bearer of that quality. The political and hegemonic nature of canons is such that they thrive when undisclosed. The canons certainly shift over time. Artists vying for position within them, in search of success and immortality, push the envelope of what can be considered MPB. As in the case of someone like Lenine, artists hold a great deal of agency in how the canon shifts and adjusts to changing musical and social values. More and more women are finding a 
place within the MPB Canon by resisting its hegemonic barriers, a task that is formidable, to say the least. The inclusion of more diverse authorities in the canons is challenged by their inherent exclusionary motivation. To borrow a phrase from Citron, "who's in and who's out" is of primordial interest to those on the inside. And even amongst insiders, as is the case between the canons discussed in Chapter Two, some artists are considered to be "more equal than others."

As primary agents of the canons, teachers, who are most often artists themselves, have a vested interest in constructing and perpetuating canons to ensure quality, credibility, status, and national spirit. At the same time, these same artist-teachers are responding to an ever-shifting emphasis on higher learning and intellectualization that makes the canons an essential tool in the preservation of a national music of quality. As we have seen, most music teachers maintain activities under more than one location and employment situation, touching most often on two or more levels of musical training. They may be a professor at a university and still take on private students in their home. They may have students at several small private music schools and still have private students of their own. Or, as is the case for Machado, they may be a university professor and own their own commercial school.

I return to Gracyk's point that breadth of musical taste is proportional to educational level (Gracyk, 2007, 32.). Perhaps the increase in professionalization is advantageous for women, offering a more level playing field with their male colleagues, through increased access to the same mentors and information. Or maybe, professionalization is an effect of a demand by women to receive the 
qualifications necessary to participate in the music field in a safe and respectable manner, one that removes the art form from the streets of the red light district, and puts it in a place of respectability. Perhaps there is hope of broadening the scope of "women's work" in MPB. Unfortunately, these opportunities are not available to everyone equally. Although state university programs are free in Brazil, access to them is highly competitive, with insufficient spaces to meet the demand, and the requirement to pass an entrance exam (H. M. Vianna 1996, 183). Heraldo Marelim Vianna refers a "general educational crisis in Brazil," which impedes access of under-privileged groups to institutions of higher learning, particularly prestigious ones $(1996,187)$. Ironically, students who attended private elementary and secondary schools have a better chance of passing the most prestigious university entrance exams, while students who attended public elementary and secondary schools are more likely to have to pay for a private, often less prestigious, university program, the costs of which can be prohibitive (Faleiros, personal interview, June 23, 2015). The crisis that Heraldo Vianna describes from over twenty years past does not appear to be resolved. 


\section{Chapter Four: São Paulo Voices and MPB canons}

This chapter shines a spotlight on the vocalists of MPB. My purpose is to underscore the role of intérpretes in MPB, to draw attention to their centrality and importance in this music, to their contribution to the quality of the music, as well as to the very national identity this music is aimed at constructing. I will outline the place of the voice in relation to the canons of MPB, and explain some of the factors that hinder vocalists' ascension in the hierarchy of MPB. I will begin by discussing the various terms used to describe vocalists, and the subtle distinctions between them. I will then present this role in relationship to those who hold the keys to the kingdom of authorship in MPB, i.e. the cantautores (singer-songwriters). I will explain the double bind in which female singers find themselves vis-à-vis other musicians in MPB, and highlight their actual contributions to the multiple genres that occupy the MPB space. My goal is to cast the spotlight on the central players - i.e. the singers whose artistic competencies are all too often taken for granted in a musical milieu that rewards subservience to the composers, and where innovation is commended only within very strict rules that are circumscribed by that subservience. Given the gendering of these roles, it becomes evident that the avenues open to women in MPB have been highly curtailed.

While nowadays many more women are penetrating the fields of composition and instrumental playing, it is clear that true equality is still somewhat elusive. All the while, those singers who actually choose the voice as their primary instrument are undermined by the second place the voice occupies behind instrumental playing and composition. Vocal interpretation in MPB is held up by its 
ubiquity, and the connection between MPB and literary arts, and simultaneously held in check by its subordinate position to the composition itself. The arbitrariness of this set of values is made all the more compelling when viewed through the lens of the gendered roles typical of MPB ensembles. Furthermore, the roles occupied by Afro-Brazilian female singers are doubly circumscribed by assumptions of what they must sound like, and the genre of music they must perform (Santhiago 2011).

While the thesis conclusion will provide several musical examples and open the door to further study of vocal signifying, this chapter will discuss who the singers are and how they fit into the canons of MPB. This chapter will illuminate some of the issues facing vocalists and how they position themselves, and are positioned, in relation to the canons of MPB. I will draw attention to the fact that female singers are more than simple mouthpieces for their male auteurs. Quite the contrary, I believe that the art of vocal interpretation, apart and aside from any other musical activity, such as composing and playing an instrument, brings an indispensable element to the music that is generally understated as an actual writing exercise. For better or worse, the voice participates fully in construction of MPB, and its values of Brazilianness and quality that are born in performance, without which the music would have no body or soul. It is through the voice that a national music of quality is made real. To borrow from Amanda Weidman, this is "a process in which certain largely invented speech forms, rather than indexing preexisting social groups, actually bring those groups into being" $(2014,45)$. Two case studies will cap the discussion, to put some of these issues into perspective. 


\section{Intérprete v. cantora - terms for vocalists}

To develop our discussion about vocalists, it is helpful to understand the various terms used to denote a singer in MPB. Words like "intérprete" and "cantora," while often used interchangeably, have important differences in meaning that are only apparent in context. Also, I have found that the pejorative term "canário" (canary) has a secret life in the MPB lexicon, much as it does in North American jazz circles (Beausoleil-Morrison 1999). The difference between "intérprete" and "cantora," or "cantor," is rooted in the specificity of the action it refers to. Both terms can be applied to vocalists of any genre or style. A single person can be both intérprete and cantora, but they are not exactly synonymous. Based on my field research in São Paulo, I have come to understand that the term intérprete refers to the use of mind to decipher and transmit meaning through the voice, while cantor, or cantora, refers to the physical process of opening one's mouth to sing. Both are using the vocal apparatus as sound maker, but the intérprete uses a level of critical and personal engagement beyond the physical and acoustic production the notes. "Intérprete" has to do with reading and delivering meaning, while "cantor(a)" refers to the singer as an embodied producer of sound, without necessarily referencing any signifying gesture.

"Intérprete" refers to the person who uses their voice as a sound maker and as a deliverer of lyrics, but may not necessarily have any training in vocal technique, per se. Depending on the context, the word intérprete does not necessarily preclude other activities such as composition, writing lyrics or playing another instrument, any more than calling someone a guitarist would preclude them from singing. 
However, Mariz confirms that no term exists to denote a singer whose main role in the ensemble is that of lead singer, and who performs exclusively as a vocalist interpreting someone else's compositions. She reckons that "intérprete" is the closest in meaning (Personal e-mail October 28, 2016). It should be noted that all of the intérpretes I met in Brazil have enough piano or guitar skills to accompany their voice students, even if they do not accompany themselves or others on stage. Mariz and Nestrovski would fit this profile. As we discussed in Chapter Three, Passos considers herself an intérprete, although she is also a composer and often accompanies herself on guitar. She generally works with a lyricist. ${ }^{52}$

Cantora, or cantor, refers to someone who sings, without any assumption of doing so exclusively, or to a level one might call virtuosic. Anyone who sings can be called "cantor," while "intérprete" usually refers to a person who sings well. Intérprete is a person who puts his or her own stamp on a song, who transmits musical thought through the voice. This can be done through timbre, texture, inflection, phrasing, and improvisation. I look forward to further study on techniques of vocal signifying in MPB, through the analysis of specific songs. Cantora, or cantor, is neutral from an interpretive perspective and refers specifically to the act of singing. The reason this distinction matters is that singers are judged on both their singing ability and their interpretive skills separately, which permits allowances to be made on one or the other. For instance, Mariz explains that someone like Chico Buarque, who falls squarely into the category of top canonical

\footnotetext{
52 The lyrical content and the role of the lyricist in MPB is a topic large enough to fill a study of its own. Unfortunately, it lies beyond the scope of this dissertation.
} 
MPB composers, can be considered a great interpreter, even though he is not a great singer. She clarifies it this way:

Por exemplo, Chico Buarque - é muito comum se dizer que é o melhor intérprete de suas próprias canções. ... Me parece que o que consideramos um grande cantor envolve virtuosismo vocal ou uma voz muito bonita, ou muito potente... Aqui se aceita que compositores intérpretes não tenham vozes exuberantes. (Personal e-mail, Sept 2, 2016)

For example, Chico Buarque - it is very common to say that he is the best interpreter of his own songs. ... It seems that what we consider a great singer involves vocal virtuosity or a very nice voice, or a very powerful one... Here it is accepted that composerinterpreters do not have exuberant voices. (Personal e-mail Sept 2, 2016)

Mariz further explains that "intérprete" is usually used in a positive light. And I have noted that this is true whether the word is qualified or not. On the other hand, in the context of the Rosa Passos master class, we were all cantoras, with the exception of one single cantor out of twenty-five participants. "Cantora" has no bearing on the quality of the singers, but rather simply that they were singers in this workshop context, whether professional or amateur. However, when Passos applied the term "intérprete" to any of the singers, it was understood as a great compliment.

In short, the words "intérprete" and "cantor(a)" are applied to a broad range of musicians, and their significance is highly contextual. And the meanings are conflated by the fact that MPB is vocal music. Therefore, no matter what other instrument a musician plays, or whether they compose, they also usually sing. Singing, unlike playing another instrument, is a birthright, so the standards of usage vary greatly. 
According to VocalSP, in the singing role, the intérprete receives the highest status, the cantor(a) is second, and the "canário" is definitely at the bottom, representing a class of singers who basically do not have the skills necessary to be considered a musician in today's environment. In today's professional music world, a singer who is musically illiterate and does not have theoretical knowledge, no matter how well she sings, or interprets, is still a target for this pejorative label. This is also the case in North American jazz (Beausoleil-Morrison 1999).

VocalSP discussed the term "canário" and how it applies strictly to female singers. This topic was raised in the context of the respect that is accorded to intérpretes in general. Varying points of view were expressed with a great deal of enthusiasm and the conversation was quite animated. Some members had never actually heard the term "canário" used in their professional dealings. Nevertheless, there was consensus over the fact that it is a pejorative word that is applied specifically to female singers who are considered incompetent. Unfortunately, in many cases, we could simply add a comma here and say "canário" applies specifically to female singers, who are considered incompetent.

I strongly suspect that the way that competency is judged is the issue. I want to ask: against which standard is the competency of singers judged. If a person is hired as an intérprete, she is required to perform the music of the authors, who as we saw in Chapter Two, are typically the composer and lyricist. So composers and lyricists, who are generally male, are often writing for female performing artists. I would like to draw attention to two core values at work in the discrepancy between vocal competence of men and women. First, as encapsulated so well by Mariz's 
example of Buarque interpreting his own songs, composers are not expected to have the same level of vocal virtuosity as non-composer intérpretes, which implies a gendered double-standard in MPB. And second, as in many other areas of life, women are simply required to have a much higher level of competence in order to receive the same recognition as their male counterparts.

\section{The intérprete in a composer-centred practice}

As I observed in Chapter Two, MPB is a composer- and work-centred practice. Composer supremacy is a value that has been inherited through nineteenth-century European classical aesthetics. Musicologist and popular music expert Simon Frith tells us that the popular music realm tends to, in many cases, efface the role of the composer in favour of a performer-based authorship system of recognition (1996). As MPB hovers between the realms of the "erudite" and the popular, its position on authorship is often ambivalent and ambiguous. In other words, there is a tension between the canon of MPB as vocal music, and the canon of MPB as a composercentred practice.

Simon Frith encourages us to understand the popular singing voice on four different levels: as a musical instrument, as a body, as a person and as a character (1996). He points out that aesthetics differ from style to style, that the pop musician as interpreter is more recognized than pop musician as composer. Frith points to the fact that there exist many biographies focused on performers rather than composers (1996). He states: "we hear [popular music] singers as personally expressive," as opposed to classical singers, where vocalist's sound is determined by 
the score and success is measured by the singer's ability to faithfully render the composers intentions $(1996,186)$. In MPB, intérpretes are expected to do both: to create a sense of uniqueness in performance, while maintaining a respectful piety toward the work itself, and the composer's intentions. Those who are perceived to accomplish this balance, such as Elis Regina, are widely revered in their own right, but only to a point. As Menezes states: "Ela era como quase uma compositora" (She was almost like a composer) (Personal interview, June 22, 2017).53

Anthropologist Amanda Weidman accounts for the different registers upon which the voice is studied, from the figurative sense of "having a voice," to the physical aspects of the bodily instrument. She reminds us that Western metaphysics and linguistics provided two important ideas about the voice. Firstly, the voice, as a guarantor of truth and self-presence, expresses the self and identity. Having a voice, in other words, is tantamount to having agency. Secondly, "that the sonic and material aspects of the voice are separable from and subordinate to its referential content or message, an assumption that underlies much of modern linguistic ideology" $(2014,39)$. Feminist philosopher Adriana Cavarero argues that the voice communicates itself first, before communicating the meaning of words (2005). She discusses the sound of the voice as it is tied to unique identity, something that she says has been lost in the search for an intellectualized ideology, which she ascribes to outdated patriarchal principles. She states:

An antimetaphysical strategy, like mine, aiming to valorize an ontology of uniqueness finds in the voice a decisive - indeed, obligatory - resource. ... the aim is to free logos from its visual substance, and to finally mean it as sonorous speech... $(2005,179)$

${ }^{53}$ Please see Chapter Two, page 108. 
She insists that the mother teaches uniqueness to the child, through her bodily connection, and emphasizes teaching as experience, rather than a systematic method. Cavarero's point is to reclaim what she feels has been lost in the history of logos, that which is not visual but auditory. Cavarero criticizes traditional metaphysics, semiotics and structuralism, which in her view associated the body, by way of the voice, to the feminine, and the intellect, through logos, to a masculine domain $(2005,6) \cdot{ }^{54}$ At first glance, the kind of dualistic thinking that she condemns would seem to reflect the relationship between vocal interpreters and composersinger-songwriters in MPB. The value of composition as the zenith of musical activity, and its relationship to male power are not coincidental. The establishment and maintenance of canons serve as a mechanism by which patriarchal thinking can become entrenched in the collective psyche. As discussed in Chapter Two, one of the powers of canons is that even those disadvantaged by them, are often co-opted into keeping them in place.

Social historian Ricardo Santhiago (2011) describes the ways in which "Brazilian black women non-samba singers"' mobility is restricted because they do not conform to the widespread expectations. While some exceptions do manage to make a career, they receive far less attention than Afro-Brazilian samba singers. Santhiago explains the double-bind in which Afro-Brazilian female non-samba singers find themselves. On the one hand, assumptions about racialized musical ability provide an opportunity for them to make a career in music, thanks to the assumption that the samba is "in their bones." On the other hand, those assumptions

${ }^{54}$ Please see Cavarero, cited on page 5 of the Introduction. 
keep them trapped in a specific genre, and leave them out of others, such as bossa nova, which Santhiago qualifies as "that most prestigious genre of Brazilian popular music" $(2011,52)$.

Hidden behind this praise for a supposed gift for the samba, in fact lie subtle ways of compressing the space of Blacks in Brazilian music, which admits Black artists into a narrow range of options for dealing artistically with their own blackness. $(2011,51)$

By the same order of logic, one could argue that women in MPB are constrained in a "compressed" area of specialization as singers. The vocal role is the most accessible one for a woman who wishes to participate in MPB, a door that is often closed to her if her primary instrument is not the voice, or if she favours composition. This is the means by which women are co-opted into their own oppression. The problem is not that women sing, or that they sing well, but that they are limited to the role of intérprete and kept at bay in other musical activities, particularly those that represent the top strata of the musical achievement. Or as Santhiago puts it in the context of Afro-Brazilian non-samba singers: "The problem, nonetheless, is the gap which reproduces, in the musical field, the social stratification that still governs Brazil” $(2011,52)$.

It is widely acknowledged that the domain of the voice, in MPB, is the province of women, and that the men who sing are overwhelmingly, and primarily, composers. In the words of César Braga-Pinto, in his study on "Transgendered Voices in Brazilian Popular Music": "Just as it is rare to find women composers [prior to the 1960s], it was likewise quite uncommon for a man to perform if he did not compose" $(2002,191)$. Uncommon perhaps, but nevertheless noteworthy, as 
evidenced by the different treatment male and female singers receive in histories of MPB.

Jairo Severiano's influential book, Uma historia da música popular brasileira (A history of Brazilian Popular Music), lists several "important composers" from the 1930s and 40s, all of whom are male ([2008] 2013,169). The book then enumerates the "grandes cantores" (great singers) of the same era, beginning with Orlando Silva and other male singers. He follows this up with a list of female singers, which he qualifies as "até mais numerosas" (even more numerous), beginning with Aurora Miranda (sister of her more famous sister Carmen Miranda). Marília Batista also appears in the section on female vocalists, although the author mentions that she "also composes" ([2008] 2013, 170). Batista was formally trained in theory and solfège, was composing by the age of eight and played guitar from age six (Carvalho, n.d.). The order of information provided in Severiano's history is rather telling as to the hierarchy of roles played in MPB. That is, in order of appearance: male composers, "the great" singers, who happen to be male, followed by "female singers," whose composing and instrumental credentials are secondary and whose "greatness" is undetermined.

Menezes shared with me the details of his lecture on the history of Brazilian song, stating that it can be summarized with a joke, which he qualifies as "uma piada muito brasileira" (a very Brazilian joke), as it was told to him by composerperformer Alceu Valença. Before beginning to tell me the joke, Menezes prepares me by saying that in the last fifteen years or so, there has been a type of music called 
"axé" which he says many people call "bunda" (booty) music, because it features

sexually provocative female dancers. Menezes quotes Valença:

A música brasileira começou com Vicente Celestino.... Vicente Celestino é um cantor dos anos dez, dos anos vinte, no Brasil. Ele cantava com o peito. É uma técnica de ópera. Era um cantor de circo, Vicente Celestino. E aí, depois o Chico Alves, é um outro cantor, que depois, nos anos trinta, o Chico Alves cantava com a garganta. E aí, vem o Orlando Silva. E o Orlando Silva cantava com o palato. E aí o Nelson Gonçalves trouxe pra frente da boca. E finalmente João Gilberto trouxe pelo lábio. ... Enfim, esse é uma espécie de percurso da voz brasileira masculina. E a piada consiste em dizer: Depois que veio do peito pra garganta, pro palato, pra a boca, cá desceu pra bunda... (Personal interview, June 22, 2017)

Brazilian music started with Vicente Celestino. ... Vicente Celestino is a singer from the 1910s, from the 1920s, in Brazil. He sang with his chest. It is an opera technique. He was a circus singer, Vicente Celestino. And then, after that Chico Alves, another singer, who in the 1930s, Chico Alves sang with his throat. And then came Orlando Silva. And Orlando Silva sang with his palate. And then Nelson Gonçalves brought it to the front of the mouth. And finally João Gilberto brought it to the lips.... Anyway, that is a kind of survey of the masculine Brazilian voice. And the joke consists of saying: after it went from the chest to the throat, to the palate, to the mouth, here it went down to the ass... (Personal interview, June 22, 2017)

I asked Menezes, if this was a survey of the history of the masculine voice, whether there exists an equivalent history of the feminine voice in Brazil. He answered in the affirmative:

Tem. Bem equivalente. Se você imaginar, é que as cantoras não são tão notórias, entendeu, e são em maior quantidade. Tinha muito mais cantoras do que cantores. Então você vai ter ali, umas cantoras que cantavam ou com peito, ou com a garganta, mas aí surge Carmen Miranda nesse percurso. Essas cantoras que vêm antes de Carmen Miranda, elas não são muito importantes na história, sabe. Não são pessoas que são lembradas como referências. Mas a Carmen Miranda é. Mas a Carmen, ela interrompe esse processo. Esse negócio que é daqui pra cá, pra cá, pra cá. [pointing to chest, head, throat] Ela já vem direto pra cá. [pointing to mouth]. (Personal interview, June 22, 2017) 
There is. Quite equivalent. If you imagine, it is that the female singers are not as notorious, you understand, and there are more of them. There were many more female singers than male singers. So you have there, some female singers who sang from the chest, or from the throat, but then Carmen Miranda appears in the course of this. Those female singers that come before Carmen Miranda, they are not very important in the history, you know. They are not people who are remembered as references. But Carmen Miranda is. But Carmen, she interrupts that process, that business from here to here, to here, to here [pointing to chest, head, throat]. She goes directly to here [pointing to mouth]. (Personal interview, June 22, 2017)

Menezes's friend who was present at the interview, suggested jokingly that Carmen Miranda went straight for the bunda. But Menezes interjected, insisting that Miranda is remembered for her voice, but admits it is unfortunate that she was objectified when she went to the United States and became a film star. Then he launched into an explanation about the importance of the spoken tone in Brazilian song. It is important to note that someone like Menezes, who by his own description takes seriously his responsibility to impart a history, rather than his own tastes, begins his narrative of MPB exclusively with male singers, and has a separate narrative for the ladies, who are more numerous, but less notable. This speaks volumes about challenges women have faced in being recognized within the national musical narrative.

The SESC 55 series of concerts entitled "As cantoras e seus compositores" (The female singers and their composers) also points to a dichotomy between female singers and male composers. Passos was in São Paulo in June 2015 to give the workshop discussed in Chapter Three, as an additional activity to her performance

${ }^{55}$ Please see footnote 21 , page 63. 
in this SESC concert series, in which she paid tribute to a canonical male singersongwriter by the name of Djavan. The series ran five individual concerts, all of which featured a female singer, performing the works of a male composer. In the program notes, we find out that three of these singers are also composers. The series, however, focuses on "MPB classics" by canonical composers, in genres spanning "samba, bossa nova, samba-funk, rock, canções e world music" (samba, bossa nova, samba-funk, rock, songs and world music) (SESC Ipiranga program June/July 2015).

The singers in question are at various levels of their performance careers. Two in particular have entered the MPB canon as intérpretes, namely Leny Andrade, who sang the songs of Ivan Lins and Victor Martins, and Rosa Passos. Despite the fact that Passos has composed over two hundred songs throughout her career, she appears here as a cantora. Andrade and Passos's long careers began during the first and second waves of bossa nova respectively, and are therefore now considered iconic singers, and can fill the concert hall three nights in a row. Both of these singers embrace jazz as a foundational training ground for their music making, although they are adamantly nationalistic in their public discourse and repertoire choices. Once again, the rapprochement between MPB and jazz helps to solidify MPB as a middle-ground music between the popular and the classical. For the three younger singers in the line-up-Giana Viscardi, Roberta Campos and Clara Moreno-who each perform for one night, this series presents an opportunity to be associated not only with the male composers on the marquee, but also with the two 
canonical female singers in the line-up. The series suggests that the gendered roles

in MPB are far from being in line with fully integrated equality of the sexes.

Singer Lu Horta, who also plays guitar and body percussion, describes a

malaise she felt, twenty years ago, when she felt that her skills as a guitar player

were inferior to her peers'. She was even told by at least one student colleague that

she should avoid playing guitar while singing, because it made her "turn fragile".

Horta comments:

Era como se as cantoras e os músicos... como se cantor não fosse músico também, não estudasse harmonia, não estudasse percepção, não soubesse o mesmo conhecimento da linguagem. Que nem os bateristas. Sofrem esse tipo de preconceito também. Os cantores sofrem muito. E tinha muito isso em São Paulo. Então, passei por muitos situações de preconceito assim. Tipo "quem é você para ficar falando como eu arranjo," entendeu? Mas isso é uma coisa que já está bem mais diluída. (Personal interview, May 12, 2016)

It is as if female singers and musicians... as if a singer were not a musician as well, had not studied harmony, had not studied ear training, did not have the same knowledge of the idiom. Nor did the drummers. They suffer this type of prejudice as well. Singers suffer a lot. And there was a lot of this in São Paulo. So I went through many situations of prejudice this way. Like: "who are you to be talking about my arrangement," you understand? But this is something that is now much more diluted. (Personal interview, May 12, 2016)

Vocalist and voice pedagogue Mônica Thiele offers her understanding:

Historicamente, a partir do momento que a mulher se colocar no mercado do trabalho, você tem muito mais intérpretes mulheres, do que homens. Porque os homens que saem cantando, pega de 60 pra cá, são compositores. (Mônica Thiele, Group interview, VocalSP, June 27, 2015)

Historically, from the moment that women placed themselves in the labour market, you have many more women interpreters than men. Because the men who come out to sing, take from 1960 to now, are composers. (Mônica Thiele, Group interview, VocalSP, June 27 2015) 
Horta displays hope, if not evidence, that more and more young people are able to break gender barriers, but as Thiele explains, the roles within the ensemble remain entrenched in gendered categories, with the singers being overwhelmingly female and the rest of the band, and particularly the composers being male.

As noted by VocalSP, more women are choosing to write their own songs because it increases their credibility as qualified musicians. As they explained it, a singer who only sings, is considered less of a musician than one who also plays an instrument and/or composes. Marsola offers: "Acho também que quando a pessoa se dizia intérprete, era menos" (I think also that when a person called themselves an interpreter, they were lesser) (Group interview with Vocal SP, June 27, 2015). Marsola and Thiele mention an exception in someone like Mônica Salmaso, a highly successful MPB singer from São Paulo, who is strictly an intérprete, but they say this has gradually become less common since the 1960s. Horta, Machado, Marsola, and Thiele, all concur that since the 1960s there has been a significant increase in the number of cantautores (Personal and group interviews, June 2015). Another important, and more practical, reason to write one's own songs is that it saves money. The cantautor does not have to pay a singer to perform their work, and the intérprete does not have to pay royalties for songs written by someone else. Mariz nevertheless believes that the real reason is that it is harder to receive recognition as an interpreter than as a composer. This was quite a contentious subject during the group interview with VocalSP, and stimulated a great deal of discussion. One the one hand, some would say that there has been a decline in the respect accorded to the exclusive intérprete, in favour of the cantautor. On the other hand, others find 
that the intérprete is a respectful name for the cantor(a). Mônica Thiele offered: "Intérprete é boa cantora, na verdade" (The interpreter is a good singer, in truth); a statement with which both Mariz and Goulart agreed. My field research would indicate that both sides of the argument are true. More and more, as Goulart pointed out, as music is accessed through the internet, songs are associated with the intérprete as much as, and in some cases more than, with the composer. This aligns with Frith's assessment of authorship in popular music, rather than classical music (1996). In the sphere of mass media, MPB authorship gets projected through the performer and people may forget who the composer is. But this seems to be a different animal than the MPB as music of quality that all of my interlocutors hold dear. While the general public may associate what they hear on the radio, or internet, with singers, fellow musicians may have varying degrees of understanding of what singers actually bring to the table, and still display a degree of protectionist fervour that encourages the Canon of MPB as a work-centred art form. I would submit that the position of the intérprete, as well as being a mediator between the composer and the audience, seems to be a mediator between classes of taste. This is a role that I would say is extremely valuable in the propulsion of a national music of quality that has popular traction.

That said, singers do gain in musical credibility by engaging in composition, a fact that Mariz points out does not always produce the best quality music. It means that an artist may put out mediocre material, and still achieve success by virtue of the fact that it is self-composed, rather than actually being of high quality. Institutions, such as the SESC, will encourage new works, even if the quality is 
lacking (Group interview, VocalSP, June 27, 2015). And a singer who interprets someone else's songs may have a more difficult time earning credibility in the music circuit, regardless of the quality of the sound produced. The result can be a race to the bottom, based on factors that have little to do with music, and more to do with the objective of gaining authorial status, which is politically conferred. We must remember that many singers do not view singing as a consolation prize for not playing another instrument. I would argue that the composer-centred approach minimizes the value of the work of "vocalists-by-vocation." It minimizes the power of performance as a creative act, as a compositional act in its own right. Passos offered this advice to participants of her master class:

Não deixe músicos te engolir. Não deixe nenhum músico te chamar vocês de canário. Esse é uma coisa feia, pejorativa. Muito músico faz isso. Não respeita o cantor intérprete. Então estou pra isso é importante você ter o domínio do ritmo, do andamento, e brincar com os seus músicos. ... Sempre digo isso porque no palco não somos nós só. Mas eles sabem que eu estou aqui na frente. Eles tocam pra mim, eu canto pra eles. ... Mas só eu na frente, então tem que ter esse respeito. Têm que ser músicos que entenda a leitura de vocês. Isso faz a gente crescer, e todo um cresce junto. (Public communication, June 22, 2017)

Don't let the musicians gobble you up. Don't let any musician call you a canary. This is an ugly, pejorative thing. Many musicians do this. They don't respect the singer interpreter. So I am for this: it is important for you to have dominion over rhythm, over tempo, and play with your musicians. ... I always say this because on the stage we are not alone. But they know that I am here in front. They play for me, I sing for them. ... But only I am in front, so they must have this respect. They must be musicians that understand your reading [of the music]. This makes us grow, and everyone grows together. (Public communication, June 22, 2017)

Passos's passion for making "rich" music came through very clearly, and she emphasizes this as the main role of the intérprete in MPB. Having a celebrity such as 
Passos recognize interpretation as valuable was good for some singers to hear, as they found themselves defended in a world that often devalues their work (Group interview, June 27,2015$)$. And to others, it was a clear indication of how hard it is to penetrate the canons of MPB as a composer of new material, or as an interpreter of new material. Passos's gestures were in defence of the quality of the music she values, which may be perceived as threatened in by new music, or emerging artists. Even the quality of the repertoire itself is perhaps at risk. The MPB Canon is at risk of being debunked by new composers, but her primary concern in the quality of the music. Passos stated it clearly: she is a self-appointed defender of Brazilian traditional song.

Eu sempre digo que a música é uma entidade, minha gente. Ela não escolha qualquer um. Quando ela escolha a gente, a gente tem uma responsabilidade com ela. Porque ela é generosa. Ela é infinita. Ela lhe da mil possibilidades. Só depende da gente. É a responsabilidade, o amor, e aqui somos missionários da música. (Public communication, June 22, 2015)

I always say that music is an entity, people. It doesn't choose just anyone. When it chooses us, we have a responsibility to it, because it is generous. It is infinite. It gives you a thousand possibilities. It only depends on us. It is the responsibility, the love, and here we are missionaries of music. (Public communication, June 22, 2015)

\section{“Good voice”}

Most of my interlocutors were in agreement that what they consider to be a "good voice" is something beyond technique that has more to do with interpretation. Uniqueness and expressivity were cited most often as the number one criteria for a good MPB voice. For instance, I asked several singers, all of whom are also voice 
pedagogues, what they consider to be a "good voice." The following is a sampling of

responses:

Padovani: (laughs) Boa pergunta. Uma voz expressiva. Acho que mais do que tudo. Eu faço muitas oficinas para estas pessoas [cantores e cantoras]. É uma oficina de técnica Alexander para o uso da voz, uma oficina pelo corpo, quando você está usando a voz. Então é uma oficina aberta. Pode ir gente que sabe cantar muito, e que sabe cantar pouco. E coisa que eu mais falo pra eles é que você não precisa ter técnica, mas você precisa ter expressão. ... A voz tem que ter expressividade. Eu acho que importa mais isso do que a técnica, ou mesmo o timbre. As vezes a gente de deleita com o timbre de uma voz. Mas ainda assim, mais importante que todo, eu acho é essa expressão que você consegue passar ainda que não tenha letra. (Personal interview, June 29, 2015)

Padovani: (laughs) Good question. An expressive voice. I think that is it more than anything. I do a lot of workshops for these people [singers]. It is a workshop on Alexander technique for the use of the voice, a workshop for the body, when you are using the voice. So it is an open workshop. People can attend who know how a lot about singing, or who know little. And the thing I tell them the most is that you don't have to have technique, but you have to have expression. ... The voice has to have expressivity. I think this is more important than technique, or even timbre. Sometimes people delight in the timbre of a voice. But even so, more important than anything, I think, is this expression that you manage to pass on even when there are no words. (Personal interview, June 29, 2015)

Machado: Bom, isso é uma pergunta bem complexa....Uma boa voz... Uma boa voz pode ser uma voz... Talvez uma voz péssima para o conceito da música erudita, por exemplo, do que é uma boa voz. Uma boa voz é aquela que é capaz de expressar, que é capaz de construir significação. Que é capaz transportar emotividade. Pra mim uma boa voz é isso. É Uma voz que é capaz de tocar emocionalmente. Não é necessariamente uma questão de técnica. A técnica pode estar numa boa voz. Ou seja, numa voz com forte componente emocional, mas pode também não estar. Mais ou menos é assim. Acho que pra ser um grande intérprete, muitas vezes é possível abrir mão da técnica, mas do componente emotivo, nunca. Pode ser que um grande intérprete não tenha uma técnica sofisticada. Mas o que faz um grande intérprete é um gesto. Um gesto interpretativo. É a capacidade de expressar emocionalmente. (Personal interview, June 23, 2015) 
Machado: Well, this is a very complex question. ... A good voice... A good voice can be a voice... that is maybe a bad one for the concept of what erudite music would consider a good voice, for example. A good voice is that which is able to express, that is able to build meaning, that is able to carry emotion. For me, this is a good voice. It is a voice that is able to touch emotionally. It isn't necessarily a question of technique. Technique can be in a good voice, or as it were, in a voice with a strong emotional component, but it can also not be there. It is more or less this way. I think that to be a great intérprete, many times it is possible to give up on technique, but on the emotional component, never. It can be that a great intérprete does not have sophisticated technique. But what makes a great intérprete is a gesture, an interpretive gesture. It is the capacity to express emotionally. (Personal interview, June 23, 2015)

I asked Machado if she would name some of the people she considers to have a good voice. She named several singers that have been mentioned throughout this dissertation. Significantly though, she singled out João Gilberto as "o grande, grande referência" (the major one, a major reference) (Personal interview, June 2015). Nestrovski discusses some of the singers who have influenced her, giving insight on what she considers a good voice to be:

Mas a Elis [Regina] era um pouco mais técnica, já em um sentido, mas eu peguei a Nana [Caymmi] porque eu acho que ela é quase uma entidade nesse sentido. Ela não precisa ser técnica pra ser incrível. Eu acho que as pessoas às vezes confundem um pouco; ser técnico com ser um bom intérprete. Isso é uma visão muito erudita da música.... Eu acho que isso é uma visão que muitos músicos têm da música. Porque a gente aprende a analisar música a partir de premissas europeias de análise, então focadas em harmonia principalmente, $e$ técnica vocal. Tessitura, agilidade, timbre. E pra mim essas questões são super importantes também. Mas eu acho que pra a canção, não são as mais importantes. (Personal interview, July 15, 2015)

But Elis [Regina] was a bit more technical, in a way, but I took Nana [Caymmi] because I think that she is almost an entity in that sense. She doesn't need technique to be incredible. I think that people sometimes confuse, a little bit, being technical with being a good intérprete. That is a very classical vision of music. I think that it is a 
vision that many musicians have of music, because we learn to analyse music from the European analytical premises, therefore focused on harmony, mainly, and vocal technique. Range, agility, timbre. And for me those questions are super important as well. But I think that for song, they are not more important. (Personal interview, July 15, 2015)

In my conversation with VocalSP, the question of what is a good voice

provoked an animated debate. There seemed to be broad consensus that even in the extreme case that a singer had dysphonia ${ }^{56}$ and chose to have a short career, rather than preserve the voice through healthy technique, that this would not preclude them being assessed as having a "good voice." Thiele expressed it this way:

Eu acho que é uma boa voz é uma voz que expressa o que o cantor deseja. Esse é a boa voz. A voz como instrumento. É um instrumento que possibilita o cantor estar na sua a expressão. Eu acho que boa voz não tem relação a boa técnica, ou à perfeição técnica, ou não. ... é uma voz que possibilita a expressão. (Group interview, June 27, 2015)

I think that a good voice is a voice that expresses that which the singer wishes. That is a good voice. A voice as an instrument. It is an instrument that makes it possible for the singer to be in their expression. I think that a good voice does not have any relation to good technique, or to technical perfection, no. I think that when one talks about a good voice in this place, it is a voice that makes expression possible. (Group interview, June 27, 2015)

Thiele impresses upon us that the question of a good voice is entirely subjective. For that reason some of the attendees wonder why we even have to address the point, saying there is no consensus and no need to answer the question. However, when I point out to them that as teachers of voice, they all instruct students in the use of their voices, and that there are inherently values attached to those instructions, they agree that this is the case. As the debate carries on, Mariz

${ }^{56}$ Dysphonia is a defect of the vocal apparatus that causes difficulty in speaking or singing. 
points out that there does exist a "good voice" as it is taught institutionally in university faculties like Santa Marcelina, where she works. And this voice is based on the notion of MPB as a music that symbolizes Brazil. She questions the relationship between what they teach institutionally as being MPB and commercial pop music. She admits it is difficult to reconcile with a curriculum that teaches a "less-than-popular" music that the institution supports as more Brazilian than commercially viable Brazilian pop music. She characterizes this as a double reality that she has to deal with as a pedagogue. What is more "representative" of the Brazilian people, music from the tradition they call MPB, or music that can attract stadiums full of people? She states: "De certa forma isso [MPB] criou uma identidade pra nós" (In a way this [MPB] created an identity for us), and Thiele agrees. Mariz adds:

Mas o currículo da Santa Marcelina de graduação é muito calcado nessa música. Da idade do rádio, até contemporaneidade mas um pouco mais da escola do que foi até o master class da Rosa Passos, né. Então nesse sentido daí a boa voz, é uma voz que consegue dialogar com essa tradição, e que seja confortável pra a pessoa, e que ela consegue se colocar aí por coisas novas, então da leitura pessoal, da história, né. (Group interview, VocalSP, June 27, 2015)

But the undergraduate curriculum at Santa Marcelina is very much founded upon that music, from the radio age until contemporary times, but a bit more like from the school from even the Rosa Passos master class. So in this sense, therefore a good voice is a voice that manages to enter into dialogue with that tradition, and that is comfortable for the person, and that it manages to place itself there by innovation, so the personal reading, of the history, you see.

In not so many words, what Mariz is describing is that a good voice is the one that converses with the canons of MPB. And this point of view was salient in the master class by Passos to which Mariz refers. Passos obstinately reminded us of the 
importance of respecting the music enough to study diction, precise intonation, intervals, rhythmic division; technical values that could be considered in line with Western European classical sensibilities of musical precision as well as African rhythmic complexity. Again, although "racial mixture" has been exposed as a mythical ideal, one that is negated by realities of unequal treatment of racialized groups, cultural mixture still seems to have a great deal of traction when it comes to musical values, and is embedded in the discourse of many MPB practitioners.

Although instrumentalists and composers are "excused" from vocal virtuosity, and even though MPB singing is resolutely "popular" (in the sense of not being classical) in its approach and aesthetic, canto lírico nevertheless remains the reference for singing technique for those who wish to exercise it. Female MPB intérpretes, in particular, tend to be the ones to gravitate to classical singing for deepening their vocal musicianship. MPB singers proudly differentiate themselves from classical singers based on the fact that they sing their national music, as opposed to a genre that is clearly defined by the Canon of Western European classical music. ${ }^{57}$ MPB singers often use classical technique as a way of improving their skills in tuning, diction, etc., helping to distance MPB singing from other pop styles, which tend to be associated with facile Anglo-American pop. This is a contrast to what I have noted about the role of vocals in jazz, which are usually associated with the low-brow, popular, less "serious" side of jazz (BeausoleilMorrison 1999). The voice, in Brazil, seems to be worthy of significant respect, and therefore attention to its physical care and technique are prized in what is

${ }^{57}$ Please see Chapter Two, page 69. 
considered quality music. Goulart brings an important distinction between forming a good voice for an amateur and forming a voice for a person who would like to be professional, or even a celebrity. Goulart shares that she does not teach celebrities or people who aspire to become celebrities. She describes her clientele as "ordinary people," who simply want to sing for their personal development. Her main purpose, as a teacher, is to find out what each student's personal goals are, and help them achieve their own objectives (Group interview, VocalSP, June 27, 2015).

Passos, on the other hand treated all participants of her master class as potential professionals. Specific students' goals were secondary to her stated mission of defending Brazil's music, and indeed her own reputation. That reputation is her place in the Canon, which is no small matter. It bequeaths upon her the power to validate, or not, other singers. She can legitimize someone else's music and their voice, with her approval. When an artist who has successfully entered the Canon validates another artist with public acknowledgment or praise, the effect is to raise the status of the recipient of the kudos. In concrete terms, this can go a long way to establishing the underling artist as a member of the Canon themselves, even if a junior one. This leads to very concrete rewards, such as continued work opportunities, more recognition, and better pay. There is therefore a certain economy in mentorship that actually propels or dismantles careers, as well as perpetuating the Canon itself. As a canonical figure, Passos has credibility. She can come to São Paulo, and tell twenty-five or so participants that most of them should have the decency to recognize that they are singing poorly, and either go home and study more, and by that she means listen and work on the voice, or bow out of the 
business of being a professional singer. And the audience applauds her and adores her.

Essentially, the qualities of a good cantor are different from the qualities of a good intérprete, although there is a great deal of overlap. The criteria for each of them are distinct although they both apply to the singing voice. This discussion has gendered repercussions, in that it shows that if the majority of cantores and exclusive intérpretes are female, and the majority of compositores-intérpretes are male, then we are seeing that the expectation for vocal virtuosity is higher when one is a cantora or exclusively intérprete, than if one also composer-instrumentalist. At the very least, male musicians are usually expected to play an instrument, even if they don't compose. As we have discussed, qualifications of composition and instrumental playing seem to dispense with the necessity of technical vocal study. There are exceptions, of course, such as the late Emilio Santiago, who performed exclusively on vocals, and achieved a very high level of virtuosity. Nestrovski communicates very clearly the delicate balance required of a good intérprete:

Eu acho que bom intérprete ele não só tem que olhar pra essas questões de entender, essas questões de ouvir o que a canção quer dizer, como também conseguir daí a partir disso, se apropriar da canção e tornar ela sua. Eu acho que são essas duas coisas juntas: é conseguir comunicar o que a canção pede, e ao mesmo tempo dar um tom pessoal por aquilo. Quando o intérprete consegue fazer isso, eu acho que ele é um bom intérprete. (Personal interview, July 15, 2015)

I think that a good interpreter not only needs to look after those questions of understanding, those questions of listening to what the song wants to say, but also manages from that point, to appropriate the song and make it their own. I think it is these two things together: it is to manage to communicate what the song demands, and at the same time give a personal tone for that. When the 
intérprete manages to do this, I think that they are a good intérprete. (Personal interview, July 15, 2015)

Nestrovski's discourse suggests a strong work-centred aesthetic, a command of the vocal instrument, and expressive qualities all at once. And though many interlocutors were eager to differentiate MPB vocal technique from classical singing, the expectation of virtuosity is nevertheless present, only in a different form. Passos repeatedly called on singers to study their diction, their intonation, their intervals, their rhythm, as well as, and especially, their interpretation.

\section{Gendered expectations of virtuosity}

There is no single word that designates a singer who is dedicated to the voice as their primary instrument. Mariz suggests that the closest thing is "intérprete" (Personal e-mail, Oct. 28, 2015). The same word can apply to singers who also play another instrument. The greatest difference between the two is that the "singersinger" has greater vocal virtuosity than the "singer-player," or the "singercomposer," or "singer-songwriter." So although it may seem like I am splitting hairs to distinguish between singer-singers and the others, there is a gender correlation that makes the contrast rather important. Singer-singers are overwhelmingly female, and it just so happens there is no word in the vocabulary to name them clearly, manifesting linguistically their containment in the shadows of the "real musicians." And as we have seen, though more and more women are finding their way into the song writing and instrumental realms, along with vocals, they are often discouraged from doing so. Although it is unspoken, it certainly appears that the 
expectation is higher that women can and must sing with better technique than men, but that their writing is assumed to be peripheral to their singing, rather than the other way around. Marsola recounts, for instance, that she is primarily a guitar player. When she was the sole female playing in a band at age seventeen, her band mates assumed she was not able to play as loudly as they could, if she were to play at all. As she puts it, they thought she was "a fake" (Group interview, VocalSP, June 2015).

Passos's commitment and subservience to music, and her staunch defence of quality interpretation, point to the power of the canons, which for better or worse were built up as a masculine structure of composition and instrumental playing, with female interpretation. When an audience member asked what she thought about female singers changing or maintaining masculine pronouns in a song, Passos replied that the pronouns should be kept as they were originally written. She justified her answer this way: "Por que no fundo do fundo, os grandes compositores são masculinos, e são femininas ao mesmo tempo. Chico tem uma mulher por dentro. Ary Barroso, Caymmi..." (Because in the deepest depth, the great composers are masculine, and are feminine at the same time. Chico has a woman inside, Ary Barroso, Caymmi...) (Public communication, June 23, 2015). The implication is that women are mainly singers, that they must perform to a high vocal standard, and that they should stay out of the way of composing because this activity belongs to men. Conversely, though most men in MPB also play another instrument, or compose, the few men who are strictly singers in MPB, do so by choice, and are considered notable in their style. Their names are remembered. Emilio Santiago was known for 
his impeccable baritone voice. Orlando Silva, Francisco Alves, stand out as defining the history of MPB singers. On the other hand, competency at the guitar or piano is routinely hidden from view in the public personae of many a female intérprete.

The gendered division of labour has repercussions in terms of the interpretive possibilities in MPB. In the book Lusosex, César Braga-Pinto's chapter outlines the complexities of mainly subaltern sexualities, as they are expressed in the voices of MPB. The author discusses first the misogynistic lyrics of composer Noel Rosa, and how a female singer has appropriated them in such a way as to subvert their original meaning. Braga-Pinto discusses gendered pronouns in Portuguese lyrics and the various identities that surface when a singer chooses to either retain a pronoun as written by a composer of the opposite sex, or to change it to suit the gender identity of the performer. He notes that until the 1960s, it was common practice to adapt the pronouns to suit the gender of the singer, but that after that period, multiple approaches emerge.

The author discusses transgendered voices and their relation to the personal identity of several artists. He pays special attention to a few indisputably canonical artists, including Chico Buarque, Gilberto Gil, and Caetano Veloso. He also discusses intérpretes Gal Costa, Ney Matogrosso, and Cauba. Braga-Pinto talks about the ambiguous sexuality Caetano Veloso presents in his public persona and his lyrics. Conversely, Chico Buarque can write from a woman's point of view and still not have his heterosexuality questioned. Gilberto Gil rarely performs from the female perspective, and is more involved in contestation on the basis of racialization 
(Braga-Pinto 2002, 194). With respect to subjective positioning of the singer, Braga-

Pinto offers this explanation:

This rigid division between male composers, on the one hand, and female performers (intérpretes, in Portuguese), on the other, has contributed to the development of new, ambivalent forms of discourse, at times skilfully manipulated by both composers and performers. Until the 1960s, when (male) composers wrote lyrics specifically for women to sing, these women seemed to be expressing their own female subjectivities. But then more and more women began to retain the genders found in the original lyrics when they performed songs in which the composers either referred to themselves in the masculine, or else declared their love for a woman. These songs could thus be understood as though a woman were performing a male role, but also as the expression of lesbian love. $(2002,191)$

Braga-Pinto reminds us of the fact that these trends have shifted over time and are far from fixed or absolute. He also draws attention to the many "authors" involved in constructing the narrative: "The meanings produced in the slippage between the performer's gender (or sexuality) and those of the poetic voices they perform depend on the context defined not only by the artist, but also by the media and the public" $(2002,193)$. He notes: "Chico Buarque is one of the composers who has most often written songs for female singers to perform, and subsequently recorded them, while always retaining the feminine 'I,' his heterosexual image is seldom questioned" $(2002,193)$. The impression I formed during my field research was that, more often than not, when a Brazilian singer retains a pronoun that would appear to be more suitable to the opposite sex, this is done out of respect for the Canon, rather than an expression of homosexual love. 58

${ }^{58}$ This area of research would benefit greatly from further study. 
It could be said that women have a place in MPB as singers partially because they do it better. Markers of a "good singing voice," that is, clear intonation, pleasant timbre and ease with chromaticism, are less frequently found in male singers than they are in women. This could be a function of the traditional social connection between femininity and verbal communication skills. It could also be a social response to a physiological reality that boys undergo a much more dramatic vocal shift in adolescence than girls do. Mariz and Thiele were in agreement with Marsola when she describes her experience with child singers. She elaborates that by the age of nine or ten, most of the boys she has taught have developed an aversion to singing, whether is it because they associate it with femininity, or because they begin to experience discomfort in using a changing voice in a singing capacity. They simply turn to other instruments and stop singing (Group interview, Vocal SP, June 27, 2015). Beth Amin, who works with several choirs, pointed out that it is harder to get men to sing in tune than women. A full scientific study could be conducted to find out why this is the case, but the gender statistics from choir members from the Coral USP festival, the student ratio at Santa Marcelina's vocal program and Rosa Passos's workshop, the master classes I myself gave at Santa Marcelina, Cantareira, and UniCamp, the SESC vocal series line-up, programming from smaller bar venues, all point to a disproportionate number of female singers.

I spent several days at Santa Marcelina, where Mariz and Nestrovski were both teaching. I observed private lessons given by Mariz in both "canto lírico" (classical singing) and what she refers to as MPB singing. I also had the opportunity to observe the final exams for some of the MPB students, who were mostly in lower 
years of study. The male students were much fewer, and vocally much weaker than the female students in terms of accuracy of pitch and vocal control. I am not suggesting this to be a biological given. Quite the contrary, I am convinced that the social roles that have been assigned have led to an imbalance in the quality of vocal production that encourages vocalization as a feminine activity, and composition and instrumental playing as masculine activities. The change of voice in teenage years is one that can be managed with proper vocal care and guidance, but this is harder to achieve in an environment that is socially loaded with gendered stereotypes. It is important to add here, that I do not believe for a moment that this is unique to Brazil, but that this study has helped me to understand the social context in which this phenomenon may occur. ${ }^{59} \mathrm{~A}$ brief exchange during my group interview with VocalSP suggests that the roles in the band are still very gendered.

\section{Mariz: Numa banda é instrumentistas homens e cantora} mulher. Marsola: É normal.

Goulart: É. (Group interview with Vocal SP, June 27, 2015)

Mariz: In a band it is men instrumentalists and a woman singer.

Marsola: It is normal.

Goulart: It is. (Group interview with Vocal SP, June 27, 2015)

Post discusses the musical roles of women in many cultures all over the world, emphasizing that women have traditionally been relegated to private spheres of music making. Even when women enter the public sphere, their roles are circumscribed by the expectations and standards set by men, and they are often

${ }^{59}$ I look forward to applying some of these problematic questions to other cultural contexts, including my own native Québec. 
restricted to subservient roles vis-à-vis their male counterparts. She notes Linda Dahl's work on women in jazz that shows how women were rarely seen as true peers to male musicians, even when they played instruments in the public sphere (Post, 1994, 45, 47).

Post finds that the voice has traditionally been the most common musical avenue open to women all around the world, largely because it leaves hands free, allowing women to tend to domestic chores. And when women play musical instruments, they tend towards instruments that conform to sexual stereotyping $(1994,40)$. European traditions of femininity dictated that women should not have to alter their face to play and instrument. Post also explains that women's repertoire is largely determined by the standards set by men, whether they be the decision makers, composers or audience members.

\section{Case study 1: Mônica Salmaso}

A discussion I had with Menezes regarding singer Mônica Salmaso illustrates the difficulties in penetrating the structure of the existing MPB canons. Salmaso is currently a top profile São Paulo MPB singer, who performed in Gatineau, Canada in September 2013. On that occasion, she was introduced by the Brazilian ambassador as a young singer of major importance in Brazil. Menezes, however had a different take on Salmaso, reflecting a kind of ambivalent narrative that often accompanies new female talent. My intention in telling this story is not to incriminate one individual, but rather to illustrate a much larger social phenomenon. When I asked 
him why he did not consider Salmaso one of the important singers of Brazil, his

answer leaned heavily on the canon of classical German classical composers.

Boa pergunta. Eu acho que é assim.... O Bach, ele conseguiu fazer a síntese de tudo o que era possível ser feito com a música da época dele. Na época dele, estava descobrindo o temperamento, descobrindo os instrumentos, saindo da polifonia, pra harmonia. Aí o Bach pega tudo isso. Este modalismo pra o sistema temperado, o cravo para piano. Tudo isso está acontecendo. Tem 120 caras na Europa compondo, mais ou menos. Bach faz a síntese de tudo que era possível na caneta. Só que aquela época passa, ele não faz a síntese da próxima época, porque ele morreu. Aí quando vem a próxima época, as pessoas falam: "Isso aqui é muito bom. Mas tem algumas coisas, né, essa época que é isso aqui, não desrespeito, a gente tem que inventar umas coisas que não foram ditas, mais que precisam ser ditas ainda." Aí o Mozart, ele vai, e desenvolve, aí, e também morreu. Aí o Beethoven, e explora. Só que chega uma hora que bate na parede. Depois do dodecafonismo, o barulismo, e aí pra onde a gente vai depois disso? A gente tem que mudar de arte! Então a questão já não é mas progredir. A questão tem que ser outra. Não é só dar pra frente. Descobrir tudo, descobrir, descobrir, ... Na música popular é parecido. ... A Mônica Salmaso está em outra época, ela não está na época que está Elis. Não está mais. O mundo mudou. O Brasil mudou. E ela não faz nada que seja diferente do que já foi feito. Ela faz muito bem. Ela canta muito lindo. Ela é afinada. Ela parece um instrumento. As coisas mais lindas que ouvi da Mônica foi quando ela se colocou como se fosse um instrumento da orquestra. Não é uma cantora solista. Ela é mais um instrumento. (Personal interview, June 22, 2015)

Good question. I think it is like this. Bach managed to synthesize all of the music that was possible to make in his era. In his era, he was discovering equal temperament ${ }^{60}$, discovering instruments, coming out of polyphony and into harmony. Bach takes all of this, from modal music to the tempered system, from the harpsichord to the piano. All this is happening. There are 120 guys composing in Europe, more or less. Bach makes the synthesis of everything that was possible with the pen. Only that the era passed, and he did not synthesize the next era, because he died. Then when comes the next era, people say: "This here is very good. But there are some things, eh, in this period, no disrespect, but people need to invent things, that have not been said, but that still need to be said." So Mozart, he goes and develops, and also dies. Then Beethoven explores. Only that at one point he comes up against a wall. After that twelve-tone

${ }^{60}$ Equal temperament is the division of the octave into even intervals. 
music, noise music, and then where do we go after this? We have to change arts! So the question is no longer to progress. It must be another question. It isn't only going forward, discovering, discovering, discovering... In popular music it is the same.... Mônica Salmaso is not in this era. She is not in Elis [Regina]'s era. It is no longer. The world has changed. Brazil has changed. And she doesn't do anything different from what has been done before. She does it very well. She is very well tuned. She seems like an instrument. The nicest things I've heard from Mônica were when she places herself as if she were an instrument in the orchestra. She is not a solo singer. She is more of an instrument. (Personal interview, June 22, 2015)

Menezes's description is a perfect articulation of an established Canon that is closed to newcomers. Singing in a non-traditional way is not enough to guarantee a singer passage into the Canon, however well she does it. And yet, by Menezes's own definition, innovation is one of the core values associated with mastery and canonical status. While singing instrumentally is not unique, not many other singers in the history of MPB have sung instrumentally as Salmaso and Padovani do.

Salmaso describes her initiation to instrumental singing in this way:

Em 1998 eu fui convidada para fazer uma participação em um show de um grupo chamado Orquestra Popular de Câmara - era um grupo de música instrumental. Uma participação fazendo vocalises. Eu adorei! E acabei ficando no grupo por alguns anos. Gravamos dois CDs e fizemos muitos shows. Foi uma experiência muito importante pra mim porque o papel da voz era diferente da função de líder, que acontece na canção. Em muitos arranjos, a voz está fazendo base para outro instrumento solar. Isso é uma lição para cantores. Eu aprendi a escutar mais e melhor os arranjos e as funções de cada instrumento dentro deles. Isso alterou, inclusive, a minha forma de cantar as canções. (Personal e-mail, April 10, 2017)

In 1998, I was invited to participate in a show with the group called Orquestra Popular de Câmara [Popular Chamber Orchestra] - it was an instrumental group. A feature performance doing vocalises ${ }^{61}$. I loved it! And I ended up staying with the group for some years. We recorded two CDs and did many shows. It was a

${ }^{61}$ Vocalises are wordless vocal passages. 
very important experience for me because the role of the voice was different from the function of leader, which happens in song. In many arrangements, the voice is support for another solo instrument. This is a lesson for singers. I learned to listen more and better, to the arrangements and the function of each instrument with them. This even altered my way of singing songs. (Personal email, April 10, 2017)

From this description we can discern a very high level of care, concern for quality, and for a high degree of vocal musicianship. Unlike the practice of using back-up vocals, where there is usually a chorus of singers using a combination of words and syllables, but are meant to accompany the lead singer's melodic line, Salmaso's instrumental singing actually consists of an independent line in the music, equivalent to the other instruments. That said, she explains that improvisation has never been her modus operandi. She states:

Sempre acho que a escolha feita pelo compositor é melhor do que qualquer alteração. Com isso, meu trabalho sempre foi fundado no canto de canções, na maioria quase absoluta, brasileiras. (Personal e-mail, April 10, 2017)

I always find that the choice made by the composer is better than any alteration. With this, my work has always been founded on singing Brazilian songs almost exclusively. (Personal e-mail, April 10, 2017).

While a singer must establish herself as an innovator in order to ascertain a place in the Canon, she also must not, as Menezes puts it, "pass in front of the music." 62 I find it surprising, and difficult to understand, by what criteria Menezes can claim that Salmaso does not belong in a canonical sphere of artists. His words speak highly of her instrumental singing, but he stops short of praising this as innovation. Even though in doing so, Salmaso actually fulfills the canon of MPB as a

${ }^{62}$ Please see Chapter Two, page 108. 
work-centred practice, by never putting herself before the music. Usually, when a vocalist is singing lead, as the term suggests, the voice is supposed to be more forward in the mix than the other instruments, so that one can hear the melody in the foreground of the musical texture. When Salmaso sings instrumentally, that is, without words, she blends into the texture in such a way that the voice is no more audible than the other instruments, and in fact errs on the side of being quieter. I heard her do this live with the group Vento em madeira, in São Paulo (June 2015) and was conscious of not easily distinguishing her voice within the overall texture among the other instruments. When she sings the lead part in the ensemble, particularly with lyrical content, it is an entirely different balance, where she allows the voice to be more forward in the blend.

Salmaso has won multiple awards since her first cd was released in 1995, which suggests that someone believes she deserves a place in the Canon. She already has ten albums to her name and two DVDs. The ambivalence of the collective commentary about Salmaso's singing indicates how contested a field MPB is, and how fickle opinions about singing can be. It also shows that no Canon is universal, and that opinions will differ as to who is included. Although Salmaso is extremely well-known and has a busy, full-time performance schedule, including international touring, will she endure as an important figure in the MPB Canon? Will singers, now or in the future, emulate her style? Her impact may be felt in the uniqueness of her timbre, which despite using the typical vocal technique that emerged with the bossa nova tradition, has a particular texture that is her signature sound and has earned her numerous accolades and a solid fan base, as well as a 
healthy dose of detractors who find her sound intolerable in its technical perfection. Her voice has a slightly airy quality, particularly in the low registers and an impressive clarity of pitch. Her voice is widely acknowledged as bearing the markings of a honed instrument. That is, she sings in fine tuning and has a respectably broad and unified vocal range. Since she does not improvise, and her sound is almost pristine in pitch accuracy and control, I suspect that her sound may be perceived to be at odds with the top criteria upon which there seems to be broad consensus, that is, expressivity. I cannot help but wonder if her detractors would describe her differently if she were a man. Would she be expected to be as "expressive" and "touching"? Or are these qualities that are simply associated with femininity? If innovation belongs to masculine artists, and expressivity to female ones, then Salmaso is doomed to be locked out of the Canon. Disrupting expectations is a double-edged sword. For some artists, it is a way to gain the respect of the public and other musicians, to fulfill the criteria of originality, or to get the right people listening. For others, it seems to erect roadblocks and attract criticism.

Menezes made a point of telling me that he is not speaking from his own personal biases when he tells me who the important artists are in MPB history, and I believe him. What he was relaying to me was in effect the MPB Canon and its rules as they have been passed down to him. And whether or not his narrative is factually and historically correct is important, but not as important to the current study as the fact that this is the narrative he is sharing through his teaching. His version of MPB history has the impact of a set of canons on those who receive it, and he is positioned as a canon builder. I must point out that the trajectory of MPB that he 
cites is likely strongly reinforced by the hegemonic power of the Canon, which has unfortunately been "written" in such a way as to underplay the role of both women and singers. As noted earlier, canons depend on their own erasure to exist. But they effectively constrict artists who seek to produce new music that is authentic in a personal and artistic sense, whether that is through innovation or faithfulness to a national style. Padovani and Amin, independently talked about how hard it is to create a space for new artists, or unknown artists. They both said: "Não tem espaço!" (There is no space!). The importance of this expression is two-fold. Both women used this expression in reference to the fact that MPB artists have a hard time gaining traction in a market that favours commercial pop music. And on another level, they also feel that the "bigger named MPB artists" tend to get continued attention, in the form of performance opportunities, particularly at desirable venues like the SESC theatres, while emerging artists have a harder and harder time getting their calls answered by presenters. The established Canon leaves no space. Canons act as a protective barrier, to keep insiders from losing their dominant position, which is a work issue ${ }^{63}$. It is about protecting ones job in an industry that guarantees no income or survival. And keeping women out of the Canon, or at least, in their place, is a very common narrative. This narrative does not only belong to singing, or to music, or to MPB, or to Brazil in general. The very same phenomenon is apparent in North American jazz (Beausoleil-Morrison 1999).

As was explained by several consultants quoted above, the element that makes an artist stand out is often the immeasurable quality of expressivity, and

${ }^{63}$ Musical labour has made itself apparent throughout this research and presents itself as an obvious continuation to the current research. 
offering a personal and unique performance. Elis Regina was known for her "noholds-barred" approach to emotionality in her singing, which more than made up for her musical illiteracy. Despite her association with bossa nova era composers such as Antonio Carlos Jobim, her singing was full-throated, and did not follow the bossa nova standard of understated vocals in the manner of João Gilberto, for instance. Regina nevertheless became a standard in her own right, with arguably the largest following of any female singer in the history of MPB. Nestrovski, a current up-and-coming vocalist, said Elis Regina was her greatest influence.

Imitei muito Elis Regina. Por isso eu acho que ela me influenciou, porque eu soava, na faculdade, uma cópia jovem da Elis Regina. A Regina Machado falava: "Deixa a falecida enterrada. Deixa em terra a falecida... Deixe ela lá. Porque de fato era a minha grande referência de canção brasileira. (Personal interview, July 15, 2015)

I imitated Elis Regina a lot. That is why I think she influenced me, because I sounded, in university, like a young copy of Elis Regina. Regina Machado would say: "Leave the dead woman buried. Leave the dead woman in the ground... Leave her there." Because in fact she was my great reference in Brazilian song. (Personal interview, July 15, 2015)

Nestrovski has gone on to develop her own style of singing, based in part on a good deal of influence from the Vanguarda Paulista generation.

What are the limits of what is permissible in the interpretation of Brazilian song? According to many of the MPB singers I observed, it is desirable to improvise the phrasing of a song, which, in effect, means that the singer is tinkering with the rhythm of the melody. An intérprete also is allowed to sing other chord tones and improvise on the melody itself, so long as she is not rewriting the entire song, and that this is done tastefully, with respect to the composition. Passos received this training from the jazz idiom, which she insists aspiring and professional singers 
alike must listen to. She is very adamant that although she has learned her craft through classic American jazz singers, including Billie Holiday, Sarah Vaughan, Carmen McRae, Nina Simone, Nancy Wilson, Ella Fitzgerald, what she is doing is not trying to be an American singer, nor to imitate their way of singing. She basically has learned from the jazz singers an approach to singing, which allows for interpretive moves, such as the phrasing described above. She then applies this approach to Brazilian song. She specifies that what she is doing is "Brazilian song," not "Brazilian popular song." The construction of national identity is at the core of her practice. She also advocates that singers listen to instrumental music, particularly by North American pianists, such as Oscar Peterson. She went to great pains to make the point that a singer must spend a great deal of time studying tuning, dynamics, rhythm, intervals, interpretation, and that this learning could be done essentially through listening, listening, listening! She adamantly argued that this training is necessary. Being from a senior generation of singers, one that had no access to formalized vocal training, she rose through the ranks by listening to others' albums, and also on the job. As she pointed out, no one told her how to study, or who to study. She figured this all out the hard way. It is hardly surprising that Passos feels personally responsible for maintaining a tradition she worked so hard to enter.

This same Canon holds up Afro-Brazilianness as a marker of authenticity, but only to the point where it supports Euro-centric musical values. As Citron reminds us: "because the values encoded in canons have become entrenched over time, their prescriptive and normative powers become ever greater. We begin to see canons as representatives of universal, unchanging values" (cited in Karppinen 2016, 135). 
Passos compared two Afro-Brazilian artists, Martinho da Vila and Paulinho da Viola who are both sambistas from Rio de Janeiro. She said she prefers Paulinho da Viola because he is "more authentic" and "more universal" at the same time (Public communication, June 2015). The universality she refers to is that Paulinho da Viola has a soft voice in a style more compatible with bossa nova than with samba. Passos's bent toward bossa nova is clear from her singing style. On the one hand, bossa nova's aesthetics, which have come to dominate MPB, could be described as bearing the markings of Euro-centrism, and has been viewed as a "whitening" of Brazil's "true" national music — the samba. On the other hand, samba, which in some forms and by some artists is allowed as MPB, is still associated with Africaneity and lower-class music. Ethnomusicologist Ronald Radano states:

Black popular music's qualities of distinctiveness (what we now call authenticity) were attributed to a unique, racial character-to natural rhythm, to hot blood, to a proclivity to dance and sing, to emotional qualities of sympathy and soul-all, tellingly attributions of the black body. Such somatic-sensual orientations, grounded in the common sense of nineteenth-century Western racism that imagined black soundworlds as an unobtainable, supra-economic excess, would drive public fascination with the new generative machine of black difference making. $(2012,312)$

Passos's characterization of da Viola's more "universal" style points to the hegemonic position of Euro-centric musical aesthetics. Just as the canon of MPB as composer-centred practice is grounded in a nineteenth-century European aesthetic, so does the MPB Canon reside, and conceal itself, in a value of universality. Women, and Afro-Brazilians are often co-opted into their own subjugation by a Canon that is ostensibly a canon of quality, while the definition and barometer of that quality tends to favour a canon of Euro-Brazilian men's music. In other words, the Canon 
acts as a self-perpetuating force to protect those within and maintain the status quo. Women gain entry to the canons through vocal interpretation, a role that is assigned to them more readily than any other, and must contend with the disadvantage that this is of lesser status than composing, and as Santhiago shows, Afro-Brazilian women enter the canon via samba (2011).

\section{Case study 2: Lu Horta}

Horta recounts that in her training period at the UniCamp, one of the things she found difficult was that the course was dominated by instrumental improvisation, and that she, as a singer of Brazilian music, felt she could not fit in because Brazilian popular song wasn't about improvisation (Personal interview, May 12, 2016). That said, there are signs that this situation is changing, thanks in part to the pedagogical landscape that allows traditionally disadvantaged groups to receive the training necessary to enter into the MPB fold. Lu Horta was on the cusp of the phenomenon of university studies in popular music in Brazil. When she entered UniCamp in 1989, she didn't know that the popular music program existed, as it had just been inaugurated that year. And since she had not prepared her vestibular (entrance) 64 exam in music in time, she entered in the department of letters. She spent her first year attending music classes with special permission from professors, and preparing to write her vestibular aptitude exam in popular music. She then entered the program in 1990. She already sang in bars before university, and gave lessons in

\footnotetext{
${ }^{64}$ The vestibular is an entrance exam, given over the course of three days, which includes testing in aptitude, ear training and performance.
} 
ear training. She nevertheless says that her professional life as a musician took hold while she was in the university program. She made many contacts there, including her future husband and co-worker, drummer Marcelo Effori. She was in the same class as guitarist Gracelli. Lu describes her time in the popular music program as "uma fase muito difícil como intérprete, por que eu entrei como cantora" (a very difficult phase as an intérprete, because I entered as a singer." (Personal interview, May 12, 2016). She attributes the difficulty to several converging factors; namely, that her instrumental skills on guitar were not as strong as other students', that there were many more men than women in the program, that the environment was highly competitive, and that the program was focussed on jazz and improvisation at the time, and she was approaching it from an "MPB or música brasileira" standpoint. And though she always knew that her first instrument was the voice, having been in choirs and paid for her voice lessons out of her babysitting money, she admits that she had mixed feelings about having to choose between applying as a singer or as an instrumentalist. In the end, she decided that her chances of entering the program were better as a vocalist than as a guitar player.

Horta's voice lessons at UniCamp were with Luciana Souza, a São Paulo native singer who is now living in the United States. Horta specifies that the voice classes were collective, and that there were no individual voice lessons within the program. She describes the group voice classes with Souza as centered on interpretation and on the "musical language" rather than on voice technique. What she thirsted for was a way to understand the vocal instrument from a technical standpoint. This opening was given to her when her choir director suggested a 
teacher of bel canto (classical) singing. Horta credits her subsequent training in canto lírico for her better understanding of the voice, which was satisfying to her.

E eu acho que muitas cantoras de São Paulo, ou da minha geração, tiveram esse mesmo esforço, de fazer essa passagem, desse processo de consciência vocal pro repertório brasileiro. Porque tem uma outra coisa que acontece no repertório brasileiro que é a emissão mais mista. (Personal interview, May 12, 2016)

I think that many singers of São Paulo, or of my generation, had this same effort, of making this transition, this process of vocal consciousness to the Brazilian repertoire. Because there is something else that occurs in the Brazilian repertoire that is the more mixed [vocal] emission ${ }^{65}$. (Personal interview, May 12, 2016)

In this example of Luciana Horta, we see how in MPB singing, the two worlds of classical and popular singing converge, supporting the idea of MPB as a music that occupies the middle ground between the "erudite" and the popular. In order to achieve the accuracy required to perform the typically chromatic and complex melodic lines in MPB songs, singers must gain fluency in the technical aspects of vocal production that are most forthcoming in classical singing. Horta's comments reflect the broad interest I detected in São Paulo with regard to vocal technique, and its importance in MPB. Although the consensus among my interlocutors seems to be that technique is not a necessary marker of a "good" voice in popular singing, many vocalists in São Paulo spend a good deal of time and attention on vocal health and management. The existence of a strong vocal professional association such as VocalSP also attests to the significance of the voice as a musical discipline worthy of recognition and practice. As the program at UniCamp demonstrates, the main focus of popular singing has historically been on interpretation, purposely distancing it

${ }^{65}$ Mixed vocal emission indicates the use of both chest and head resonances simultaneously. 
from the classical idiom. Perhaps one of the reasons that bossa nova singing was so revolutionary, and why it became the dominant sound of MPB, is that it combined aspects from both classical and popular singing, creating a third and middle category that married aesthetics of quality with accessibility.

\section{Conclusion}

This chapter has taken a hard look at MPB canons from the perspective of the central players, i.e. the singers. This has revealed the heavily gendered role that women have occupied thus far in MPB, and some of the ways in which women are co-opted into maintaining the very notions that keep their role circumscribed. There are no roles that are not open to men in MPB. They may be composers, lyricists, instrumentalists, singers, or all of the above. It truly does appear that women are siloed into the vocal role by the strength and hegemony of MPB canons. In theory, women have the right to practice whatever musical instrument they choose, but in practice, it would appear that women have so far been discouraged from competing for greatness in domains other than singing, save for a few rare exceptions. Furthermore when the voice is a woman's instrument of choice, that choice is relegated to an inferior musical status.

Women have developed several different strategies to elevate the respectability of singing. Artists who achieve canonical recognition passionately protect their hard earned status by clinging to quality as a primary motivating factor. Associations, such as VocalSP create a forum for increasing the level of understanding of the voice as an instrument, contributing to the overall quality of 
vocal health and pedagogy, and by extension to MPB as a whole. Through pedagogy, singers convey a sense of responsibility to national tradition, which includes genuine concern for vocal musicianship. These strategies may at first appear to reinforce the MPB canons as they already exist. I would suggest that carving out a place of respectability within the Canon may be the first step in actually redefining the canons of MPB to reflect and integrate more progressive values into the national narrative. Bohlman asserts:

At the end of the twentieth century, there were predictions that music would lose the functions of nationalism because its movement across national borders would erase those borders. The predictions that framed the past century, however, have not come to pass. $(2012,35)$

It has been my goal, with this chapter, to explore the contexts in which canons endure, while at the same time examining how artists can work within them to develop their own voice. Canons may "disappear" into collective imaginations and become hegemonic, but they do not appear to be on a path of extinction. 


\section{Conclusion}

This study has focused on the female artists of MPB, in order to reveal several complexities in the construction of a Brazilian Canon of national popular music. In a culture that values its popular music as a "window" into its soul and identity, it is perhaps not surprising that establishing, and maintaining, "music of quality" should be of particular importance. A focus on the lead singers gives a perspective that is often overlooked, and underrepresented in the literature on MPB.

In Chapter One, I pursued the question of musical nationalization, that is, the process by which musics become constructed as national in scope and representation, as opposed to regional, or local, or international. In the broader context of Latin America, the particular place that popular music holds in Brazil comes into focus. More than many other national musics in Latin America, MPB serves as a site, and a vehicle, for national pride that transcends other areas where national pride is hurting, like health and sanitation, and sports, and politics. An international fetish for Brazilian music helps to secure a sense of belonging on the world stage, even when the zica virus, an olympic soccer loss, and political chaos reign. MPB is one of the ways in which Brazilians can prove that "tem vida inteligente aqui" (there is intelligent life here) (Carlos Rennó, Public communication, September 12, 2012)66.

${ }^{66}$ Carlos Rennó made this statement in the context of a concert-lecture at Casa Guilherme de Almeida, Centre for translation studies, São Paulo, that featured his translations of Cole Porter songs into Portuguese. Please see Chapter Three, page 150. 
In Chapter Two, I offered a discussion of the various levels of canon theory as they apply to MPB. There exists an overarching Canon of Brazilian popular music, which comprises of the leading figures of this musical category that occupies a middle-ground stature between pop and classical music. The names on this list include almost exclusively those of male singer-songwriter-instrumentalists and a handful of female vocalists. This Canon is host to a number of genres, all of which belong to a class of music that conforms to a series of criteria, or canons. The greater the number of criteria that are met, the more solid is the place of the work, the artist, the composer, within the Canon. The Canon grows and shifts with the passage of time, giving way to additional genres, adapting to the tastes of new generations who require a new definition of Brazilian identity; one that responds to foreign influence with fresh eyes and ears, that allows for a more cosmopolitan view of what it means to be Brazilian. Mistura (mixture) endures as a central value, encouraging the "digestion" of foreign material and cultivating it on Brazilian soil. Mixture and blending are frequently at the heart of new musical material that is considered música popular brasileira. They are key elements that signify authenticity and have been passed down to subsequent generations since the 1930s turn in collective sensibilities about racialized mestiçagem, in spite of the fact that this turn has yet to result in social equality.

With Chapter Three, my goal was to examine in depth the most powerful medium through which the Canon, and the canons, are passed down, that is pedagogy. In this manner, the notion (or construct) of Brazilian popular music 
builds in strength, gaining new constituents, while retaining the status conferred upon it by previous generations.

Chapter Four focused the spotlight on the intérpretes of MPB, and their role as co-creators of musical works. The gendering, racialization and "class-ification" of these roles are always underlying. They too, shift with passing generations, giving way to new subjectivities in the assigned roles, forever contested and reimagined.

In this concluding section, I have chosen four case studies (one of which considers two separate artists) that encapsulate the main discussion points articulated throughout the four chapters of the dissertation. These case studies should be read as vignettes that highlight certain aspects of a performance or recording, to demonstrate, through examples, the interaction of various layers of musical and extra-musical forces. These concluding vignettes will serve nicely as a starting point for further study of the MPB repertoire. In order to guide this analysis, I have defined four parameters with which to study the selected cases. I am indebted to Lori Burns and her colleagues Jada Watson (2009) and Marc Lafrance (2017), for their analytical method that uses crosscutting parameters as a framework for discussing pop songs. Although my application of Burns's analytic matrix must, by necessity, pan out to a broader level of detail on the material at hand, the use of consistent parameters is extremely helpful in providing a nuanced and fair treatment of each of my case studies. My research has relied heavily on the input from interlocutors who are insiders in the São Paulo MPB community, whether they live there, or are simply passing through. These consultants have been my primary authorities on the subject. Interviews and fieldwork, in which I both observed and 
participated, have yielded a great deal of data to mine and I have tried to weave it in throughout the dissertation, so that the reader can see it in its original language as well as English translation. My conclusion is that MPB is a set of canons, but I must ask myself how does it cohere and remain identifiable. How do elements, or examples of music, remain justifiable and identifiable within these canons? What do I include in these canons? I have determined in my previous chapters that there are four guiding principles, or ideologies, that underlie MPB. Although I thought that gender was a guiding principle in itself, I have discovered, in fact, that it is part of the fabric of every aspect of this structure. I am therefore not using gender as one of my analytical parameters, because gender is emerging all the time. It is pertinent in every layer, and intersects with racialization and class differences in very particular ways.

My parameters of analysis are: 1) art value and stature, 2) the composer and "his" work (or the composition), 3) the virtuosic singer, and 4) authenticity. These parameters emerged from the cases themselves, in varying degrees, but allow me to revisit each case with an additional measure of perspective.

\section{Crosscutting parameters used: \\ - art value \\ - the composer and "his" work \\ - the virtuosic singer \\ - authenticity}

The parameter of art value and stature examines the song on the basis of quality and discursive power that is attributed to song, an album, an artist, or a genre. As MPB is 
frequently referred to as "música boa" (good music), one of the questions I repeatedly asked my consultants was "What makes this music good?" Their answers were surprisingly consistent. Whether a song, an artist, an album, a genre, are granted admission to the Canon of MPB depends greatly on their having artistic value. And though participation in the economic system through remuneration for musical work is acceptable, profit and commercialism cannot be the primary motive for the music. Commercialism in MPB is seen as a necessary evil, rather than a raison d'être of the music. This aesthetic element raises the stature of the MPB work through an "art for art's sake" approach reminiscent of Western classical music. Simultaneously, a pro-art value distances MPB from the large-scale industrial considerations characteristic of pop music.

Our second parameter emerges from my observation of MPB as a generally composer-centred practice. A song's primary author is the composer, who, as we have seen, is usually a man. It stands to be said that there is nothing about composition that is beyond the reach of women to an equal degree as men. This is not, after all, pole vaulting or some other physical activity where muscle size and strength are a fact of life. However, as I observed through my fieldwork and interviews, women have historically lacked the opportunity, the recognition, the time and the financial means to produce the same volume of musical composition as men have done collectively, a fact that is amplified for racialized women. That said, my fieldwork also suggests that although there is hope this is changing, there are still vestiges of roadblocks to women writing music or playing an instrument other than the voice. Their presence as composers, such as Beth Amin, still disrupts, even 
though society believes collectively that it is ready to accept them. Like the myth of racial democracy, I fear that gender equality remains to be fully realized. We can on paper declare women's rights and privileges to be equal, but to have it be true in practice is quite another matter. Ron Moy writes a very pithy chapter on gender in Anglo-American pop music. He asks: "Why are men behind the sound of a given year, while women are more typically in front of the mic?" $(2015,23)$. He outlines the strategies adopted by certain women to achieve a level of control over their sound. As I reflect on his observations, it occurs to me that though MPB reinforces stereotypically gendered roles, this can be said of many musical cultures around the world. Music is always already gendered, as shown by numerous scholars (e.g. Burns and Lafrance 2002; Linda Dahl [1984] 1996; Frith 1996; Moy 2015). That said, gender is enacted in particular ways in MPB. For instance, songs that contain gendered pronouns are typically performed in such a way as to maintain the integrity of the text as originally written, regardless of any possible discrepancy between the composer's and performer's gendered or sexual identity. The gendered and sexual identity of the intérprete is not presumed, not does it impede repertoire choice in any way. In order to satisfy the canon of MPB as a composer and workcentred practice, the identity of the singer must be secondary to that of the composer. Furthermore, as we saw in Chapter Four, composers such as Chico Buarque, are known to write from both male and female points of view, without assumptions being made about their personal identity (Braga-Pinto, 2002). As Braga-Pinto points out, "The meanings produced in the slippage between the performer's gender (or sexuality) and those of the poetic voices they perform 
depend on the context defined not only by the artist, but also by the media and the public" $(2002,193)$.

The emphasis on the composer is an aspect that elevates MPB above the level of the pop song and closer to the level of art song. MPB's emphasis on the composer and the song, while the intéprete is at their service, is part of the rapprochement of MPB to a classical music level of sophistication. Bossa nova era composers adopted the composer-centredness of a European post-1800 mentality. And like the workconcept has been applied after the fact to pre-1800 compositions in the Western European classical tradition, the same has occurred in pre-bossa nova MPB.

The parameter of the virtuosic singer refers to the necessity of a certain level of virtuosity to sing MPB songs. Although many of my informants insist that a "good singer" need not have the technical prowess that would be valued in "música erúdita" (erudite music), MPB singers must be able to perform with accurate intonation in music that is written with a great deal of challenging chromaticism. So while the timbre used to sing MPB varies greatly, and allows for the use of vocal textures such as raspiness, chest tone resonance and a more conversational approach to phrasing, it is nevertheless expected that the singer will control her vibrato, which has the effect of differentiating MPB singing from a classical approach. Virtuosity in the MPB sense, has a different sound than classical virtuosity, but is nevertheless a high degree of control over the instrument. The singer must be able to improvise a phrasing that is all her own, while "respecting" the composer as the primary author. Once again, we see how MPB establishes a middle position between classical and pop. This parameter of virtuosic singing does 
not apply equally to all singers, but rather those who consider themselves intérpretes, which is by and large the feminine contingent of vocalists. As my consultants made very clear, a different standard of singing is applied to those who also compose their own songs (i.e. male singers). I am afraid that the composer status is perhaps a smoke screen for what is actually a sexist double standard, given the experience of watching a female composer get criticized publicly for her lessthan-perfect vocal technique.

The parameter of authenticity alludes to who and what can be considered authentically Brazilian in order to qualify in the MPB category. This is largely achieved via an element of mestiçagem, in particular the measure of Africanness that is necessary to differentiate Brazilian music from a strict European background. In addition, this parameter references the "popular" aspect of the music. That is, MPB is constructed as a music "of the people," rather than belonging to upper strata of cultural taste associated with European classical music. Oddly, MPB achieves a distancing from both Western classical music, and lower class taste aesthetics associated with pop genres. The parameter of authenticity, therefore, cuts across culture and class. As is the case in jazz (Beausoleil-Morrison 1999), MPB is a middlebrow music that is fancied as an erudite expression in a popular realm with African "roots." In Brazil, the cradle of African culture, and therefore authenticity, is often located in the Northeastern part of the country.

\section{Case study 1: Mônica Salmaso and 'Trem das onze'}


My first case study is a song called "Trem das onze" (Eleven 0'clock Train) recorded by Mônica Salmaso on her 2011 album Alma Lírica. This album was attributed cultural and artistic value, as it won Salmaso the award for best MPB singer in the 23 ${ }^{\text {rd }}$ Prêmio da música brasileira (Brazilian Music Award) in 2012. In September of 2013, I attended a concert in Ottawa, sponsored by the Brazilian embassy, named "The Soul of Brazilian Music" (Alma Lírica), where Salmaso performed the music from this very album. Not coincidentally, the concert was presented in connection with Brazilian Independence Day (September $7^{\text {th }}$ ). Art value was conferred on Salmaso by virtue of her performance of material that is deemed national. Near the end of the show she said that she was happy to share this music: "To play our Brazil for you. We love our country..." and she went on to describe the pleasure of sharing Brazilian music.

Turning to the parameter of the composer and "his" work, "Trem das onze," was the last song performed during Salmaso's 2013 Ottawa concert, and is the last song on the album. It was composed in 1964 by Adoniran Barbosa, who was, according to Severiano, the most popular composer in São Paulo in the 1950s (2013, 276). I would like to point out that Salmaso was the only lady on the stage that night, and that her group performed nineteen pieces. In the entire program only one song was written by a female composer, Violetta Parra of Chile, and one song is attributed to a female Brazilian lyricist, poet Dora Vasconcelos. All remaining selections were composed by male Brazilian authors, including her accompanying pianist, Nelson Ayres. All the authors' names appear in the program, a practice Michael Talbot points out began in Western Art Music after a turn toward composer-centredness 
post-1800. Before that, it was much more commonly the case that the composer was completely eclipsed by the on-stage performer $(2000,177)$.

As for the virtuosic singer parameter, the Brazilian ambassador introduced Salmaso himself, describing her as a young singer of major importance in Brazil, and as a bossa nova artist. He described Salmaso's voice as "légèrement gutturale" (lightly guttural), which, having heard the performance myself, I interpret as referring to her ease of access to her low range combined with the slight airiness in her vocal sound. Based upon my own listening to her performance in Ottawa, I offer the following observations.

- Salmaso has exquisite control over her instruments, the voice most of all;

- Her rhythmic sense is precise;

- She has a huge vocal range and her sense of pitch is well-defined and unforced at both top and bottom;

- She negotiates complex melodies with ease;

- Her vocal production is unforced, relaxed in the throat, while slightly airy. This minor airiness just roughs up the edges of the sound somewhat, providing a contrast to the purity of the tone she is producing;

- The voice is light in texture and volume, but resonates with a rounded tone at the same time. I believe this is accomplished through the use of full resonance, with a relaxed larynx, and piano or mezzo-piano dynamics;

- Unlike the more typical mixing of prominent lead vocals with other instruments further in the background, Salmaso sings at a level closer to the overall texture;

- Her percussion performance is subtle, sometimes sounding very soft, just a little "tick-tick, tick tick tick";

- The trio is well rehearsed and the members know each other's every move. They are very much "together" musically, and the interpersonal dynamic is loving and easy.

- She acts out a lot of her lyrics with her body language, and is often funny. 
Salmaso inserts herself into the song in various ways, but always with great deference to the composer's intention. Lyrically, she leaves out the initial vocable section ("Quais, quais, quais, quais...") that was performed at by the original performers of this song, the Demônios da garoa. ${ }^{67}$ As is common in MPB, Salmaso maintains the gendered pronouns from the lyric, thereby singing the song from the male point of view. The line that establishes the gendered perspective is the first phrase of the refrain, which says: "Sou filho único. Tenho minha casa pra olhar" (I am an only son. I have a household to watch over.) The song's protagonist is explaining that he "cannot stay another minute" because if he misses the last train home, his mother will worry, and he has a household to keep. At the very end (3:40 on the recording), Salmaso sings instead: "Temos filho único. Temos nossa casa pra olhar" (We have an only son. We have our house to watch over.) The "we" she is referring to includes herself and the baritone saxophone player, who is also her husband. By inserting this line in a canonical song, she is signifying on a personal level, adding a touch of humour, and also engaging in an act of musical empowerment.

A sense of authenticity is achieved throughout this concert as well as the album, through the performance of canonical material. Salmaso's performance highlights national identity by indexing what is often referred to as the "cradle of Brazilian culture," that is Northeastern Brazil. Although the program included many genres of popular music from the 1930s to the present, the ambassador made a point of mentioning baião and forró, which are genres from the Northeastern part of Brazil. "Trem das onze" is a samba about the city of São Paulo, with lyrical references

${ }^{67}$ Please see https://www.letras.mus.br/demonios-da-garoa/635205/. 
to specific parts of the city. Closing the concert and the album with a samba, the official national genre, and one that is set in the largest metropolis in Brazil, adds legitimacy to the performance. And since São Paulo is Salmaso's hometown, it also adds a personal touch.

\section{Case study 2: Fabiana Cozza - Canto Sagrado}

As a samba singer, Fabiana Cozza has art value bestowed on her by the very fact of being recognized as an MPB singer. Like Mônica Salmaso, Cozza also won an award in the $23^{\text {rd }}$ Prêmio da música brasileira (Brazilian Music Award), but for best samba singer, for her eponymous album released in 2011. Although this award separates MPB and samba into different prize categories, Cozza's approach to samba is one that has been acknowledged as blurring those distinctions, as we saw in Chapter One. As the write-up to the 2016 SESC concert with Ceumar and Mônica Salmaso states:

No mesmo período [os anos 1990], Fabiana Cozza, filha do sambista Osvaldo dos Santos, apresentava ao público sua mistura de samba e $M P B$, que lhe renderia prêmios e reconhecimento. (SESC Brasil 2017)

In the same period [the 1990s], Fabiana Cozza, daughter of sambista Osvaldo dos Santos, was presenting her mixture of samba and MPB to the public, which garnered her prizes and recognition. (SESC Brasil 2017)

Not all samba singers are considered MPB. Albeit the national rhythm, samba can also be heard as a club dance style, music from the favelas and carnival schools, all of which imply a lower class standard and unfortunately loaded with racialized 
history. However, Cozza distinguishes herself by "measuring up" to other criteria, such as vocal and interpretive virtuosity. Her 2013 album Canto Sagrado (Sacred Song) is subtitled "Uma homenagem a Clara Nunes" (A homage to Clara Nunes). Nunes is credited as one of three samba singers from the 1970s, alongside Beth Carvalho and Alcione, to have raised the level of prestige associated with the samba genre (Severiano 2008, 428). By aligning herself with this genealogy of singers, Cozza distances herself from any of the lower class connotations of the samba genre. There are twenty composers represented on this album. Glorinha Gadelha is the only female composer on the CD. The list of composers includes some who are said to be "deeply rooted in the samba tradition" (Discogs 2017), such as Paulinho da Viola. It also includes composers representing other genres, such as Candeia, in samba and choro; the "King of baião," Luiz Gonzaga; and Chico Buarque, a widely acknowledged MPB composer. That said, the authorial foregrounding emphasizes Clara Nunes, who is the inspiration for the album. This suggests a much more performer-based authorial focus.

Cozza's virtuosity comes through in her clear intonation, impeccable rhythmic sense, controlled and easy access to all parts of her respectable range. Her interpretive style features improvisatory phrasing that is rooted in the rhythm of the language. She has formal dance and theatre training, which add a great deal of grace and style to her performance persona on stage, as I am able to discern from watching YouTube videos of live performances. She is also able to negotiate a variety of vocal productions, from the typical style of samba singing, with open 
throated chest tone often associated with African-based genres, to softer volume singing that is a mark of sophistication since the advent of Bossa Nova.

Although I did not have the pleasure of attending one of Cozza's

performances in person, nor did I meet her, I feel she is a very important case to consider because of what she brings to the authenticity question. She is the daughter of a sambista Osvaldo dos Santos, who was one of the lead singers for Camisa Verde e Branca (Green and White Shirt), an important samba school in São Paulo. Her albums index her Afro-Brazilian heritage in many ways. Canto Sagrado alone contains several references to the Northeast, which was the main point of entry for African slaves and the part of the country with the largest Afro-Brazilian population. It is often viewed as the hotbed of authentic Brazilian culture, and the incubator of samba, the creators of which were workers who had migrated to Rio from the Northeast. Northeastern rhythms such as xote, maracatú and baião are even mentioned by name in the lyrics to "Pau de Avará" (Palm Tree Branch). The song "Congada" 68 is about the music of the Northeast. The song title "Ijexá" is the name of Pernambucan ${ }^{69}$ rhythm called afoxé. "Candongueiro" (The Smuggler) lyrics refer to slave history and roots in Angola. "Canto das três raças" (Song of three races), refers to the plight of workers of all "colours."

As Sterling highlights, "blackness" is paradoxically a marker of Brazilian authenticity, while Afro-Brazilians still suffer from economic disadvantage, discrimination and violence to a disproportionate degree $(2012,5)$. By indexing her Afro-Brazilian heritage as strongly as she does, Cozza is resisting cultural hegemony

${ }^{68}$ A congada is an Afro-Brazilian street pageant (Vianna [1995] 1999, 69).

${ }^{69}$ Pernambuco is a Northeastern state in Brazil. 
through pride and self-identification, an exercise some would say is still necessary, so long as there is inequality (Andrews 2004, Dixon and Burdick 2012). Authenticity is bestowed upon her as a result of her Africaneity. Cozza also engages an authenticity of a personal nature, by performing the music of her choosing whether it be labeled samba, MPB, Latino or otherwise. Much as Santhiago describes in his study on Afro-Brazilian non-samba singers (2011), Cozza would likely have been typecast early on as a samba singer. Thankfully recognized for having broad ranging talents, she seems to have managed, in her last two albums, to find a balance between embracing her heritage and not being pigeon-holed into a specific family of genres from the Northeast. Her 2015 album, Partir (To Leave), still contains many markers of Northeastern music in its rhythms and lyrics, but seems less circumscribed than her earlier albums in terms of the arrangements, textures and instrumentation. Cozza's 2017 album, Ay Amor, explores Spanish Latin-American songs, and even includes one song in French and one in English. Further study of her body of work would be a very fruitful endeavour.

\section{Case study 3: "Modinha" as performed by Lívia Nestrovski and Luciana Souza}

This case consists of comparison of two versions of the same song, namely "Modinha" by Antonio Carlos Jobim, as sung by Lívia Nestrovski and Luciana Souza, on their albums coincidentally entitled "Duo" and "Duos II" respectively. In terms of art value and stature, this comparison can yield some clues as to the basis upon which discursive power is granted. As discussed in Chapter Four, Souza is 
considered to be a jazz singer, rather than an MPB singer. Nestrovski, on the other hand, is unequivocally an MPB singer, and is rising in ranking as part of the new generation. She and her duo partner-husband, Fred Fereira, were the hosts of the SESC concert “Vozes que Interpretam o Brasil” (Voices that Interpret Brazil) discussed in Chapter One. Nestrovski is quoted as saying: "Elas [Ceumar, Cozza e Salmaso] nos ensinaram a fazer música também e passam pela nossa história" (They [Ceumar, Cozza and Salmaso] taught us to make music as well and they do so through our history) (SESC Brasil 2017). As well as co-producing the show, Nestrovski performed alongside the senior vocalists. By associating herself with these singers from the 1990s generation, Nestrovski is positioned as the up-andcomer.

Souza, who has resided in New York for many years, has achieved very high stature in North America. She has been nominated seven times for Grammy awards in the jazz category since 2002, and has won once for her participation of Herbie Hancock's River: The Joni Letters in 2005 (Recording Academy 2017). Considering how much of her work is sung in Portuguese, the very close historical connection between jazz and MPB in Brazil, and given the number of consultants who clearly stated that anything sung in Portuguese can now be considered MPB, and the unquestioned quality of the music she produces, I find it puzzling that the discursive power of the MPB category is withheld from this native of São Paulo, and why Brazilians would hesitate to claim her as one of their own as a point of pride. Joni Mitchell will always be Canadian, no matter how long she lives in the United States. 
If we turn to the composer question, both Nestrovski's Duo and Souza's Duos II albums contain and equal measure of material from canonical MPB composers, such as Milton Nascimento, Antônio Carlos Jobim, Dolores Duran, Paulinho da Viola, Chico Buarque and Caetano Veloso, to name a few. Out of ten selections on Nestrovski's album, there is one song by a female co-author. Out of twelve selections on Souza's album, there are three that feature women as secondary authors, and one original song by Souza herself. Jobim and de Moraes's "Modinha" was first released in 1958, by singer Elizeth Cardoso, just as the bossa nova movement was about to take hold. Many people, including Brazilian superstar Elis Regina, have sung "Modinha".

Encyclopedia Brittanica defines a modinha as:

[A] light and sentimental Portuguese song popular in the 18th and 19th centuries. ... Originally simple melodies, modinhas often were embellished with intricate and elaborate musical effects when performed at court or for the nobility. Modinhas were introduced in Brazil in the late 19th century, where they remained simple expressions of urban life. (Encyclopedia Britanica 2017)

This particular modinha is in keeping with the traditional variety in that it is a sentimental love song. The intricate and elaborate musical effects are written into the composition. It is a highly chromatic setting of Vinícius de Moraes's love poetry that requires a singer who possesses excellent intonation, range and breath control. Nestrovski and Souza are both highly qualified for the task.

Nestrovski's version is attached to another Jobim song "Estrada do sol" (Highway of the sun), which is co-written by Dolores Duran. At the end of Estrada do sol, guitarist Fred Fereira plays a sixteenth-note ostinato pattern on a single note 
while Nestrovski launches into a slow and sparing rendition of the melancholy chromatic line of "Modinha," with absolute accuracy. Her interpretive phrasing is achieved mainly through dynamic inflection inspired by the rhythm of the words. As Nestrovski shared with me, her goal in singing bossa nova music is to denude the interpretation of any excess. I include here an extensive quote because I feel she expresses very clearly why some may feel the jazz approach may differ from a bossa nova (and by extension MPB) approach.

Quando o Tom Jobim escolha uma nota, essa nota tem que ser aquela nota. Eu volto a essa questão do intérprete; de entender que não precisa mudar aquela nota de lugar, que é uma coisa que no jazz se faz muito. E muita gente associa a bossa nova ao jazz por caso da harmonia, que é uma visão europeia da música. Então eu acho que não é isso. Bossa nova não é só harmonia, e bossa nova não é jazz, embora tenha correlação. Os músicos da bossa nova foram muito influenciados por jazz também. Mas não é jazz. Não é um "jazz com letras português." E é isso que eu acho que tem que ser deixado muito claro. Na composição da bossa nova, se você tira o arranjo e pega só violão e voz, que é o que João Gilberto passou a fazer depois, apenas sem orquestra, sem banda, sem nada, só ele, violão e voz, é isso. É essa crueza. Ele está fazendo esse papel que eu disse que seria o primeiro passo do intérprete. Ele está "enxugando" a canção. Você ouve a canção. Você ouve toda a relação entre harmonia, letra, e melodia. Eu acho que isso foi um papel fundamental do João Gilberto. E pra mim bossa nova tem todo a ver com isso. Quando se pega Leny Andrade ${ }^{70}$, ela é o oposto do João Gilberto. Ela muda a melodia. Ela improvisa em cima. A bossa nova não, em geral, não pressupõe muita improvisação. Pelo menos nesse início os discos do Tom Jobim não têm improvisação. Não têm. Agora, da Leny Andrade têm, e do Johnny Alf. Ou é um outro lado que aí, eu acho que deveria ter um outro nome. Que eu dei de "samba-jazz," seguindo uma corrente de gente que está estudando esse estilo, mas que ainda não tinha muito um nome definido. Eu acho que é uma outra coisa, que conversa com a bossa nova, mas tem outra forma de abordar o repertório. Tem um repertório às vezes é o mesmo. Por isso que eu acho que a Leny Andrade se define muito como uma cantora de bossa nova. Só que a

\footnotetext{
${ }^{70}$ The reader may recall Leny Andrade is one of the senior MPB artists mentioned in Chapters One and Two. Nestrovski wrote her master's thesis on the improvisations of Leny Andrade and therefore uses her as an example.
} 
abordagem dela é muito mais jazzística do que cancional. Pra ela não tem importância assim mudar melodia, mesmo que seja Tom Jobim. É isso é uma visão dela, e pra ela isso é bossa nova. Mas pra mim é samba-jazz.

When Tom Jobim chooses a note, that note must be that note. I return to that question of the intérprete; of understanding that they don't need to change the place of that note, which it is something that is done a lot in jazz. And many people associate bossa nova with jazz because of the harmony, which is a European vision of music. So I find that that's not it. Bossa nova is not only harmony, and bossa nova is not jazz, even though there is a correlation. Bossa nova musicians were very influenced by jazz also. But it isn't jazz. It is not a "jazz with Portuguese lyrics." And this is what I find must be left very clear. In the composition of bossa nova, if you take away the arrangement and take only the guitar and the voice, which is what João Gilberto started doing after, barely without an orchestra, without a band, without anything. Just him, his guitar and his voice. That's it. It is this rawness. He is performing this role that I said would be the first step of the intérprete. He is "wiping the song clean." You can hear the song. You hear the whole relation between the harmony, the lyrics and the melody. I think this was the fundamental role of João Gilberto. And for me bossa nova has everything to do with that. When you take Leny Andrade, she is the opposite of João Gilberto. She changes the melody. She improvises over it. Bossa nova doesn't, in general, does not presuppose much improvisation. At least at the beginning, the records of Tom Jobim don't have improvisation. They don't. Now, those of Leny Andrade do, and those of Johnny Alf. ${ }^{71}$ Or it is another side that, I think, there should be another name, that I would call "samba-jazz," following the current of people that are studying in this style, but who still don't really have a defined name. I think that it is another thing, which converses with bossa nova, but has another kind of approach to the repertoire. There is a repertoire that is sometimes the same. That's why Leny Andrade defines herself very much as a bossa nova singer. Only that her approach is much more jazzoriented than song-oriented. For her, changing the melody doesn't matter, even if it is Tom Jobim. And that is her vision. And for her that is bossa nova. But for me it is samba-jazz. (Personal interview, July 15, 2015).

Although she acknowledges the relationship between bossa nova and jazz, she believes that the improvisational aspect is the factor that distinguishes the genres.

${ }^{71}$ Johnny Alf was a singer and one of the precursors of Bossa Nova. 
Nestrovski's comments show us what a contested zone bossa nova can be. I would venture to suggest that given the breadth of genres included in MPB, that there would be a space for what Nestrovski would call samba-jazz within that umbrella. This reinforces my feeling that there is a political aspect to the insistence by my Paulista contacts that Souza be labeled a "jazzer," rather than an MPB singer. Nestrovski's reflections also demonstrate the importance of the composer and his work in MPB. The virtuosic singer, remains at the service of the composer. Their individuality as interpretive artist comes through in the differences in lyrical declamation, dynamic inflection, very slight rhythmic shifts that imitate the spoken language.

Souza's version of "Modinha" can be said to follow this model of the "jazzistic" approach to the Jobim song. She sings through the form twice. The first time, she sings it with a great deal of loyalty to the written melody and rhythm. It could be argued that she is extremely respectful of the composer's wishes. Her pitch is outstanding and she uses a vocal production that is very much in keeping with the bossa nova school of singing, subtle and soft, in an intimate speaking tone with accurate intonation. Her breath control is exquisite. Her vocal inflections also emphasize the text, conforming to the contours of the Portuguese language, but with a signature that is certainly her own. The second time through the form, Souza improvises using scat syllables that arguably stem from Portuguese pronunciation, with Portuguese-sounding vowels, soft "l" consonants, and rolled "r" consonants. I have heard these types of syllables used by other Brazilian singers, but never by North American jazz singers. Souza tastefully fills the first phrase with ballad- 
appropriate sounds that complement the single acoustic guitar accompaniment in "jazzistic" conversation. She then displays well-honed breath control by holding her last improvised note until it morphs into the first note of the first phrase starting with the syllable "ah." From a vocal technique standpoint, this requires a great deal of practice and know-how.

The question of authenticity is raised by the comparison of these two versions of "Modinha." Nestrovski and Souza both have led what might be called a transnational existence. Souza, as we have seen, has spent most of her adult life in New York, although she did return to Brazil in the early 1990s to teach at UniCamp. Nestrovski's was born in the United States. She spent the better part of her childhood between São Paulo, Porto Alegre, and Indiana. She describes it as "kind of a global life" (Personal interview, July 15, 2015). She finally returned to Brazil and makes her living as an intérprete and teacher, based in both Rio and São Paulo. The transnational meets the authentic in these two examples, highlighting the constructed nature of the national and the political construct that is MPB. In this comparison, we come face to face with a Brazilian ambivalence toward foreign influence, particularly that of the United States. And yet, it seems to be in the very mixture of genres that brazilidade resides. We can feel from Nestrovski's comments above, that there is a real resistance to the notion that bossa nova would be viewed as a mere translation of jazz into Portuguese. Once again, the feeling of national pride and the value that national music holds for her is foregrounded. However, she herself has been greatly influenced by jazz. She explains:

Eu comecei me interessar por jazz, primeiro, antes de música brasileira. Como eu ouvia em casa canções brasileiras, conhecia o 
repertório, mas eu gostava de cantar música americana, porque eu aprendi lá. Daí pro jazz, foram passos curtos, e muito perto. E aí me apaixonei por jazz. Meu pai me deu disco da Ella Fitzgerald, e eu descobri um outro na Sarah Vaughan. E aí fiquei apaixonada. E aí comecei a ouvir aqui, e gostar, e tal. E eu estudei um pouco de piano, canto. E aí depois entrei na faculdade, na UniCamp. É lá que eu foi me interessar pela música brasileira. Nessa época já cantava profissionalmente nos bares da região. Com 17 anos eu comecei a ganhar dinheiro cantando. Não cantava pelo dinheiro mais ganhava dinheiro cantando. Então já queria ter como profissão, já sabia, já estava certa daquilo. E comecei ali, 17 anos, a me profissionalizar. Com 18, entrei na faculdade. E aí através da Regina Machado, que foi minha professora durante os quatro anos da faculdade, eu descobri a música brasileira. E aí depois eu vim pro Rio assim que eu me formei. E aí acabei fazer um mestrado aqui também. Eu queria em fazer essa ponte assim de São Paulo. (Personal interview, July 15, 2015)

I started to get interested in jazz, first, before Brazilian music. As I heard Brazilian songs at home, I knew the repertoire, but I liked to sing American music because I studied there. From there to jazz, they were short steps, and very close. And I became impassioned with jazz. My father gave me an Ella Fitzgerald record, and I discovered another by Sarah Vaughan. And then I became impassioned. And then I started to listen, and enjoy, and so on. And I studied the piano a little bit, and singing. And then after, I entered the faculty, at UniCamp. It is there that I got interested in Brazilian music. At that time I sang professionally in local bars. At 17, I started to earn money through singing. I did not sing for money but I made money singing. So I wanted to have this profession, I already knew. I was already certain of that. I started there, at 17 , to professionalize. At 18, I entered the faculty. And there, through Regina Machado, who was my professor for four years at the faculty, I discovered Brazilian music. And then I came to Rio, and that's how I got trained. And then I ended up doing a Master's degree here too. I wanted to make a bridge that way, from São Paulo. (Personal interview, July 15, 2015)

In these comments, we see the importance of the Rio-São Paulo axis of urban music.

We see the trajectory between jazz and Brazilian song as being very close. We see the search for a personal identity rooted in national music. We can observe the generational transmission of learning and belonging. Furthermore, we see the importance of the pedagogical cycle in the formation of that national identity. We 
see the importance of making a living at music, while maintaining that money is not the primary motivator for the music itself. We see a trajectory of professional training on the job, leading to professionalized training at the university level.

A note-for-note comparison of Nestrovski's and Souza's versions of "Modinha" would show the subtle variations that make each performance stand out as a unique interpretation of a canonical song. And though both singers are extremely respectful of the composer's intentions, both achieve a very different result. Furthermore, we can perceive how a transnational life and career trajectory can offer a different result in the attribution of discursive power, where one is accepted as a Brazilian singer at home, and the other is lauded as a Brazilian singer abroad, but not at home.

\section{Case study 4: 'Complexo de épico’ as performed by Regina Machado}

Our final case study pertains to Regina Machado, who studied briefly with Luciana Souza, in the early days of UniCamp's popular music program, and was a teacher of Lívia Nestrovski several years later at the same institution. Machado's latest recording, released earlier this year, is an album entitled Multiplicar-se única, which is dedicated entirely to songs by composer Tom Zé. I have discussed Machado in every one of my chapters, as her presence in the São Paulo MPB community is felt in so many ways, as a performer, professor, researcher, private teacher, music school owner and founder. Her master's thesis on the work of the Vanguarda Paulista (Paulista Vanguard) was published as a book, and she completed her PhD at the University of São Paulo in 2012 on the work of Luiz Tatit, who was discussed in 
Chapter Two. She leaves no doubt as to her dedication to what she describes as "urban Brazilian singing," (Machado 2012) and is well recognized as one of its strongest champions in São Paulo. All my consultants know of her and speak highly of her stature in the field. Multiplicar-se única is her fourth album since her first was recorded in 2000, and takes her full circle in the sense that she began her professional singing career in the 1980s as a back-up vocalist for composer Tom Zé (Personal e-mail, September 7, 2017).

The compositional emphasis is highlighted in this case by album's focus on the single author. Tom Zé was, and is, a major figure in the Tropicália movement of the late 1960s, which, ironically was very much about "decomposition." Christopher Dunn explains that Tropicália was "a pastiche of styles, both new and old, national and international" $(2001,3)$. Tatit states:

Pode-se dizer que, ao contrário do procedimento habitual dos cancionistas de estetizar o cotidiano, Tom Zé "cotidianizava" a estética: inseria as imperfeições, as insuficiências, os defeitos.

It can be said that, to the contrary of the usual procedure of songwriters to aestheticize the quotidian, Tom Zé "quotidianized" aesthetics: inserting imperfections, insufficiencies, defects. (2004, 237)

Tatit quotes Zé directly, saying that he was seeking to disrupt notions of beauty by producing "descanção" ("dis-song") $(2004,238)$. Despite this approach, which was in large part politically motivated by protest to the dictatorship, Zé and other proponents of Tropicália are very much a part of what today is considered MPB, and continue to be canonized by albums such as Machado's, that celebrate their stature in the Brazilian cultural arena. It bears noting that the two women who are most often mentioned in relation to the Tropicália movement, Gal Costa and Maria 
Bethânia, are intérpretes. And although they are revered, they have never achieved equal status to composers (who also sing), such as Gilberto Gil, Caetano Veloso and Tom Zé, who are considered the true authors of their songs.

The song "Complexo de Épico" (Complex of the Epic), relates in ironic terms how "All Brazilian composers have a complex,"72 and that that they are too serious about everything. It talks about the preoccupation Brazilian composers have with being great, and belonging to the educated classes. The most serious commentary within the song can be loosely translated as comparing the composers in question to a cobra that is devouring itself by the tail, becoming at once hunger and food. The song ends with a refrain that features a final sarcastic question about whether life will be that serious in Hell. I find this song says a lot about the Brazilian cultural tendency to value composer so highly. It is at once poking fun at itself, while enacting the very complexity it seeks to mock. It is at once an argument against taking oneself too seriously, and an embodiment of the same. The poetry is extremely pithy, politically charged and recherché, and yet its content contradicts that notion. It is brilliant!

"Complexo de épico" does not require any particular vocal technique to sing, and features one single repeated guitar chord, a dominant seventh, throughout. Zé himself sang the original recording, released in 1973. In the original recording Zé performs in a half-sung, half-spoken style that obscures any semblance of form, and leaves in some extraneous spoken words that he seemingly mutters to himself. It

\footnotetext{
${ }^{72}$ For full lyrics of this song, please see https://www.letras.mus.br/tom-ze/164875/.
} 
even includes what sounds like a glitch in the lyric performance. In this sense, Zé's recording performs the message of the song.

Machado's version displays her interpretive virtuosity in a vocal approach that brings forth her own conversation with the material, with the "work" itself, as much as being an interpretation of the narrative at hand. Machado's version of this song is just under half the length of the original. She uses two very different types of vocal production, either sung or spoken, or in this case head or chest tone respectively, to differentiate between the formal parts of the text. Her pitch is precise, unlike that of her mentor and muse, Tom Zé. I am reminded here of Joana Mariz's observation that Brazilians do not expect composers to have as honed a sense of vocal intonation as intérpretes. And Machado's own personality and uniqueness come through very clearly, particularly in the sections that are loaded with irony. She transitions between sung and spoken word with absolute ease, accessing different resonating parts of her voice. Her version features a rock groove that recalls Tropicália's embracing of international influence, or by Machado's description, “Rock brasileiro tropicalista!” (Tropicalist Brazilian rock!) (Personal email, Sept. 7, 2017).

Authenticity is achieved in this case, by virtue of the connection between the present recording and one from a defining period in Brazilian music history. Luiz Tatit describes the bossa nova and Tropicália period of the 1960s as "o nó do século" (the knot, or nucleus, of the century) $(2004,177)$. He also states:

... Tom Zé personificava o Brasil - sem qualquer estereótipo de "autenticidade" regional - seguindo acintosamente uma trilha própria, construída nos vãos desprezados pelas iniciativas internacionais. $(2004,239)$ 
... Tom Zé personified Brazil - without any stereotype of regional authenticity - intentionally following his own path, built on the despised interstices by international initiatives. $(2004,239)$

These comments allude to the notion of the Northeast as the hotbed of Brazilian authentic culture. They also help to reinstate the composer into a canon, from which he had been excluded for many years on account of his somewhat heretic approach to music making, which made him less attractive in a risk-averse music industry of the time (Tatit, 2004, 238).

\section{Final remarks}

Taken together, these emblematic case studies show that there is not one single way of singing that can be called Brazilian, but rather many different ways that are associated with particular lineages of Brazilian song. These lineages are defined by genre considerations, often defined by social distinctions along racialized lines, which intersect with class distinctions, and are always underlined by gender.

These cases also highlight the fact that MPB singing has undergone, and continues to undergo, a process of professionalization. From the inception of the first university-level popular music program in 1989 until now, there seems to be an eagerness to teach young students Brazilian music traditions through listening, while encouraging experimentation and diversity. There is hope, albeit faint, that this professionalization brings with it a levelling of the playing field, allowing for more integration of musical roles amongst men and women, among people of different cultural backgrounds, and among people of different classes. 
The case analyses also put into relief the fact that quality is a core value MPB music making, and that vocal virtuosity need not be the province of classical singing alone. When seen through the lens of interpretation, fine nuances and personal character can add a whole new colour to a song, and contribute to its overall creation as a performative act.

As mentioned in Chapter Three on the popular music pedagogy, there is a good deal of confusion, even on the part of insiders, as to how one label-"MPB"can be applied to such disparate sounds. My research indicates that the main reason for this "genre confusion" is that MPB is not a genre at all, but rather a set of canons. It includes a number of diverse modes of expression and performativity. It includes a number of genres and styles. All the musicians that I met in the MPB community of São Paulo were genuinely concerned with making good quality music, first and foremost. And while it is not the most "popular" of popular musics, MPB preserves a sense of art value that lies beyond numbers. The canons of MPB are perpetuated and preserved by a combination of nostalgia, national pride and a need to belong on the world stage. Put another way, MPB provides a structure from which to build a sense of national identity and belonging in the world through a popular music practice. In addition to easing the burden of pedagogues by offering a ready-made curriculum to teach, canons serve to protect the quality of MPB by creating links between musical values and the artists that embody them. By holding up certain artists, canons hold up the work that they do, and provide a model of quality-a standard for which to strive. Canons also serve to conserve musics that fall out of fashion through industry pressures and generational tastes, protecting their place in 
history and public consciousness. By establishing a genealogy of artists and a continuous narrative, albeit shifting and ever-broadening, of styles and genres that speak to each other, and that signify Brazilianness collectively, MPB maintains a much larger purpose of giving Brazilians a positive sense of belonging. Odd as it may seem, even for those who find themselves on the margins of the Canon, as either audience or practitioner, carry an awareness of certain musics that represent the nation on a broader scale. Knowing a repertoire that is commonly shared and to which everyone knows the words, growing up with its sounds, means that anyone adopting any type of music does so in the context of MPB, giving them something against which to rebel, on which to comment, from which to quote. So to say that MPB is Brazilian music is not to say that Brazilian music is homogeneous, but rather to acknowledge that over time, this Canon has come to define Brazilian culture in much the same way as soccer, carnival and feijoada.

MPB canons provide the framework, the set of criteria to differentiate it from outside cultural sources, or "invasive species" like rock and hip hop, that it may even "digest" into the fold of Brazilian musics. There is a constant tension between what is "true" Brazilian music and what can be borrowed from outside musical cultures, but once a sound is integrated into the canons of MPB, it is claimed, like land, in the name of MPB, and owned. The canons make it possible to take possession of exotic musical sounds, process them and claim them as part of Brazilian national identity. Some people refer to this process as musical anthropophagy, or cannibalism (Ulhôa 1995). I prefer to think of it as analogous to linguistic borrowing, that becomes part of the language. For better or worse, the idea of mistura (mixture) that suffuses 
Brazil's racialized social history, imbues MPB in ways that both reflect and participate in the construction of Brazilian identity.

That said, a significant, if unintended, effect of canons is to create, and even to camouflage and maintain, a very real hierarchical authorial structure that places composers first and singers second. Taking gendered subjectivity into account, this means that men are at an advantage in terms of recognition. Furthermore, racialized groups must navigate this labyrinth on more than one plain simultaneously, finding a place in the canons that allows them to perform, while accepting the limitations placed upon them by highly circumscribed roles.

I am very grateful for the opportunity to participate in the many passionate and forthright discussions that gave rise to most of the ideas put forward in this study, and I take full responsibility for anything I may have misunderstood. As a French-Canadian vocalist, living so close to the border with the United States, with all the advantages and disadvantages that entails, I have a great deal of respect for people who strive to maintain their uniqueness and identity in what is no doubt a competitive global musical landscape. And I fully appreciate the ambivalence produced by such a climate. On the one hand, a national Canon of popular music is problematic in the power structure it creates, and on the other, it provides a beacon of identity and belonging. Drawing attention to the myriad ways in which intérpretes of MPB signify the nation through their vocal sound, can help to rebalance some of the inequities of power that have pervaded MPB history. If nineteenth century scholar Ernest Renan was correct, in that "forgetting is a crucial factor in the creation of a nation" (cited in Loomba [1998] 2005, 163), then 
remembering, may hold the key to the renovation. As we say in my native Québec, "une femme avertie en vaut deux" (An alerted woman is worth two). With eyes wide open to the advantages and pitfalls of the MPB canons, it becomes possible to appreciate the breadth of musics that comprise this category, and even negotiate better terms for those whose voices are front and center in its sound. 


\section{References}

Abbate, Carolyn. 1993. "Opera, or the Envoicing of Women." In Musicology and Difference: Gender and Sexuality in Music Scholarship, edited by Ruth A. Solie, 225-258. Berkeley: University of California Press.

Amin, Beth. 2013. "The Brazilian Way of Singing." Presented at the Panamérica Canção (Panamerican Song) Project Symposium at Carleton University, Sponsored by the Universidade de São Paulo (University of São Paulo), Ottawa, March 22, 2013.

Andrews, George Reid. 2004. Afro-Latin America, 1800-2000. New York: Oxford University Press.

Anderson, Benedict. (1983) 2006. Imagined Communities: Reflections on the Origin and Spread of Nationalism. Rev. ed. New York: Verso.

Aparicio, Frances R. 1998. Listening to Salsa: Gender, Latin Popular Music, and Puerto Rican Cultures. Hanover, NH: University Press of New England.

Avant-Mier, Roberto. 2011. "Of Rock and Nations: Voces Rockeras [Rock Music Voices] and the Discourse of 'Nationality.'" In Latina/o Discourse in Vernacular Spaces: Somos De Una Voz?, edited by Michelle A. Holling and Bernadette Marie Calafell, 147-168. Lanham: Lexington Books.

Avelar, Idelber. 2003. "Heavy Metal Music in Postdictatorial Brazil: Sepultura and the Coding of Nationality in Sound." Journal of Latin American Cultural Studies 12 (3): 329-346.

Avelar, Idelber and Christopher Dunn. 2011. Brazilian Popular Music and Citizenship. Durham: Duke University Press.

Bakhtin, Mikhail. (1935) 2004. "Discourse in the novel." In Literary Theory: An Anthology, edited by Julie Rivkin and Michael Ryan, 674-685. Malden: Blackwell Publishing.

Béhague, Gerard. 2000. "Boundaries and Borders in the Study of Music in Latin America: A Conceptual Re-Mapping." Latin American Music Review 21(1), 1630.

Beausoleil-Morrison, Rachel. 1999. "Montreal Jazz Vocalists: The Relationship Between Their Status and Improvisation, and the Canons of Jazz." M.A., University of Ottawa. 
Benjamin, Walter. (1935) 2004.“The Work of Art in the Age of mechanical Reproduction." In Literary Theory: An Anthology, edited by Julie Rivkin and Michael Ryan, 1235-1241. Malden: Blackwell Publishing.

Bermúdez Cujar, Egberto. 2008. "From Colombian National Song to Colombian Song: 1860-1960." Lied Und Populäre Kultur/Song and Popular Culture: Jahrbuch Des Deutschen Volksliedarchivs Freiburg 53: 167-261.

Biddle, Ian D. and Vanessa Knights. 2007. "National Popular Musics Betwixt and Beyond the Local and Global." In Music, National Identity and the Politics of Location: Between the Global and the Local, edited by Ian D. Biddle and Vanessa Knights, 1-15. Aldershot, England: Ashgate.

Bigenho, Michelle. 2002. Sounding Indigenous: Authenticity in Bolivian Music Performance. New York: Palgrave.

Bohlman, Philip. 2012. "Music and Culture: Historiographies of Disjuncture, Ethnographies of Displacement." In The Cultural Study of Music: A Critical Introduction, $2^{\text {nd }}$ edition, edited by Martin Clayton, Trevor Herbert and Richard Middleton, 28-39. New York: Routledge.

Bourdieu, Pierre. (1979) 2004. “Distinction.” In Literary Theory: An Anthology, edited by Julie Rivkin and Michael Ryan, 237-254. Malden: Blackwell Publishing.

Braga-Pinto, César. 2002. "Supermen and Chiquita Bacana's Daughters. Transgendered Voices in Brazilian Popular Music." In Lusosex, edited by Susan Canty Quinlan and Fernando Arenas, 187-207. Mineapolis: University of Minnesota Press.

Bruner, Michael Lane. 2002. Strategies of Remembrance: The Rhetorical Dimensions of National Identity Construction. Columbia: University of South Carolina Press.

Burdick, John. 2013. The Color of Sound: Race, Religion and Music in Brazil. New York: New York University Press.

Burns, Lori and M. Lafrance. 2002. Disruptive Divas. Feminism, Identity and Popular Music. New York: Routledge.

Burns, Lori and Jada Watson. 2009. "Spectacle and Intimacy in Live Concert Film: Lyrics, Music, Staging, and Film Mediation in P!nk's Funhouse Tour." Music, Sound, and the Moving Image, 7 (2): 103-140. 
Burns, Lori and M. Lafrance. 2017. "Gender, Sexuality And The Politics Of Looking In Beyoncé's 'Video Phone' (Featuring Lady Gaga)." In The Routledge Research Companion to Popular Music and Gender, edited by Stan Hawkins, 102-116. New York: Routledge.

Carvalho, Doug. n.d. Cantoras do Brasil (website). http://www.cantorasdobrasil.com.br. Accessed on September 23, 2017.

Castro, Ruy. (1990) 2000. Bossa Nova: The Story of the Brazilian Music that Seduced the World. Translated by Lysa Salsbury. Chicago: Chicago Review Press.

Castro-Klaren, Sara and John Charles Chasteen, eds. 2003. Beyond Imagined Communities. Reading and Writing the Nation in Nineteenth Century Latin America. Washington, D.C.: Woodrow Wilson Centre Press.

Cavalcanti, Luciano M. Dias. 2011. "Música popular e poesia no Brasil: um breve percurso histórico" (Popular Music and Poetry in Brazil: a Brief Historical Survey). Darandina Revistelectrônica (website), Programa de pos-graduação em letras, Universidade Federal de Juiz de Fora, 4 (1): 1-24. http://www.ufff.br/darandina/files/2011/06/Música-popular-e-poesia-noBrasil-um-breve-percurso-histórico.pdf.

Cavarero, Adriana. 2005. For More Than One Voice. Translated by Paul Kottman. Stanford: Stanford University Press.

Cepeda, Maria Elena. 2010. Musical imagiNation : U.S.-Colombian Identity and the Latin Music Boom. New York: New York University Press.

Cespedés, Gilka Wara. 1993. "Huayno, Saya, and Chuntunqui: Bolivian Identity in the Music of Los Kjarkas." Latin American Music Review 14 (1): 52-101.

Chasteen, John Charles. 2004. National Rhythms, African Roots. The Deep History of Latin American Popular Dance. Albuquerque: University of New Mexico Press.

Chasteen, John Charles. 2012 (2000). "Black Kings, Black Face Carnival, and Nineteenth-Century Origins of Tango." In Latin American Popular Culture since Independence: An Introduction, edited by William H. Beezley and Linda Ann Curcio, 2nd ed., 52-67. Lanham: Rowman \& Littlefield.

Citron, Marcia. 1993. Gender and the Musical Canon. Cambridge: Cambridge University Press.

Coakley, John. 2012. Nationalism, Ethnicity and the State: Making and Breaking Nations. London: Sage Publications.

Collins, Patricia Hill and Sirma Bilge. 2016. Intersectionality. Malden, MA: Polity. 
Connell, John and Chris Gibson. 2003. Sound Tracks: Popular Music, Identity and Place. New York: Routledge.

Cook, Nicholas. 2012. "Music as Performance." In The Cultural Study of Music: A Critical Introduction, $2^{\text {nd }}$ edition, edited by Martin Clayton, Trevor Herbert and Richard Middleton, 184-194. New York: Routledge.

Corona, Ignacio and Alejandro L. Madrid-González, eds. 2008. Postnational Musical Identities: Cultural Production, Distribution, and Consumption in a Globalized Scenario. Lanham: Lexington Books.

Dahl, Linda. (1984) 1996. Stormy Weather: The Music and Lives of a Century of Jazzwomen. New York: Limelight Editions.

Dahlhaus, Carl. 1989. Nineteenth-Century Music. Translated by J. Bradford Robinson. Berkeley: University of California Press.

Davis, Darién J. 2009. White Face Black Mask; Africaneity and the Early Social History of Popular Music in Brazil. East Lansing, Michigan: Michigan State University Press.

Davis, Darién J. 2012. "Racial parity and national humor: Carmen Miranda's samba performances, 1930-1939." In Latin American Popular Culture, edited by William H. Beezley and Linda A. Curcio-Nagy, 176-192. Lanham: Rowman \& Littlefield.

Dennis, Christopher. 2008. "The "Afro-Colombianization" of Hip-Hop and Discourses on Authenticity." In Postnational Musical Identities: Cultural Production, Distribution, and Consumption in a Globalized Scenario, edited by Ignacio Corona and Alejandro L. Madrid-González, 185-207. Lanham: Lexington Books.

Discogs. 2017. "Fabiana Cozza - Canto Sagrado (Uma homenagem a Clara Nunes)" (website). https://www.discogs.com/Fabiana-Cozza-Canto-Sagrado-UmaHomenagem-A-Clara-Nunes/release/7411340.

Dixon, Kwame and John Burdick. 2012. Comparative Perspectives on Afro-Latin America. Gainesville: University Press of Florida.

Dunn, Christopher. 2001. Brutality Garden: Tropicália and the Emergence of a Brazilian Counterculture. Chapel Hill: University of North Carolina Press.

Encyclopedia Brittanica. 2017. “Modinha: Portuguese Song Genre.” (website) https://www.britannica.com/art/modinha. 
Enriquez, Falina. 2012. "The Ins and Outs of Cultura: How Bands Voice their Relationships to the State-Sponsored Music Scene in Recife, Brazil." Journal of Popular Music Studies 24 (4): 532-553.

Espaço Musical. n.d. "Institutional” (website). Accessed on Feb. 14, 2017 https://www.espacomusical.com.br.

Faleiros, Álvaro. 2013. "The new Brazilian Popular Music." Presented at the Panamérica Canção (Panamerican Song) Project Symposium at Carleton University, Sponsored by the Universidade de São Paulo (University of São Paulo), Ottawa, March 22, 2013.

Fausto, Boris and Sergio Fausto. (1999) 2014. A Concise History of Brazil. $2^{\text {nd }}$ ed. Translated by Arthur Brakel. New York: Cambridge University Press.

Feldman, Heidi Carolyn. 2012. "Strategies of the Black Pacific. Music and Diasporic Identity in Peru." In Dixon, Kwame and John Burdick. Comparative Perspectives on Afro-Latin America, edited by Kwame Dixon and John Burdick, 4271. Gainesville: University Press of Florida.

Frith, Simon. 1996. Performing Rites: Evaluating Popular Music. Cambridge: Harvard University Press.

Frota, Wander Nunes. 2000. "A Geração Noel Rosa e o Samba Como Símbolo Nacional: Fronteiras Da Industria Cultural Carioca Nos Anos 20 e 30; Polos Diferenciais Na Historia Brasileira Da Música Popular" (The Noel Rosa Generation and the Samba as a National Symbol: Boundaries of the Rio Cultural Industry in the 1920s and 30s; Polar Opposites in Brazilian Popular Music History). Ph.D., University of Minnesota.

Fryer, Peter. 2000. Rhythms of Resistance: African Musical Heritage in Brazil. Hanover: Wesleyan University Press; University Press of New England.

Galletta, Thiago. 2016. Cena musical paulistana dos anos 2010: a "música brasileira" depois da Internet (The São Paulo scene of the 2010s: "Brazilian music" after the Internet). São Paulo: Annablume.

Gates, Henry Louis. 1988. The Signifying Monkey: A Theory of African-American Literary Criticism. New York: Oxford University Press.

G1 Globo. 2012. "Morre Dona Canô, aos 105 anos, diz filho em Santo Amaro, na Bahia" (Dona Canô dies, at 105 years of age, says her son in Santo Amaro, in Bahia). Bahia (website). Last modified December 25, 2012. http://g1.globo.com/bahia/noticia/2012/12/morre-dona-cano-aos-105anos-diz-filho-em-santo-amaro-na-bahia.html. 
Galinsky, Philip. 2002. "Music and Place in the Brazilian Popular Imagination. The Interplay of Local and Global in the Mangue Bit Movement of Recife, Pernambuco, Brazil." In From Tejano to Tango: Latin American Popular Music, edited by Walter A. Clark, 195-216. New York: Routledge.

Gates, Henry Louis. 1988. The Signifying Monkey: A Theory of African-American Literary Criticism. New York: Oxford University Press.

Garramuño, Florencia. 2011. Primitive Modernities: Tango, Samba, and Nation. Translated by Anna Kazumi Stahl. Stanford, California: Stanford University Press.

Gioia, Ted. 1997. The History of Jazz. New York: Oxford University Press.

Goldschmitt, Kariann. 2011. "Doing the Bossa Nova: The Curious Life of a Social Dance in 1960s North America." Luso-Brazilian Review 48 (1): 61-78.

Gough, David. 2015. “Listening In The Megacity:?Music In São Paulo’s Cultural Policy Worlds.” Ph.D., University of Chicago.

Gracyk, Theodore. 2007. Listening to Popular Music. Or, How I learned to Stop Worrying and Love Led Zeppelin. Ann Arbor: University of Michigan Press.

Green, Lucy. 2012. "Music Education, Cultural Capital, and Social Group Identity." In The Cultural Study of Music: A Critical Introduction, $2^{\text {nd }}$ edition, edited by Martin Clayton, Trevor Herbert and Richard Middleton, 184-194. New York: Routledge.

Guilbault, Jocelyne. 2006. "On Redefining the 'Local' through World Music." In Ethnomusicology: A Contemporary Reader, edited by Jennifer C. Post, 137-146. New York: Routledge.

Henry, Clarence Bernard. 2008. Let's Make Some Noise: Axé and the African Roots of Brazilian Popular Music. Jackson: University Press of Mississippi.

UniCamp. n.d. Instituto de artes (website) Accessed Feb. 14, 2017. http://www.iar.unicamp.br/graduacao-em-musica.

Jones, Carys Wyn. 2008. The Rock Canon: Canonical Values in the Reception of Rock Albums. Burlington, VT: Ashgate.

Karppinen, Anne. 2016. Songs of Joni Mitchell: Gender, Performance and Agency. New York: Routledge.

Loomba, Ania. (1998) 2005. Colonialism/Postcolonialism. $2^{\text {nd }}$ ed. New York: Routledge. 
Luciana Souza. n.d. "Bio English” (website). Accessed on Feb. 14, 2017 http://www.lucianasouza.com/pdfs/bio english souza.pdf.

Machado, Regina. 2011. A voz na canção brasileira: um estudo sobre a Vanguarda Paulista (The Voice in Brazilian Song: a Study on the Paulista Vanguard). Cotia, São Paulo: Ateliê Editorial.

Machado, Regina. 2012. “Da intenção ao gesto interpretativo: análise semiótica do canto popular brasileiro" (From Intention to Interpretive Gesture: Semiotic Analysis of Brazilian Popular Song.) Ph.D., Universidade de São Paulo, Brazil.

Magaldi, Christina. 2008. "Before and After Samba: Modernity, Cosmopolitanism, and Popular Music in Rio de Janeiro at the Beginning and end of the Twentieth Century." In Postnational Musical Identities: Cultural Production, Distribution, and Consumption in a Globalized Scenario, edited by Ignacio Corona and Alejandro L. Madrid-González, 173-184. Lanham: Lexington Books.

Manuel, Peter. 2000. "Ethnic Identity, National Identity, and Music in IndoCaribbean Culture." In Music and the Racial Imagination, edited by Philip Vilas Bohlman and Ronald Michael Radano, 318-345. Chicago: University of Chicago Press.

McCann, Bryan. 2004. Hello, Hello Brazil: Popular Music in the Making of Modern Brazil. Durham: Duke University Press.

McClary, Susan. 1991. Feminine Endings: Music, Gender and Sexuality. Minnesota: University of Minnesota Press.

Middleton, Richard. 2000. "Work-in-(g) Practice: Configuration of the Popular Music Intertext." In The Musical Work: Reality or Invention?, edited by Michael Talbot, 59-87. Liverpool: Liverpool Music Symposium.

Moehn, Frederick. 2007. "Music, Citizenship, and Violence in Postdictatorship Brazil." Latin American Music review 28 (2): 181-219.

Moy, Ron. 2015. Authorship Roles in Popular Music: Issues and Debates. New York: Routledge.

Neustadt, Robert. 2011. "Reading Spanish American National Anthems: Sonograms of National Identity." Music and Politics 5 (1): 19 p. http://www.music.ucsb.edu/projects/musicandpolitics/archive/20111/neustadt.html. Accessed on January 20, 2014.

O’Flynn, John. 2007. "National Identity and Music in Transition: Issues of Authenticity in a Global Setting." In Music, National Identity and the Politics of 
Location: Between the Global and the Local, edited by Ian D. Biddle and Vanessa Knights. Aldershot, England: Ashgate.

Oxford English. 2017. Oxford Living Dictionaries. (website) https://en.oxforddictionaries.com/definition/canon.

Packman, Jeff. 2011. "Musicians' Performances and Performances of "Musician" in Salvador Da Bahia, Brazil." Ethnomusicology 55 (3): 414-444.

Packman, Jeff. 2009. "Signifyin(g) Salvador: Professional Musicians and the Sound of Flexibility in Bahia, Brazil's Popular Music Scenes." Black Music Research Journal 29 (1): 83-126.

Party, Daniel. 2008. “The Miamization of Latin-American Pop Music." In Postnational Musical Identities: Cultural Production, Distribution, and Consumption in a Globalized Scenario, edited by Ignacio Corona and Alejandro L. MadridGonzález, 65-80. Lanham: Lexington Books.

Perrone, Charles A. and Christopher Dunn, eds. (2001) 2002. Brazilian Popular Music \& Globalization. Gainesville: University Press of Florida.

Post, Jennifer C. 1994. "Erasing the Boundaries between Public and Private in Women's Performance Traditions." In Cecilia Reclaimed: Feminist Perspectives on Gender and Music, edited by Susan C. Cook and Judy S. Tsou, 35-51. Chicago: University of Illinois Press.

Prado, Bruna Queiroz. 2016. “Cantores e músicos: uma reflexão sobre gênero e profissão a partir de Maria Bethânia" (Singers and musicians: a reflection on gender and profession after Maria Bethânia). Paper presented at the XXVI Congresso da Associação Nacional de Pesquisa e Pós-Graduação em Música $\left(26^{\text {th }}\right.$ Congress of the National Association of Graduate Studies and Research in Music), Belo Horizonte, September 2016.

Radano, Ronald. 2012. "Music, Race, and the Fields of Public Culture." In The Cultural Study of Music: A Critical Introduction, $2^{\text {nd }}$ edition, edited by Martin Clayton, Trevor Herbert and Richard Middleton, 308-316. New York: Routledge.

Recording Academy. 2017. “Artist Luciana Souza.” (website) Last modified 2017. https://www.grammy.com/grammys/artists/luciana-souza.

Reily, Suzel Ana. 2000. "Introduction: Brazilian Musics, Brazilian Identities." British Journal of Ethnomusicology 9 (1): 1-10.

Rocha, Fernando de Sousa. 2012. "Recovering Voices: The Popular Music Ear in Late Nineteenth- and Early Twentieth-Century Brazil." In Media, Sound, \& Culture in 
Latin America and the Caribbean, edited by Alejandra Bronfman and Andrew Grant Wood, 3-17. Pittsburgh: University of Pittsburgh Press.

Rustin, Nichole T. and Sherrie Tucker. 2008. Big Ears: Listening for Gender in Jazz Studies. Durham: Duke University Press.

Sandroni, Carlos. 2011. “Farewell to MPB.” In Brazilian Popular Music and Citizenship, edited by Idelber Avelar and Christopher Dunn, 64-73. Durham: Duke University Press.

Santhiago, Ricardo. 2011. "The Dissonant Lives of Brazilian Black Women NonSamba Singers." Oral History 39 (2): 49-62.

SESC Brasil. 2017. "Vozes que interpretam o Brasil" (Voices that interpret Brazil). SESC São Paulo (website). Last modified 2017. https://www.sescsp.org.br/online/artigo/10401 VOZES+QUE+INTERPRETA M+O+BRASIL.

Severiano, Jairo. 2013 (2008). Uma história da música popular brasileira, das origens à modernidade. São Paulo: Editora 34.

Sharp, Dan. 2011. "Performing the Migrant, Performing Home: Televised Nostalgia in Northeast Brazil." Latin American Music Review 32 (2): 181-204.

Silveira, Wilson. 2010. "Mudança do horário da hora do Brasil divide opiniões." Observatório do direito a comunicação, Intervozes (website). Last modified August 24, 2010. http://www.intervozes.org.br/direitoacomunicacao/?p=24859.

Stanbridge, Alan. 2000. "Who Could Ask For Anything More?: Cultural Theory, Contemporary Music, and the Question of Canons." Ph.D., Carleton University, Ottawa.

Sterling, Cheryl. 2012. African Roots, Brazilian Rites: Cultural and National Identity in Brazil. New York: Palgrave Macmillan.

Strohm, Reinhard. 2000. "Looking Back At Ourselves: The Problem with the Musical Work-Concept.” In The Musical Work: Reality or Invention?, edited by Michael Talbot, 128-152. Liverpool: Liverpool Music Symposium.

Stroud, Sean. 2006. “Marcus Pereira's 'Música Popular do Brasil’: Beyond Folklore?” Popular Music 25 (2), 303-318.

Stroud, Sean. 2008. The Defence of Tradition in Brazilian Popular Music: Politics, Culture and the Creation of Musica Popular Brasileira. Hampshire: Ashgate. 
Talbot, Michael. 2000. "The Work-concept and Composer-Centredness." In The Musical Work: Reality or Invention?, edited by Michael Talbot, 168-186. Liverpool: Liverpool Music Symposium.

Tatit, Luiz. 2004. O Século da Canção (The Century of Song). São Paulo: Ateliê Editorial.

Tinhorão, José Ramos. (1974, 1975, 1978, 1978, 1986, 1991) 2013. Pequena história da música popular segundo seus gêneros (Little History of Popular Music According to Its Genres). $7^{\text {th }}$ ed. São Paulo: Editora 34.

Tomlinson, Gary. 2012. In The Cultural Study of Music: A Critical Introduction, $2^{\text {nd }}$ edition, edited by Martin Clayton, Trevor Herbert and Richard Middleton, 5972. New York: Routledge.

Turino, Thomas. 2003. "Nationalism and Latin American Music: Selected Case Studies and Theoretical Considerations." Latin American Music Review 24 (2): 169-209.

Ulhôa, Martha Tupinambá de. 1995. "Tupi or Not Tupi MPB: Popular Music and Identity in Brazil." In The Brazilian Puzzle: Culture on the Borderlands of the Western World, edited by David Hess and Roberto A. DaMatta, 159-179. New York: Columbia University Press.

UniCamp. n.d. Instituto de Artes. (website) http://www.iar.unicamp.br/graduacaoem-musica. Accessed Feb. 14, 2017.

Vianna, Hermano. (1995) 1999. The Mystery of Samba: Popular Music and National Identity in Brazil. Edited and translated by John Charles Chasteen. Chapel Hill: University of North Carolina Press.

Vianna, Heraldo Marelim. (1996) "Access to Higher Education: Current Issues in Brazil." In Brazilian Issues on Education, Gender and Race, edited by Elba Siqueira de Sá Barretto and Dagmar M.L. Zibas, translated by Jonathan Hannay, 183-188. São Paulo: The Carlos Chagas Foundation.

Waxer, Lise. 2002. The City of Musical Memory: Salsa, Record Grooves, and Popular Culture in Cali, Colombia. Middletown: Wesleyan University Press.

Weidman, Amanda. 2014. "Anthropology and Voice." Annual Review of Anthropology 43: 37-51.

Wood, Elizabeth. (1994) 2006. "Sapphonics." In Queering the Pitch: The New Gay and Lesbian Musicology. $2^{\text {nd }}$ ed. Edited by Philip Brett, Elizabeth Wood and Gary C. Thomas, 27-66. New York: Routledge. 
Wong, Ketty. 2011. "The Song of the National Soul: Ecuadorian Pasillo in the Twentieth Century." Latin American Music Review 32 (1): 59-87. 